Universidade de São Paulo

Faculdade de Medicina de Ribeirão Preto

"Os genes codificadores de glutationa S-transferases na abelha Apis mellifera: expressão, regulação e função durante e após a metamorfose" 
Os genes codificadores de glutationa S-transferases na abelha Apis mellifera: expressão, regulação e função durante e após a metamorfose

Dissertação apresentada à Faculdade de Medicina de Ribeirão Preto da Universidade de São Paulo para a obtenção do título de Mestre.

Área de concentração: GENÉTICA

Orientadora: Profa. Dra. Márcia Maria Gentile Bitondi 
Autorizo a reprodução ou divulgação total ou parcial deste trabalho, por qualquer meio convencional ou eletrônico, para fins de estudo ou pesquisa, desde que citada a fonte.

Loterio, Guaracini Aparecida

Os genes codificadores de glutationa S-transferases na abelha Apis mellifera: expressão, regulação e função durante e após a metamorfose. Ribeirão Preto, 2011.

93 p. : il. ; $30 \mathrm{~cm}$

Dissertação de Mestrado, apresentada à Faculdade de Medicina de Ribeirão Preto/USP. Área de concentração: Genética.

Orientador(a): Bitondi, Márcia Maria Gentile.

1. Apis mellifera 2. Glutationa S-transferases 3. Gene $h p 19$

4. Metamorfose 5. Hexamerinas 
Nome: LOTERIO, Guaracini Aparecida

Título: Os genes codificadores de glutationa S-transferases na abelha Apis mellifera: expressão, regulação e função durante e após a metamorfose

Dissertação apresentada à Faculdade de Medicina de Ribeirão Preto da Universidade de São Paulo para obtenção do título de Mestre.

Aprovado em:

\section{Banca Examinadora}

Prof(a). Dr(a).:

Instituição:

Parecer:

Assinatura:

$\operatorname{Prof}(\mathrm{a}) . \operatorname{Dr}(\mathrm{a})$ :

Instituição:

Parecer:

Assinatura:

Prof(a). Dr(a).:

Instituição:

Parecer:

Assinatura:

Ribeirão Preto, de de 2011. 
"Os obstáculos não podem te deter. Os problemas não podem te deter. Mais que tudo, outras pessoas não podem te deter. Somente você pode deter a si mesmo"

Jeffrey Gitomer

Aos meus pais Dirceu e Solange, à minha irmã Guaraciara que sempre me apoiaram,

E ao meu amor, Rafael Gonçalves

Dedico... 


\section{Agradecimentos}

À Professora Doutora Márcia Maria Gentile Bitondi, um exemplo de profissionalismo, dedicação e paciência, pela orientação, ensinamentos e confiança depositada em meu trabalho. Pela compreensão, amizade e carinho em momentos difíceis;

À Doutoranda e amiga Juliana Ramos Martins, por todos os ensinamentos, pela convivência, conselhos, apoio e orientações indispensáveis para o desenvolvimento deste trabalho;

À Professora Doutora Zilá Luz Paulino Simões pela convivência harmoniosa, conselhos e incrível apoio;

À Vera Lúcia C. Figueiredo, pessoa fundamental para o funcionamento do laboratório, pela ajuda em vários momentos e pelos momentos de distração;

Ao Luiz R. Aguiar, pelo apoio técnico no apiário experimental e pelas longas conversas;

A todos os professores e funcionários do departamento de Genética da Faculdade de Medicina de Ribeirão Preto e do Departamento de Biologia da Faculdade de Filosofia, Ciências e Letras de Ribeirão Preto pela contribuição para minha formação e aprimoramento e pela convivência;

Aos companheiros do Laboratório de Biologia do Desenvolvimento de Abelhas (LBDA) e do Departamento de Genética - Bloco A, pelas sugestões, convivência, incentivo, apoio, ensinamentos. Principalmente ao Rodrigo Pires Dallacqua e Karina R. Guidugli, que me ensinaram muitas coisas e sempre estiveram dispostos a ajudar;

Ao Conselho Nacional de Desenvolvimento Científico e Tecnológico $(\mathrm{CNPq})$ e à Fundação de Amparo à Pesquisa do Estado de São Paulo (FAPESP), pelo apoio através das bolsas concedidas;

Aos meus pais, Dirceu e Solange, que possibilitaram tudo isso, pelo amor, dedicação, apoio, paciência, ensinamentos e por sempre confiarem, acreditarem e me incentivarem a continuar caminhando, seja pelo mesmo caminho ou por outros;

À minha irmã, Guaraciara pelas conversas, apoio e momentos de sentimentos compartilhados; 
Ao meu namorado, Rafael Gonçalves, pela incrível paciência durante o desenvolvimento deste trabalho, pela ajuda, por ouvir meus "desabafos", por me incentivar, confiar, compreender, pelo carinho, amor e por vivenciar esta conquista comigo;

Às minhas amigas "BdBenses" e a minha amiga e cunhada Mayara, pelos momentos vividos juntos, pelas longas conversas, pelas reflexões, por cederem o ombro em momentos tristes, pelas famílias compartilhadas em Ribeirão Preto, pelo carinho, pela diversão, pela sincera e eterna amizade;

Enfim, agradeço a todos que contribuíram de alguma forma na elaboração deste trabalho de mestrado e que em algum momento passaram pela minha vida e contribuíram para minha formação pessoal ou profissional... 
RESUMO 


\section{Resumo}

Loterio, G. A. Os genes codificadores de glutationa S-transferases na abelha Apis mellifera: expressão, regulação e função durante e após a metamorfose. 2011. 93p. Dissertação de Mestrado - Departamento de Genética, Faculdade de Medicina de Ribeirão Preto, Universidade de São Paulo, Ribeirão Preto, 2011.

Em insetos, as enzimas glutationa S-transferases (GSTs) são conhecidas pela capacidade de degradar inseticidas, pesticidas e outros compostos químicos, naturais ou não naturais, estranhos ao organismo, podendo também promover o transporte intracelular de hormônios, metabólitos, e atuar na proteção celular contra o estresse oxidativo. Além disto, a função de uma GST tem sido associada ao processo de sequestro, pelo corpo gorduroso, de um tipo de proteína (hexamerinas) estocada na hemolinfa larval para ser utilizada como fonte de aminoácidos durante a metamorfose. Os objetivos deste trabalho consistiram em caracterizar a estrutura, a expressão e aspectos da função dos genes codificadores de GSTs em abelhas operárias Apis mellifera, além de investigar a possível função de um destes genes, hp191(GSTS1), na dinâmica de sequestro de hexamerinas durante a metamorfose. A metodologia utilizada abrangeu técnicas de biologia molecular, como RT-PCR semiquantitativa e em tempo real, sequenciamento de nucleotídeos, western blot, silenciamento gênico. Resumidamente os resultados mostraram (1) diferenças estruturais (número e organização de íntrons e éxons) entre os dez genes GSTs de A. mellifera, (2) aumento da atividade destes genes relacionado ao envelhecimento e intensa atividade de forrageamento, (3) níveis de expressão dependente do tipo de dieta alimentar, (4) perfil de expressão de $h p 19^{1}$ (GSTS1), assim como sua resposta aos hormônios morfogenéticos (hormônio juvenil e 20-hidroxiecdisona), consistentes com função na metamorfose, (4) diminuição dos níveis de hexamerina HEX 70a na hemolinfa em consequência do silenciamento de $h p 19^{1}$ (GSTS1) mediado por RNAi. Em conjunto, estes dados informam sobre estrutura, expressão e função dos genes GSTs de A. mellifera com particular foco na potencial participação de $h p 19^{1}$ (GSTS1) na metamorfose.

Palavras-chave: Apis mellifera, Glutationa S-transferases, Gene hp19, Metamorfose, Hexamerinas. 


\begin{abstract}
Loterio, G. A. The genes encoding glutathione S-transferases in the honeybee (Apis mellifera): expression, regulation and function during and after metamorphosis. 2011. 93p. MSc Dissertation - Genetics Department, Faculdade de Medicina de Ribeirão Preto, Universidade de São Paulo, Ribeirão Preto, 2011.
\end{abstract}

In insects, the enzymes glutathione S-transferases (GSTs) are known for their ability to degrade insecticides, pesticides and other chemical compounds, natural or not, which are not normally produced or expected to be present in the organism. GSTs can also promote the intracellular transportation of hormones and metabolites as well as act in the cellular protection against oxidative stress. In addition, the GST function has been associated with the process of sequestration, by the fat body, of one type of protein (hexamerin) which is stored in the larval hemolymph to be used as a source of amino acids during metamorphosis. The aims of this study were (1) to characterize structure and expression, and explore the roles of the GST encoding genes in Apis mellifera worker bees and, (2) to investigate the potential role of one of these genes, $h p 19^{1}$ (GSTS1), in the dynamics of hexamerin sequestration during metamorphosis. The methodology included molecular biology techniques, such as semiquantitative and real time RT-PCR, gene sequencing and silencing, and western blot. Briefly, the results revealed structural differences (number and organization of introns and exons) among the ten GSTs genes of A. mellifera, increased activity of these genes associated to bee aging and the intense foraging activity, and modulation of the expression levels of GST genes by the type of diet. The results also revealed that the expression profile of $h p 19^{1}$ (GSTS1), as well as its response to the morphogenetic hormones (juvenile hormone and 20-hydroxyecdysone), are consistent with a function in metamorphosis. Furthermore, hp191(GSTS1) silencing mediated by RNAi resulted in decreased hemolymph levels of a hexamerin (HEX 70a) with an essential function in metamorphosis. Altogether, these data provide novel findings concerning the structure, expression and function of the GSTs genes of A. mellifera with a special focus on the potential participation of $h p 19^{1}$ (GSTS1) in metamorphosis.

Key-words: Apis mellifera, Glutathione S-transferase, hp19 gene, Metamorphosis, Hexamerins. 


\section{Lista de Figuras}

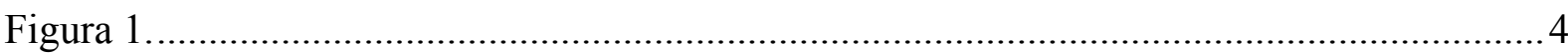

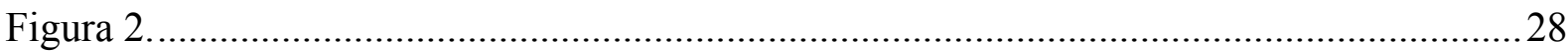

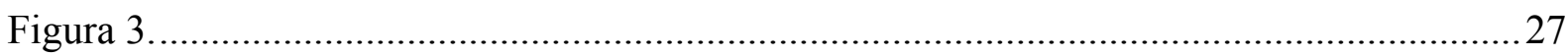

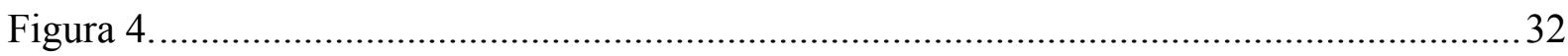

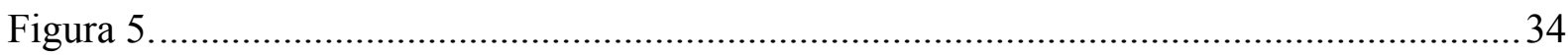

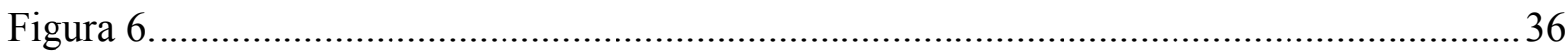

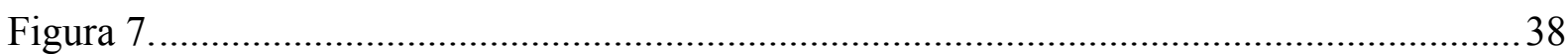

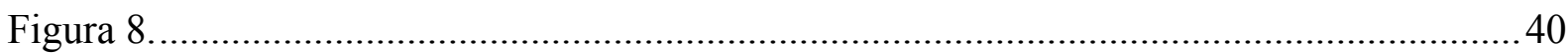

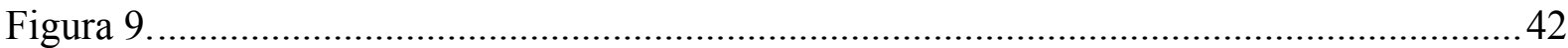

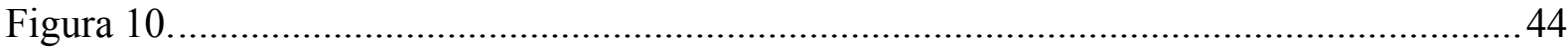

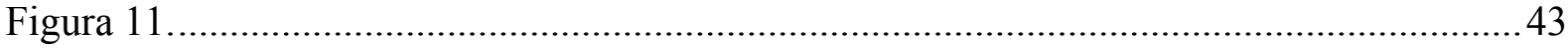

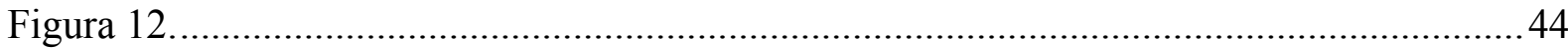

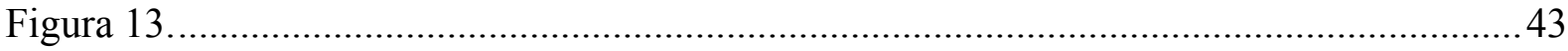

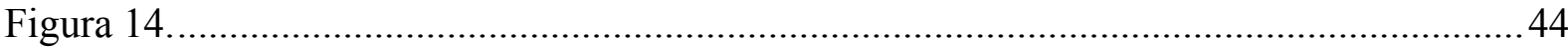

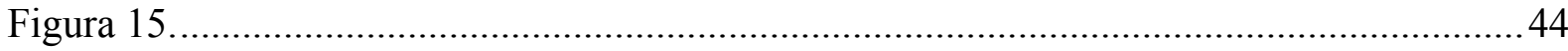

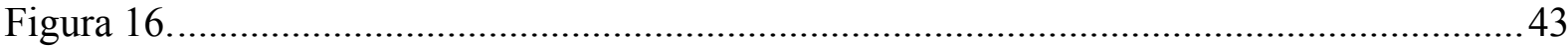

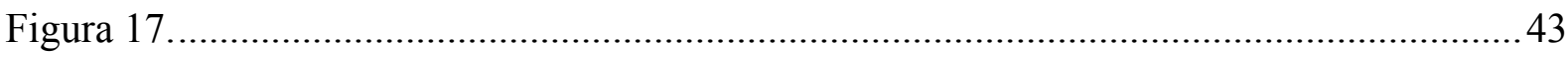

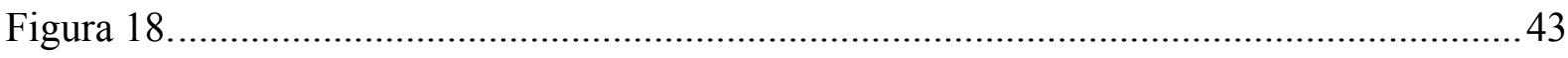

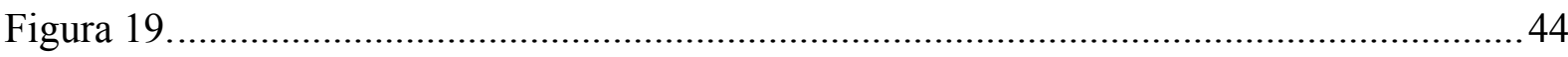

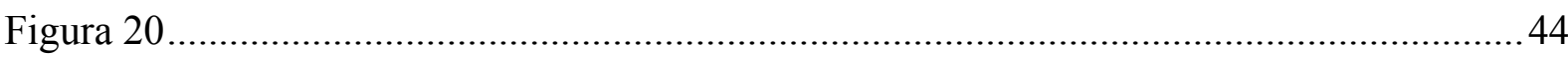

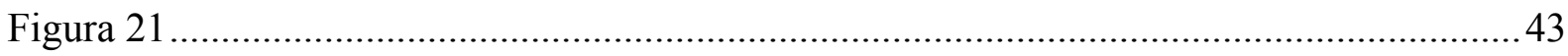

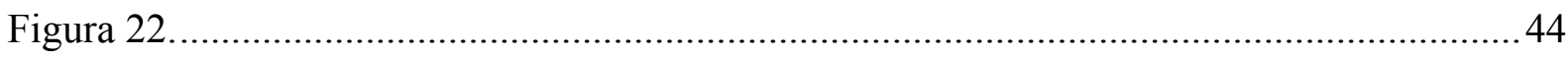

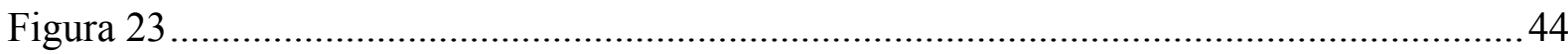

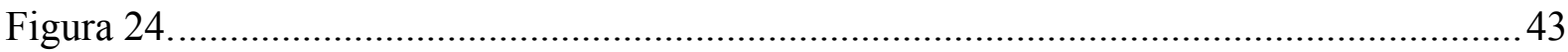

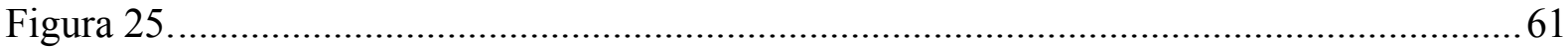




\section{Lista de Tabelas}

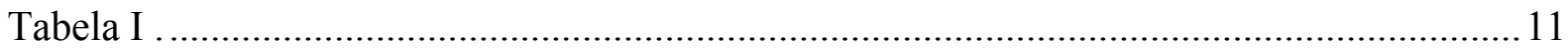

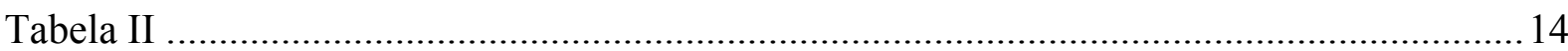

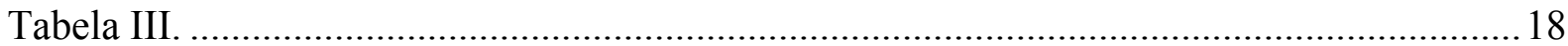




\section{Lista de Abreviaturas e Símbolos}

APS - persulfato de sódio

${ }^{\circ} \mathbf{C}$ - graus Celsius

cDNA - ácido desoxirribonucléico complementar

CDNB - 1-cloro-2,4-dinitrobenzeno

CDS - sequência codificadora

cm - centímetro(s)

DDT - dicloro-difenil-tricloroetano

DNA - ácido desoxirribonucléico

dsRNA - ácido ribonucléico dupla fita

ETH - ecdysis triggering hormanease like proteins

g-grama(s)

GSH - glutationa

GST - glutathione S-transferase

HEX - hexamerina

HJ - hormônio juvenil

HP19 - Hemolymph protein $19 \mathrm{kDa}$

kDa - kilodalton(s)

LD50 - dose letal para 50\% da população em teste

$\mathbf{L}_{4}-4^{\circ}$ instar larval

$\mathbf{L}_{5}-5^{\circ}$ instar larval

$\mathbf{L}_{5} \mathbf{F}$ - $5^{\circ}$ instar larval, fase de alimentação

$\mathbf{L}_{5} \mathbf{S}$ - $5^{\circ}$ instar larval, fase de tecelagem do casulo

M - molar

mg - miligrama(s)

min - minuto(s)

$\mathbf{m L}-$ mililitro(s)

$\mathbf{m M}$ - milimolar(es)

mRNA - ácido ribonucléico mensageiro

nm - nanômetro(s)
$\mathbf{P}$ - pupa

PAGE - eletroforese em gel de poliacrilamida

pb - par(es) de base(s)

$\mathbf{P b}$ - pupa de olho marron

Pbl - pupa de olho marron, pigmentação corporal leve

PCR - reação em cadeia da polimerase

PETH - pré-ecdysis triggering hormone

$\mathbf{P p}$ - pupa de olho rosa claro

PP - prepupa

PPN - pyriproxyfen

PTTH - hormônio protoracicotrópico

Pw - pupa de olho branco

RNA - ácido ribonucléico

ROS - espécies reativas de oxigênio

$\mathbf{r p m}$ - rotações por minuto

RT - transcrição reversa

RT-PCR - transcrição reversa da reação em cadeia

da polimerase

$\mathbf{s}-\operatorname{segundo}(\mathrm{s})$

SDS - dodecil sulfato de sódio

TEMED-N,N,N',N'-tetrametil-etileno-diamina

$\mathbf{U}$ - unidade(s)

$\boldsymbol{\mu g}$ - micrograma(s)

$\boldsymbol{\mu} \mathbf{L}-\operatorname{microlitro}(\mathrm{s})$

$\boldsymbol{\mu} \mathbf{M}-$ micromolar(es)

V - volts

$\boldsymbol{x g}$ - força centrífuga relativa

20E - 20-hidroxiecdisona 


\section{Sumário}

1. INTRODUÇÃ

1.1. Apis mellifera: morfotipos e ontogênese.................................................................. 1

1.2. Envolvimento de uma glutationa S-transferase na utilização de proteínas estocadas na

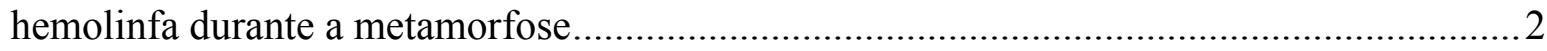

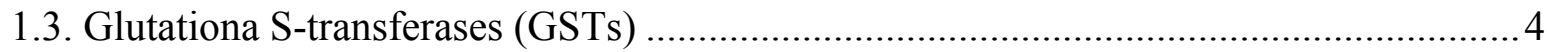

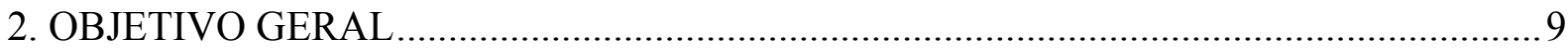

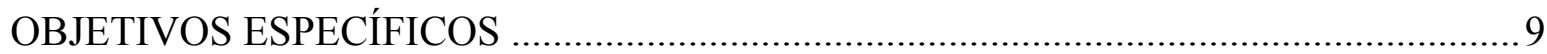

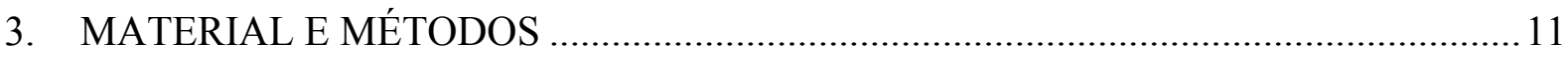

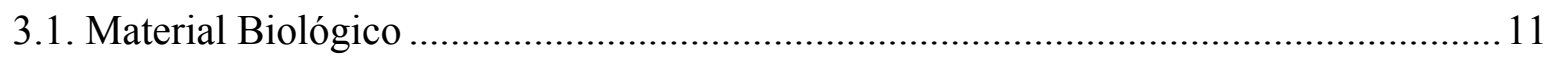

3.1.1. Coleta de abelhas operárias em estágios larval e pupal ........................................ 11

3.1.2. Coleta de abelhas operárias forrageiras e nutridoras............................................ 12

3.1.3. Coleta de abelhas operárias para os experimentos de manipulação da dieta

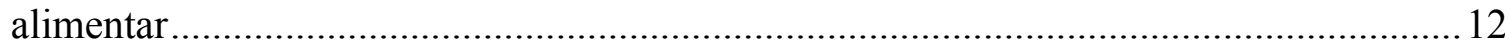

3.1.4. Coleta de abelhas operárias para os experimentos de tratamento com Pyriproxyfen

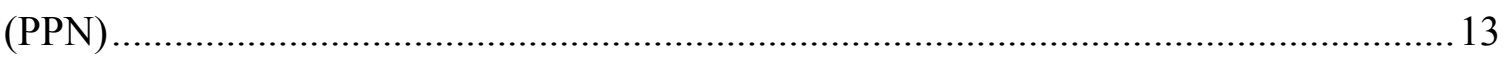

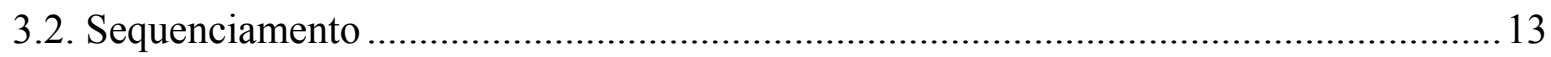

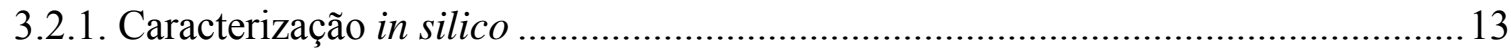

3.2.2. Purificação dos cDNAs amplificados por PCR …................................................ 15

3.2.3. Preparo de células competentes - Escherichia coli linhagem DH5 $\alpha$...................... 15

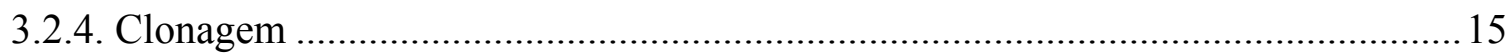

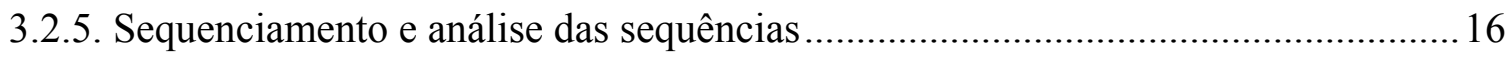

3.2.6. Análise de similaridade e dedução da sequência de nucleotídeos ........................... 16

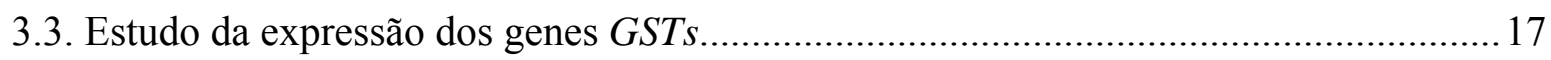

3.3.1. Extração do RNA total e síntese do cDNA ……........................................................ 17

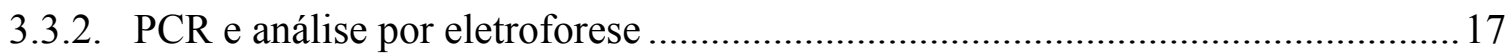

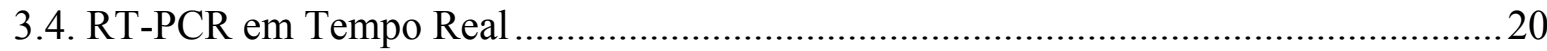

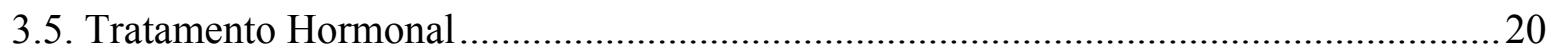

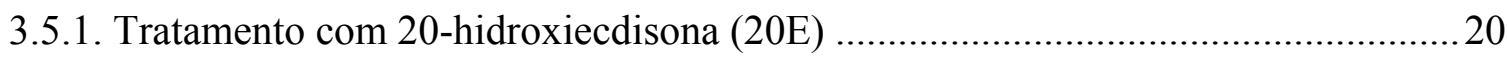

3.5.2. Tratamento com HJ III e pyriproxyfen (PPN) ..................................................... 21

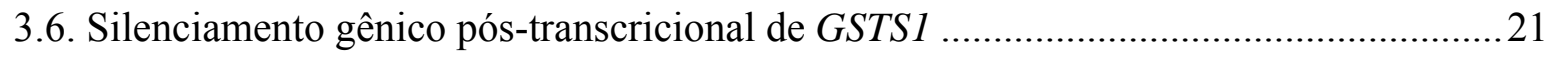

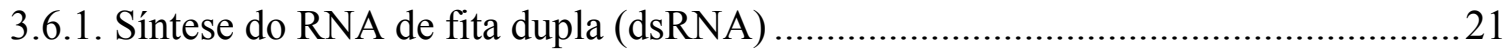


3.6.2. Tratamento de larvas de operárias com dsRNA

3.7. Verificação do teor de hexamerinas HEX 70a na hemolinfa......................................23

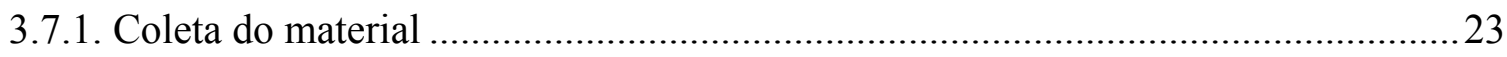

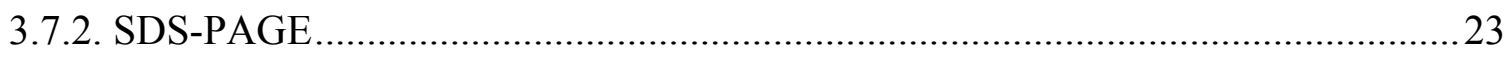

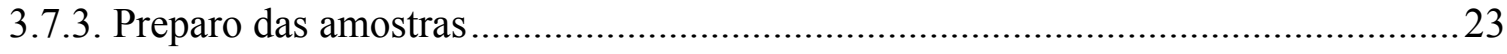

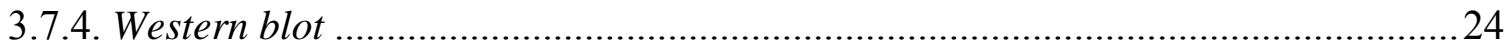

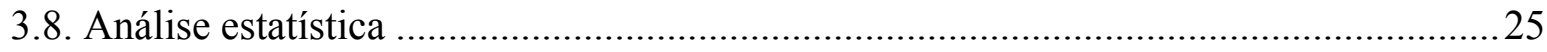

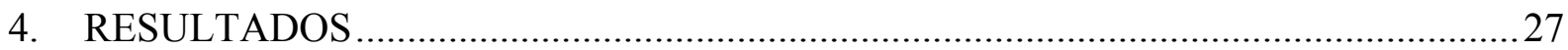

4.1. Sequenciamento e análise dos genes codificadores de GSTs ................................27

4.2. Expressão dos genes codificadores de GSTs ......................................................... 30

4.2.1. Análise da expressão dos genes GSTs em tecidos de operárias forrageiras e

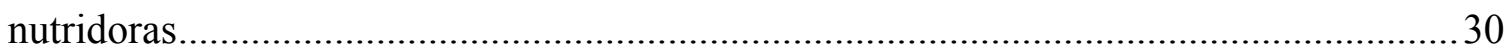

4.2.2. Análise de expressão dos genes GSTs em tecidos de abelhas operárias alimentadas com diferentes dietas 35

4.2.3. Análise de expressão dos genes GSTs em tecidos de abelhas operárias adultas 24 horas após tratamento com PPN

4.2.3.1. Análise de expressão dos genes GSTS2 e GSTmic1 em tecidos de abelhas operárias, decorridos 1, 6 e 11 horas após o tratamento com PPN......

4.3. Busca por genes codificadores de HP19 no genoma de A. mellifera. 44

4.4. Expressão dos genes $h p 19^{1}$ (GSTS1) e $h p 19^{2}$ (GSTS4) em diferentes tecidos e durante o desenvolvimento de $A$. mellifera.

4.5. Efeito de 20E e de PPN na expressão dos genes $h p 19^{1}\left(\right.$ GSTS1) e $h p 19^{2}$ (GSTS4) no intestino posterior de larvas e pupas/adultas-faratas.

4.5.1. Efeito do tratamento hormonal em larvas .......................................................... 44

4.5.2. Efeito do tratamento hormonal em pupas/adultas-faratas ......................................51

4.6. Silenciamento gênico pós-transcricional de $h p 19^{1}$ (GSTS1) ........................................55

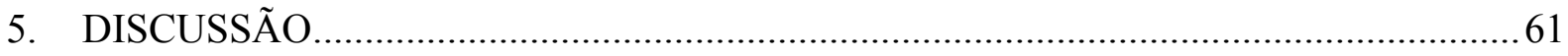

5.1. Sequenciamento e análise dos genes codificadores de GSTs .................................... 61

5.2. Expressão dos genes GSTs em tecidos de operárias forrageiras e nutridoras............61

5.3. Expressão dos genes GSTs em tecidos de operárias alimentadas com diferentes dietas......

5.4. Expressão dos genes GSTs em tecidos de operárias tratadas com PPN 62

5.5. Caracterização e expressão de possíveis ortólogos do gene codificador de uma GST (HP19) de C. cephalonica em A. mellifera. 
5.6. O hormônio 20E induz a expressão dos genes $h p 19^{1}$ (GSTS1) e hp19²(GSTS4)........61

5.7. O HJ induz a expressão de $h p 19^{1}$ (GSTS1), mas não de $h p 19^{2}($ GSTS4) .........................62

5.8. O silenciamento gênico pós-transcricional de $h p 19^{1}$ (GSTS1) causa redução do teor de hexamerina HEX 70a na hemolinfa. .70

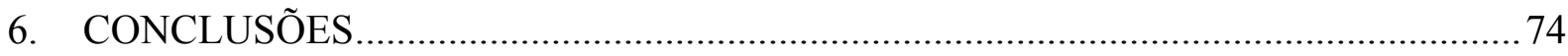

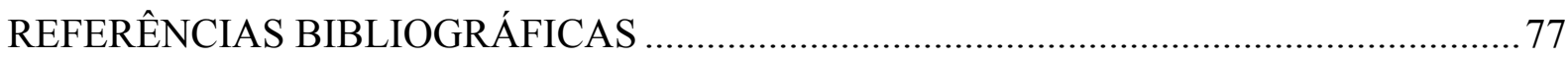

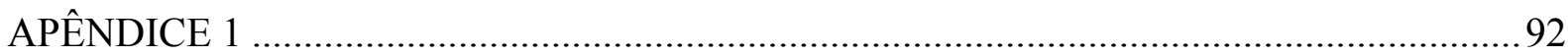

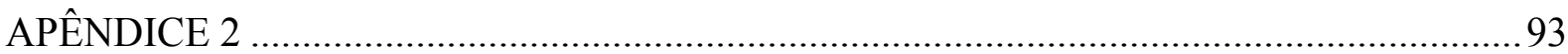


INTRODUÇÃO 


\section{INTRODUÇÃO}

\subsection{Apis mellifera: morfotipos e ontogênese}

Em uma colônia de Apis mellifera (Hymenoptera, Apidae) convivem três formas de abelhas adultas: a fêmea reprodutiva, ou rainha, oriunda de ovos fertilizados e, portanto, diplóides, e que tem como funções principais a reprodução e a síntese e liberação de feromônios para coordenar a fisiologia e o comportamento dos membros da colônia e assim controlar e organizar o modo de vida destes insetos sociais (Le Conte \& Hefetz, 2008); as operárias, fêmeas inférteis, porém com potencial reprodutivo também originadas de ovos fertilizados, diplóides, que desempenham diversas tarefas em ordem cronológica, tais como, limpeza e remoção de cera do ninho, alimentação e cuidado com a prole, construção dos favos, processamento de pólen e néctar para produção do mel, ventilação, proteção da colméia e forrageamento. $\mathrm{O}$ conjunto destas atividades é conhecido como polietismo etário, associado a mudanças fisiológicas e comportamentais (Fluri et al., 1982); os zangões, machos originados em geral por partenogênese a partir de ovos não fertilizados, haplóides, cuja função é fecundar a rainha (Michener, 1969, 1974; Laidlaw, 1992; Jassim et al., 2000; Page \& Peng, 2001; Page \& Erber, 2002).

Em relação ao tipo de desenvolvimento ou ontogenia, as abelhas são insetos holometábolos e como tal passam por metamorfose completa que abrange quatro estágios distintos: embrionário, larval, pupal e adulto. Os embriões se desenvolvem de ovos depositados nos alvéolos de cera dos favos, ou células de cria, construídos pelas abelhas operárias. Após três dias, as larvas eclodem dos ovos e iniciam um período de intensa alimentação, marcado pelo crescimento corporal e aumento do peso, que envolve quatro mudas, ou substituição do rígido exoesqueleto esclerotizado (ou cutícula) por um novo, maior. Quando a larva pára de se alimentar, ela tece o casulo e o alvéolo é fechado pelas operárias. A larva então paulatinamente elimina todo o conteúdo intestinal em preparação para a quinta muda, metamórfica, que transforma a larva em pupa. Em contraste com as sucessivas mudas larvais que não resultam em modificação da forma corporal, mas sim em aumento de tamanho, a muda metamórfica é marcada por uma completa modificação da forma e a pupa exibe a forma do adulto, embora imaturo. Alguns órgãos larvais degeneram por morte celular programada, ocorre a reconstrução da musculatura e do canal alimentar, e o desenvolvimento dos órgãos da reprodução, segue-se a ecdise da cutícula pupal e a síntese da 
cutícula definitiva que caracterizam a sexta e última muda, imaginal, e a abelha adulta finalmente emerge do alvéolo do favo (Snodgrass, 1956; Winston, 2003).

Nos insetos holometábolos em geral, as mudas larvais, metamórfica e imaginal são reguladas por ação de hormônios, entre eles o hormônio protoracicotrópico, o hormônio da eclosão, os hormônios desencadeadores de ecdise, conhecidos como pré-ecdysis triggering hormone e ecdysis triggering hormone (os quais são liberados para ativar circuitos neurais específicos no sistema nervoso central, envolvidos com a regulação dos eventos sequenciais da ecdise), a bursicona, o hormônio juvenil (HJ) e os ecdisteróides, que também participam de diversas funções no ciclo de vida dos insetos (Gilbert, 2006; Davis et al., 2007; Zitnan et al., 2007; Zitnan \& Adams, 2005).

O HJ é sintetizado pelos corpora allata que são um par de glândulas localizadas no complexo retrocerebral, que também inclui as glândulas protorácicas (Gilbert et al., 2000) onde os ecdisteróides são produzidos (Nijhout \& Wheeler, 1982; de Wilde \& Beetsma, 1982; Rembold, 1987b; Rachinsky et al., 1990; Schmidt-Capella \& Hartfelder, 1998). O principal ecdisteróide da hemolinfa de A. mellifera é a makisterona A (Feldlaufer et al., 1985; Rachinsky et al., 1990), embora 20-hidroxiecdisona (20E) seja o principal ecdisteróide da maioria dos insetos (Robinson et al., 1991). O HJ III é o único presente nas abelhas entre todos os tipos de HJ detectados nos insetos (HJ 0, HJ I, HJ II e HJ III, HJ B3, MF) (Trautmann et al., 1974; Huang et al., 1991). Em sinergia com 20E, o HJ garante a muda de um instar larval para o seguinte. Quando o título de HJ decai, e em presença de 20E, a larva muda para pupa.

\subsection{Envolvimento de uma glutationa S-transferase na utilização de proteínas estocadas na hemolinfa durante a metamorfose}

Em insetos holometábolos, a transição do estágio larval para o pupal e o subsequente desenvolvimento do adulto ocorre com base nas reservas de nutrientes acumuladas durante o estágio larval, uma vez que as pupas e adultos-faratos (adultos em desenvolvimento, ainda recobertos pela cutícula pupal) não se alimentam. Proteínas produzidas durante o estágio larval e armazenadas na hemolinfa recebem a denominação geral de "proteínas de estocagem" (Burmester \& Scheller, 1999). Algumas destas pertencem à classe das hexamerinas (Telfer \& Kunkel, 1991) e consistem de seis subunidades similares ou idênticas, em geral de 75-90 kDa (Scheller et al., 1990; Telfer \& Kunkel, 1991). São sintetizadas em grandes quantidades pelo 
corpo gorduroso larval em resposta à intensa ingestão de alimento, e são secretadas na hemolinfa onde se acumulam, podendo perfazer 60 a $90 \%$ do total de proteínas circulantes (Scheller et al., 1990; Haunerland, 1996). Por ocasião da muda metamórfica, inicia-se o sequestro das hexamerinas pelas mesmas células do corpo gorduroso que as sintetizaram e neste órgão elas são então armazenadas em grânulos citoplasmáticos para serem utilizadas em processos do metabolismo intermediário e atender ao desenvolvimento pós-larval (Locke \& Collins 1965, 1966, 1967, 1968; Levenbook \& Bauer, 1984).

Estudos preliminares sugeriram que o sequestro das hexamerinas, e de outras proteínas da hemolinfa, ocorria por meio de um mecanismo de endocitose não-seletivo (Locke \& Collins, 1966; Duhamel \& Kunkel, 1987). No entanto, a seletividade deste processo foi demonstrada pela identificação de receptores de hexamerinas nas membranas das células do corpo gorduroso de espécies de Lepidoptera (Kirankumar et al., 1997; Wang \& Haunerland, 1994) e Diptera (Burmester \& Scheller, 1992, 1999).

A atividade dos receptores de hexamerinas é regulada por 20E (Burmester \& Scheller, 1999). Entretanto, o mecanismo proposto para a ativação destes receptores pode diferir entre os grupos de insetos. Em uma espécie de Diptera, a mosca Calliphora vicina, por exemplo, 20E é o mediador da clivagem que ativará o receptor, promovendo assim o sequestro das hexamerinas (Burmester \& Scheller, 1997). Já em outra espécie de Diptera, Sarcophaga peregrina, 20E previne a clivagem do receptor por proteinases e, dessa forma, o receptor intacto é capaz de promover o sequestro das hexamerinas. (Chung et al., 1995). No Lepidoptera Corcyra cephalonica, o hormônio 20E induz a fosforilação e consequente ativação do receptor por meio de uma tirosina quinase (Arif et al., 2003). Uma proteína da

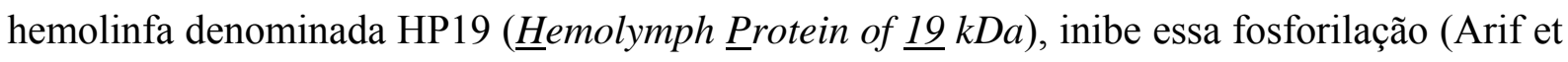
al., 2004). Assim, em larvas de C. cephalonica, quando as taxas de $20 \mathrm{E}$ são baixas, a proteína HP19 inibe a tirosina quinase específica e, consequentemente, a fosforilação do receptor (Dutta-Gupta \& Ashok, 1998). Em consequência, não ocorre o sequestro de hexamerinas pelas células do corpo gorduroso. Durante os estágios pré-pupal (pupa-farata) e pupal, o nível de 20E é elevado e a proteína HP19 está inativa, permitindo assim a fosforilação do receptor e o sequestro de hexamerinas (Arif et al., 2008) (Fig. 1). 

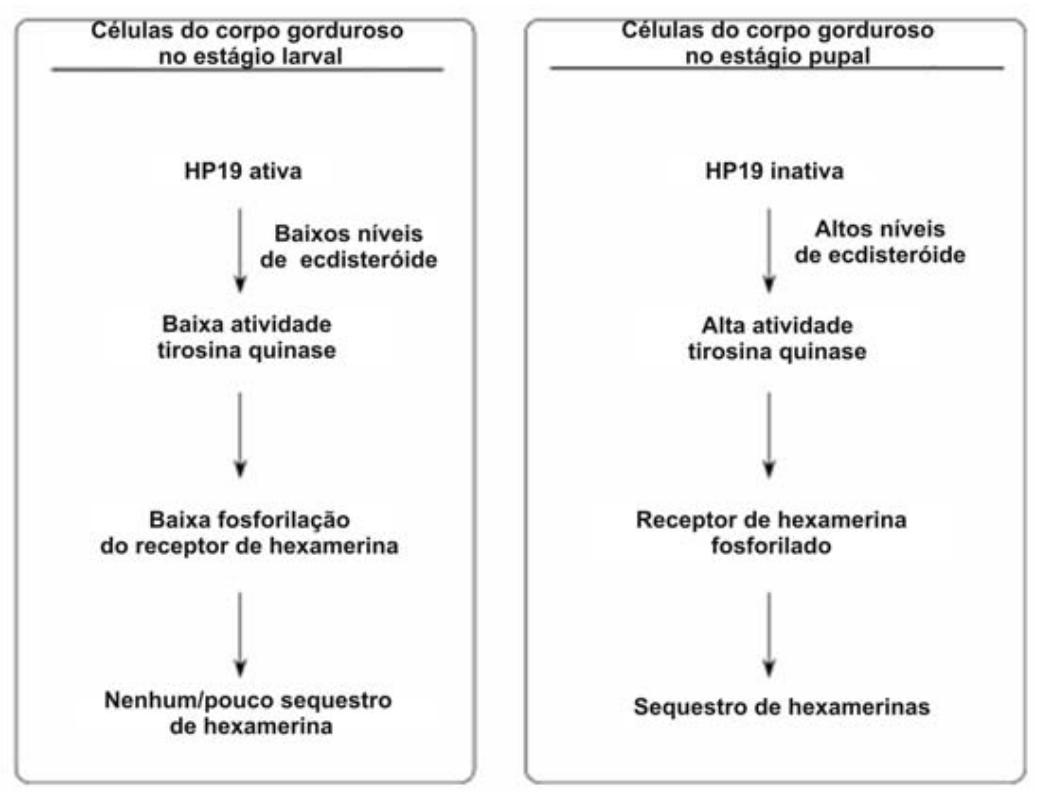

A proteína HP19 identificada em C. cephalonica existe como um monômero. O sequenciamento desta proteína revelou que pertence à família GST-like (glutathione-Stransferase like proteins), mostrando homologia com as GSTs de alguns invertebrados (Arif et al., 2004).

Figura 1- Modelo de regulação do sequestro de hexamerinas pelas células do corpo gorduroso de Corcyra cephalonica. Fonte: modificado de Arif et al. (2008).

\subsection{Glutationa S-transferases (GSTs)}

As GSTs são enzimas encontradas em plantas (Edwards et al., 2000), microorganismos (Sheehan \& Casey, 1993; Vuilleumier, 1997), vertebrados (Ketterer et al., 1989; Hayes et al., 2005) e invertebrados (Clark, 1989; Yu, 1996). São divididas em classes segundo suas sequências de aminoácidos, propriedades imunológicas, cinéticas e estruturais (Mannervik et al., 1992; Chelvanayagam et al., 2001).

Os insetos em geral apresentam sete classes de GSTs, sendo 6 classes citosólicas (delta, epsilon, omega, sigma, theta, zeta), e uma classe microssomal, cada classe com número variável de membros. Em Drosophila melanogaster foi identificado um total de 43 membros e em Anopheles gambiae, 37 membros (Ding et al., 2003), quantidade representativamente maior que os 10 membros encontrados em A. mellifera. Já nas plantas são encontradas duas classes: tau e phi (Corona \& Robinson, 2006). Nos mamíferos há três famílias de GSTs e uma variedade de onze classes (Hayes et al., 2005).

As classes delta e epsilon de GSTs são únicas de insetos, e membros desta classe são encontrados em grande número em $A$. gambiae e $D$. melanogaster, como resultado de duplicações gênicas (Sawicki et al., 2003; Ding et al., 2003). Já em A. mellifera não há nenhum representante da classe epsilon e apenas um da classe delta (GSTD1) (Claudianos et al., 2006; Corona \& Robinson, 2006). Segundo Ranson et al. (2002) estas classes de GSTs 
auxiliariam os insetos nas adaptações às pressões seletivas do meio, sendo importantes na resistência do organismo à inseticidas, como por exemplo dicloro-difenil-tricloroetano (DDT), pois atuariam no processo de detoxificação. Desta forma, a maior sensibilidade de $A$. mellifera a alguns inseticidas, quando comparada com outros insetos, seria explicada pela quantidade relativamente reduzida de GSTs que possuem (Claudianos et al., 2006).

No entanto, em A. mellifera o número de representantes da classe sigma é maior que a encontrada nos Diptera, sendo respectivamente, quatro e um. Os genes sigma GSTS1 e GSTS2 de A. mellifera são o único caso de recente duplicação gênica (Claudianos et al., 2006; Corona \& Robinson, 2006). Todos os genes sigma de A. mellifera, GSTS1, GSTS2, GSTS3 e GSTS4 mostram posição homóloga de íntrons, ou seja, evolutivamente conservada, assim como os representantes desta classe de genes em A. gambiae e D. melanogaster (Claudianos et al., 2006). Apenas o gene GSTS2 de A. mellifera apresenta o último íntron em posição diferente em relação aos demais, o que mostra que já houve um acúmulo marcante de diferenças estruturais após o evento de duplicação.

O único gene da classe sigma em Diptera é expresso nos músculos (Franciosa \& Berge, 1995) e, segundo Singh et al. (2001) é importante na detoxificação de lipídeos peroxidados (4-hidroxinonenal). Assim, esta classe de GST estaria mais envolvida na proteção do organismo frente aos produtos do estresse oxidativo originados do metabolismo aeróbico.

Os genes representantes das classes omega e zeta em $D$. melanogaster apresentam duas e uma duplicação, respectivamente. Já a classe theta apresenta duplicações tanto em $D$. melanogaster quanto em A. gambiae. Contudo, em A. mellifera não foram detectadas duplicações nos únicos genes das classes omega (GSTO1), zeta (GSTZ1) e theta (GSTT1) (Claudianos et al., 2006; Corona \& Robinson, 2006).

As GSTs microssomais têm a mesma função que as GSTs citosólicas, ou seja, atuam na detoxificação do organismo e na proteção frente ao estresse oxidativo. Contudo, estas enzimas apresentam estrutura e origem diferentes (Hayes et al., 2005). Em D. melanogaster há uma GST microssomal e em A. gambiae há três membros desta família de enzimas (Toba \& Aigaki, 2000; Ranson et al., 2002). Em A. mellifera os genes codificadores de GSTs microssomais foram denominados GSTmic1 e GSTmic2 (Claudianos et al., 2006)

As enzimas GSTs catalisam a redução de glutationa (GSH) em componentes não polares que contêm átomos de carbono eletrofílico, nitrogênio ou enxofre. Seus substratos incluem halogenonitrobenzenos, óxidos de arenos, quinonas e $\alpha, \beta$-carbonil insaturados. 
Todas as GSTs catalisam a conjugação de GSH com 1-cloro-2,4-dinitrobenzeno (CDNB) e exibem atividade de glutationa peroxidase em relação ao hidroperóxido de isopropilbenzeno, um hidrocarboneto aromático. Algumas ainda catalisam a isomerização de diversos compostos insaturados e, em mamíferos, estão intimamente relacionadas com a síntese de prostaglandinas, leucotrienos, testosterona e progesterona.

Por meio da atuação das GSTs as células se defendem contra xenobióticos, isto é, compostos químicos naturais ou não-naturais estranhos aos organismos (Huber et al., 2008).

Nos mamíferos as GSTs atuam desintoxicando o organismo contra eletrófilos externos, como carcinógenos químicos, poluentes ambientais e agentes antitumorais, além disso, estas enzimas inativam $\alpha, \beta$-aldeídos insaturados, quinonas, epóxidos e hidroperóxidos formados como metabólitos secundários durante o estresse oxidativo, atuando como outras enzimas antioxidantes. A ausência destas enzimas aumenta o risco de algumas doenças, como alteração da função dos pulmões, infarto do miocárdio e acidente vascular cerebral (Hayes et al., 2005).

Em insetos, GSTs são proteínas de grande interesse científico por suas habilidades em degradar vários inseticidas e pesticidas, podendo também promover o transporte intracelular de hormônios, metabólitos e atuar na proteção celular contra o estresse oxidativo (Pickett \& Lu, 1989; Enayati et al., 2005). O estresse oxidativo deve-se à produção de espécies reativas de oxigênio (ROS), ou seja, o ânion superóxido $\mathrm{O}_{2}^{-}$, o peróxido de hidrogênio $\mathrm{H}_{2} \mathrm{O}_{2}$ e radicais hidroxil $\mathrm{HO}$, formados a partir da redução parcial do $\mathrm{O}_{2}$ em consequência do metabolismo aeróbico (Hayes et al., 2005). A formação de ROS ocorre nas mitocôndrias, onde $90 \%$ do oxigênio utilizado pela célula são consumidos (Perez-Campo et al.,1998).

Uma hipótese levantada em alguns estudos mostram que, a ingestão de dietas muito calóricas pode provocar o aumento do estresse oxidativo (Bruce-Keller et al., 2010; Zhang et al., 2005) e, evidências sugerem, que o dano oxidativo causado pelos ROS aos componentes celulares é o maior responsável por doenças degenerativas e envelhecimento (Corona \& Robinson, 2006). O acúmulo de danos oxidativos estaria relacionado ao envelhecimento e a taxa de danos oxidativos acumulados nas células e tecidos determinaria o tempo de vida do organismo (Harman, 1956). A taxa de danos oxidativos depende do balanço entre espécies reativas de oxigênio produzidas e a defesa antioxidante do organismo (Finkel \& Holbrook, 2000). Assim, a maior longevidade seria possibilitada por baixa produção de ROS, aumento da defesa antioxidante ou a combinação dos dois casos (Keller \& Jemielity, 2006). Em A. mellifera, alguns estudos já demonstraram que os níveis de expressão de enzimas 
antioxidantes entre operárias e rainhas não difere, não sendo estas as responsáveis pela maior longevidade das rainhas, mas sim a menor produção de ROS que ocorre nas rainhas em relação às operárias (Corona et al., 2005; Parker et al., 2004).

Além da ação na proteção celular contra o estresse oxidativo, as GSTs aparentemente exercem outras funções nos insetos. No Lepidoptera Spodoptera litura foi proposto que a atividade de uma GST está relacionada à metamorfose, uma vez que o HJ induz a expressão do gene que codifica esta proteína no corpo gorduroso do inseto (Wu \& Lu, 2008).

Em A. mellifera, a atividade de GSTs foi identificada no intestino, cérebro, músculos torácicos, glândulas hipofaríngeas, glândula de veneno e geléia real (Peiren et al., 2008). No entanto, não há na literatura informação sobre o perfil de expressão dos genes codificadores destas proteínas durante a ontogênese desta abelha. Também não se sabe se, de forma similar ao que ocorre no Lepidoptera C. cephalonica, o produto de um destes genes tem função na regulação do sequestro das hexamerinas durante a transição larval-pupal e desenvolvimento do adulto farato. Ainda, não há registro a respeito da atividade dos genes codificadores destas proteínas da família GST frente ao estresse oxidativo provocado pela alimentação, ou no processo de detoxificação de xenobióticos. 


\section{OBJETIVO GERAL}

O presente estudo objetivou a caracterização da estrutura e da expressão, e de aspectos de regulação e função de genes codificadores da família de enzimas glutationa S-transferases em abelhas operárias A. mellifera. O estudo também abrange um aspecto molecular da metamorfose desta abelha referente à dinâmica da estocagem e sequestro de hexamerinas pelo corpo gorduroso, o qual é mediado por uma enzima desta família.

\section{OBJETIVOS ESPECÍFICOS}

Os objetivos específicos deste trabalho de mestrado consistiram em:

I. Validação dos dez genes codificadores de glutationa S-transferases de $A$. mellifera por sequenciamento total ou parcial dos respectivos cDNAs e por estudos de expressão;

II. Verificar a expressão destes genes no corpo gorduroso abdominal e musculatura torácica de operárias adultas em diferentes situações que poderiam caracterizar estresse oxidativo ou resposta a um xenobiótico;

III. Verificar os perfis de expressão de dois dos genes codificadores de glutationa S-transferase, com potencial função na dinâmica de estocagem e sequestro de hexamerinas, no intestino posterior e corpo gorduroso visceral, durante a metamorfose de abelhas operárias. Investigar se estes genes são regulados por variações nos títulos dos hormônios da metamorfose (HJ e 20E) e utilizar silenciamento gênico mediado por RNAi para pesquisa de função. 


\section{MATERIAL E MÉTODOS}

\subsection{Material Biológico}

Abelhas africanizadas A. mellifera foram obtidas de colméias do apiário experimental do Departamento de Genética da Faculdade de Medicina de Ribeirão Preto - USP.

\subsubsection{Coleta de abelhas operárias em estágios larval e pupal}

Operárias em estágios larval e pupal, com idades sincronizadas, foram obtidas pelo confinamento periódico de rainhas para oviposição durante 6 horas em uma área limpa do quadro de cria, por meio de uma tela apropriada. Terminado o confinamento, a rainha era libertada, mas mantinha-se a tela sobre a área dos ovos para impedir novos episódios de oviposição no local. Esta tela impede o acesso da rainha e zangões, mas permite a passagem das operárias que poderão alimentar as larvas quando estas eclodirem.

As diferentes fases do desenvolvimento pré-imaginal de operárias foram identificadas de acordo com os critérios de Michellete \& Soares (1993) (Tabela I).

Tabela I - Parâmetros para identificação das fases do desenvolvimento das operárias utilizadas neste trabalho (segundo Michellete \& Soares, 1993).

\section{Estágios larvais Características}

$\mathbf{L}_{5} \mathbf{S}_{1}$

Intestino totalmente cheio

$\mathbf{L}_{5} \mathbf{S}_{2}$

Intestino em processo de esvaziamento

$\mathbf{L}_{5} \mathbf{S}_{3}$

Intestino totalmente vazio

$\mathbf{P P}_{1}$

Pouco movimento, cabeça orientada em direção ao opérculo, o intestino pode ser visualizado como um tubo vazio

$\mathbf{P P}_{2}$

Imóvel, cabeça orientada em direção ao opérculo, o intestino não é mais visível, os apêndices da cabeça e do tórax são visíveis através da cutícula larval 
$\mathbf{P P}_{3} \quad$ Imóvel, cabeça orientada em direção ao opérculo, o líquido exuvial foi reabsorvido e a cutícula larval tornou-se opaca e enrugada.

Apêndices não podem ser mais visualizados

\begin{tabular}{ccc} 
Fases do estágio pupal & Pigmentação dos olhos & Pigmentação torácica \\
\hline Pw & Branco & Ausente \\
Pp & Rosa & Ausente \\
Pbl & Marrom & Início \\
\hline
\end{tabular}

\subsubsection{Coleta de abelhas operárias forrageiras e nutridoras}

As operárias forrageiras, identificadas pela presença de pólen na corbícula, foram coletadas na entrada das colméias. Já as operárias nutridoras foram obtidas do interior da colônia. A função desempenhada pelas operárias coletadas também foi deduzida do exame das glândulas hipofaríngeas, as quais em operárias forrageiras encontram-se atrofiadas, e em operárias nutridoras estão em pleno funcionamento, apresentando-se mais volumosas. A musculatura torácica e o corpo gorduroso presente no abdômen de 20 abelhas foram coletados para extração de RNA e análise por RT-PCR semiquantitativa.

\subsubsection{Coleta de abelhas operárias para os experimentos de manipulação da} dieta alimentar

Nos experimentos para verificação da influência da dieta alimentar sobre a expressão dos genes de GSTs, operárias recém-emergidas foram coletadas e separadas em 3 grupos de 30 abelhas, que foram confinadas em caixas de madeira medindo $8 \times 11 \times 13 \mathrm{~cm}$. Durante seis dias estas caixas foram mantidas em incubadora com temperatura de $34^{\circ} \mathrm{C}$ e $80 \%$ de umidade relativa. Durante este período cada grupo de abelhas foi alimentado com dietas distintas: 1) xarope (50\% de açúcar em água); 2) beebread (20\% de pólen coletado dos favos em xarope), e 3) geléia real ( $20 \%$ de geléia real em xarope). O alimento foi renovado diariamente e água foi oferecida ad libitum a todos os grupos. No $6^{\circ}$ dia, as operárias foram coletadas para análise por RT-PCR semiquantitativa utilizando amostras de RNA total da musculatura torácica de 12 
abelhas e amostras de corpo gorduroso presente no abdômen de 24 abelhas, divididos em 12 pools de 2 tegumentos abdominal dorsal.

\subsubsection{Coleta de abelhas operárias para os experimentos de tratamento com Pyriproxyfen (PPN)}

Nos experimentos para verificação da influência do tratamento de abelhas adultas com PPN sobre a expressão dos genes GSTs, operárias recém-emergidas foram coletadas e separadas em 3 grupos de 30 abelhas, que foram confinadas em caixas de madeira medindo $8 \times 11 \times 13 \mathrm{~cm}$. Durante seis dias estas caixas foram mantidas em incubadora com temperatura de $34^{\circ} \mathrm{C}$ e $80 \%$ de umidade relativa. Após três dias de confinamento as abelhas do primeiro e do segundo grupos receberam $10 \mu \mathrm{g} / 1 \mu \mathrm{L}$ e $15 \mu \mathrm{g} / 1 \mu \mathrm{L}$ de PPN diluído em acetona, respectivamente. As abelhas do terceiro grupo receberam somente $1 \mu \mathrm{L}$ de acetona (grupo controle). A solução de PPN em acetona, ou somente a acetona, foram aplicados topicamente na região entre a cabeça e o tórax. Os 3 grupos foram alimentados com beebread $(20 \%$ de pólen coletado dos favos em xarope). Água foi oferecida ad libitum a todos os grupos. Em intervalos de tempo correspondentes a 1, 6, 11 e 24 horas após o tratamento, as operárias foram coletadas para análise por RT-PCR semiquantitativa utilizando amostras de RNA total da musculatura torácica de 12 abelhas e do corpo gorduroso abdominal de 24 abelhas (corpo gorduroso de 2 abelhas por amostra).

\subsection{Sequenciamento}

\subsubsection{Caracterização in silico}

A partir da identificação dos genes GSTs por Claudianos et al. (2006) foi realizada uma busca no banco de dados GenBank-NCBI (http://www.ncbi.nlm.nih.gov) pelas sequências de nucleotídeos correspondentes (números de acesso entre parênteses): GSTS1 (GB16959), GSTS2 (GB30268), GSTS3 (GB19254), GSTS4 (GB14372), GSTD1 (GB18045), GSTO1 (GB11466), GSTT1 (GB12047), GSTZ1 (GB17672), GST mic1 (GB12371) e GST mic2/3 (GB10566).

Essas sequências foram anotadas manualmente, in silico, no genoma de A. mellifera (http://www.hgsc.bcm.tmc.edu/projects/honeybee/ - versão 4.0) com auxílio da plataforma 
Artemis 7.0 (Rutherford et al., 2000). As sequências anotadas foram utilizadas para o desenho de primers específicos (Tabela II). Os pares de primers foram desenhados de modo a abranger pelo menos um íntron. Assim, a possível contaminação da RT-PCR por DNA genômico poderia ser facilmente identificada pela presença de banda de maior peso na eletroforese em gel de agarose corado com brometo de etídeo.

Tabela II - Sequências de primers para estudo dos genes GSTs.

\begin{tabular}{|c|c|c|}
\hline Nome & Forward $\left(5^{\prime}-3^{\prime}\right)$ & Reverse $\left(5^{\prime}-3^{\prime}\right)$ \\
\hline hp191 - GSTS1 - 1 & GAAAATGTCCACGTATAAATTGAT & CCTAGTGAGTCCTTAAGAAT \\
\hline hp191 - GSTS1 - RT & CAAGTAAAGAAGAACAAAGG & TCCAAGCATGTCGGTCAAAG \\
\hline$h p 19^{1}$ - GSTS1 - RT1 & TTCCTGGTCTTGCCGAACCA & CTCTTAGCGATCAAGCGAGA \\
\hline GSTS2 & GATGATTGGGAAGCTCTAGA & AGCACCACCAACAAAGTAGC \\
\hline GSTS3 & TCCTCAAAGAATGCTGGCCT & CGTCCCTACCGGTTAGATTA \\
\hline hp19 $19^{2}$ GSTS4 - 1 & GTGTAAAATTGAAATTAGTG & AGACCATATGCAATACCGCC \\
\hline$h p 19^{2}$ - GSTS4 - RT & CGTTACCTGGCCAAACAGTT & CGGTATTACCCTTGTCATTA \\
\hline GSTD1 & TGGCAGGGAAGAACATGACT & CCTCGTATTTCGGTATCTCG \\
\hline GSTO1 & TCСТCTAGCTAGAGCTAAGG & AATGGTGTACCTCTTGATGC \\
\hline GSTT1 & CGTAGCTGATCATTGGTATC & CACTGTTGTTTCTTGTCCAC \\
\hline GSTZ1 & TCTACTCCTATTGGCGGAGT & AGGTACCTGCTCCATTGGAT \\
\hline GSTmic1 & GCAATGGTTCCATTAACTGC & ATGTGCTCTGCGTACACGTT \\
\hline GSTmic2/3 & AACGCCTTGACTTGGTTCAC & GTGTTCAACCATATCGGTGC \\
\hline
\end{tabular}

Para a busca do gene hp19 no genoma de A. mellifera (http://www.hgsc.bcm.tmc.edu/projects/honeybee/ - versão 4.0) foi utilizada a sequência da proteína HP19 obtida por Arif et al. (2004) em C. cephalonica em análise por BLAST. As sequências preditas de GSTS1 e GSTS4 foram identificadas como possíveis genes $h p 19$ de A. mellifera e anotadas com o auxílio da plataforma Artemis 7.0 (Rutherford et al., 2000). As sequências anotadas foram utilizadas para o desenho de primers específicos (Tabela II). 


\subsubsection{Purificação dos cDNAs amplificados por PCR}

Foram obtidos fragmentos de cDNA por transcrição reversa, cujo procedimento está sendo especificado mais adiante no item 3.3.1. Tais fragmentos de cDNA correspondentes aos genes GSTs foram obtidos pela combinação dos primers Forward e Reverse e, para os genes GSTS1 e GSTS4, uma combinação de primers foi utilizada para o sequenciamento total. Todos foram amplificados por PCR e purificados utilizando-se o Kit PureLink Quick Gel Extraction System (Invitrogen ${ }^{\mathrm{TM}}$, Life Technologies).

\subsubsection{Preparo de células competentes - Escherichia coli linhagem DH5a}

Escherichia coli da linhagem DH5 $\alpha$ mantidas a $-70^{\circ} \mathrm{C}$ foram inoculadas em $5 \mathrm{~mL}$ de meio de cultivo LB (Luria Bertani) a $37^{\circ} \mathrm{C}$ sob agitação $(180 \mathrm{rpm})$ por 16 horas. Desse cultivo líquido, $200 \mu \mathrm{L}$ foram utilizados para inocular $500 \mathrm{~mL}$ de meio $\mathrm{LB}$ a $37^{\circ} \mathrm{C}$ sob agitação $(230$ rpm) por 16 horas até atingir densidade óptica de 0,5-0,6, verificada em comprimento de onda de $595 \mathrm{~nm}$ (Ultrospec 2100 pro - Pharmacia). As células, então, foram mantidas em gelo por $30 \mathrm{~min}$ e centrifugadas a $6000 \mathrm{xg}$ por $5 \mathrm{~min}$ a $4^{\circ} \mathrm{C}$. O precipitado foi ressuspendido em $5 \mathrm{~mL}$ de cloreto de cálcio $0,1 \mathrm{M}$ e centrifugado a $6000 \mathrm{xg}$ por $5 \mathrm{~min}$ a $4^{\circ} \mathrm{C}$. O precipitado foi novamente ressuspendido em $5 \mathrm{~mL}$ de cloreto de cálcio $0,1 \mathrm{M}$ acrescido de glicerol (15\%). Em seguida, centrifugou-se a $5000 \mathrm{xg}$ por $15 \mathrm{~min} \mathrm{a} 4^{\circ} \mathrm{C}$ e ao pellet foi adicionado glicerol. Alíquotas de $250 \mu \mathrm{L}$ foram armazenadas à $-70^{\circ} \mathrm{C}$.

\subsubsection{Clonagem}

Os fragmentos de cDNA de GSTS1 e GSTS4 amplificados e analisados em gel de agarose foram utilizados para clonagem. A ligação ao plasmídeo foi realizada através do kit pGEM-T Easy (Promega) a partir de $3 \mu \mathrm{L}$ do cDNA purificado, $1 \mu \mathrm{L}$ do plasmídeo, $1 \mu \mathrm{L}$ de T4 DNA ligase e $5 \mu \mathrm{L}$ de tampão de ligação para T4 DNA ligase. Após incubação a $4^{\circ} \mathrm{C}$ por 16 horas para otimizar a reação e, desta forma, aumentar o número de colônias transformantes, $3 \mu \mathrm{L}$ da mistura de ligação foram utilizados para transformar $250 \mu \mathrm{L}$ de células competentes (E. coli, linhagem DH5a) através de choque térmico $\left(42^{\circ} \mathrm{C}\right.$ por $\left.1 \mathrm{~min}\right)$. As bactérias transformadas foram plaqueadas em meio sólido LB com ampicilina (200 $\mathrm{mg} / \mathrm{mL}$ ), em presença de X-Gal (5-bromo-4-cloro-3-indolil- $\beta$-D-galactopiranosídeo - 50 
$\mathrm{mg} / \mathrm{mL}$ ) e IPTG (isopropil- $\beta$-D-tiogalactopiranosídeo - $200 \mathrm{mg} / \mathrm{mL}$ ). Após 16 horas de incubação a $37^{\circ} \mathrm{C}$, os clones positivos (colônias brancas) foram inoculados em meio LB líquido com ampicilina $(200 \mathrm{mg} / \mathrm{mL})$ por mais 16 horas a $37^{\circ} \mathrm{C}$, sob agitação de $180 \mathrm{rpm}$. Após a clonagem, os plasmídios com inserto foram isolados utilizando-se colunas do Kit de miniprep FastPlasmid Mini (Eppendorf), de acordo com os respectivos protocolos do fabricante. A confirmação da presença dos insertos foi realizada através da digestão dos plasmídeos com enzima de restrição EcoRI (Invitrogen) por 2 horas a $37^{\circ} \mathrm{C}$, visto que o sítio de restrição para esta endonuclease flanqueia o sítio de policlonagem do vetor, destacando o fragmento contendo o inserto. Os resultados foram analisados por eletroforese em gel de agarose 1\% em tampão TBE $1 \mathrm{X}$, corado com brometo de etídeo.

\subsubsection{Sequenciamento e análise das sequências}

Clones positivos, contendo o inserto e os cDNAs purificados dos outros genes GSTs, foram sequenciados pelo método de Sanger, em sistema de sequenciamento automático $A B I$ Prism 310 (Applied Biosystems) utilizando reação com big dye (Perkin Elmer). Para cada reação de amplificação, foram usados $2 \mu \mathrm{L}$ de BigDye (Perkin Elmer), $2 \mu \mathrm{L}$ de tampão de sequenciamento, $2 \mu \mathrm{L}$ de mini-preparação plasmidial, $3 \mu \mathrm{L}$ de água estéril e $1 \mu \mathrm{L}$ de primer sense (F-Forward) ou $1 \mu \mathrm{L}$ de primer antisense (R-Reverse) (Tabela II) para um volume final de $10 \mu \mathrm{L}$. As amplificações ocorreram em 25 ciclos de $96^{\circ} \mathrm{C}-10 \mathrm{~s}, 50^{\circ} \mathrm{C}-5 \mathrm{~s}$ e $60^{\circ} \mathrm{C}-$ 4 min.

As sequências obtidas foram analisadas por meio do programa Sequencher version 4.7 for Windows (Gene Codes Corporation) que avalia as sequências pela qualidade dos eletroferogramas gerados pelo sequenciador, com posterior anotação das mesmas sobre o genoma, com o auxílio da plataforma Artemis 7.0 (Rutherford et al., 2000).

\subsubsection{Análise de similaridade e dedução da sequência de nucleotídeos}

As sequências nucleotídicas consenso completas dos genes GSTS1 e GSTS4, obtidas por sequenciamento e analisadas in silico, foram submetidas ao GenBank (http://www.ncbi.nlm.nih.gov) que atribuiu os seguintes números de acesso: FJ374871 (mRNA) e ACJ12596 (proteína) para GSTS1; FJ873798 (mRNA) e ACP39962 (proteína) para GSTS4. 
As sequências de aminoácidos (deduzidas) das respectivas subunidades protéicas, juntamente com a sequência da proteína HP19 de C. cephalonica (AAQ73932.1) foram utilizadas para alinhamento através do programa ClustalW (http://align.genome.jp/).

\subsection{Estudo da expressão dos genes GSTs}

\subsubsection{Extração do RNA total e síntese do cDNA}

Intestino e corpo gorduroso visceral de operárias em fases pré-imaginais (larvas, pupas e adultas-faratas), e a musculatura torácica e o tegumento abdominal dorsal, que contém o corpo gorduroso em sua face interna, de operárias adultas foram dissecados em Ringer para insetos (5 g NaCl; 0,42 $\left.\mathrm{g} \mathrm{KCl} ; 0,25 \mathrm{~g} \mathrm{CaCl}_{2} .2 \mathrm{H}_{2} \mathrm{O}\right)$ e homogeneizados em $500 \mu \mathrm{L}$ de reagente Trizol (Trizol ${ }^{\circledR}$ Reagent, Invitrogen) para a extração do RNA total, conforme protocolo do fabricante.

Após a extração os RNAs totais foram tratados com 0,1 unidade de DNAse (RQ1 RNAse-free DNAse, Promega) por 30 min a $37^{\circ} \mathrm{C}$, seguida da inativação desta enzima a $70^{\circ} \mathrm{C}$ por 15 min. O RNA obtido foi ressuspenso em água tratada com dietilpirocarbonato (DEPC) $0,1 \%$. As amostras foram quantificadas por espectrofotometria (Nanodrop ${ }^{\circledR}$ ND-1000, NanoDrop Technologies) utilizando-se comprimento de onda de $260 \mathrm{~nm}$. Para avaliação do grau de pureza dos RNAs foi utilizada a razão entre as leituras a 260 e $280 \mathrm{~nm}$, sendo considerada apropriada para a síntese de cDNA as amostras que apresentaram valores entre 1,8 e 2,0 .

Alíquotas de RNA total contendo 1 ou 2,5 $\mu \mathrm{g}$, devidamente quantificadas, foram utilizadas para síntese da primeira fita de cDNA, juntamente com oligo(dT)12-18 Primer (Invitrogen) em reação de transcrição reversa (RT) com a enzima Superscript $I I^{T M}$ (Invitrogen).

\subsubsection{PCR e análise por eletroforese}

Para as amplificações por PCR foram utilizados os cDNAs sintetizados a partir do RNA total e os primers específicos para os genes GSTs (F e R, Tabela II), sendo que para o gene GSTS1 os primers utilizados foram F1 e RT1 e para o gene GSTS4 utilizou-se o par de primers F1 e RT (Tabela II). As condições de PCR foram: 94 por 2 min, seguido por ciclos 
de $94^{\circ} \mathrm{C}, 30 \mathrm{~s}$; temperatura de melting, $1 \mathrm{~min} ; 72^{\circ} \mathrm{C}, 1 \mathrm{~min}$, e extensão final a $72^{\circ} \mathrm{C}$ por $10 \mathrm{~min}$, como mostrado na Tabela III.

Tabela III - Condições de PCR para amplificação das sequências GSTs.

\begin{tabular}{|c|c|c|c|c|}
\hline Gene & Amostra & $\begin{array}{l}\text { Número } \\
\text { de ciclos }\end{array}$ & $\begin{array}{c}\text { Temperatura } \\
\text { de Melting } \\
\left({ }^{\circ} \mathrm{C}\right)\end{array}$ & $\begin{array}{c}\text { Quantidade } \\
\text { de amostra } \\
(\mu \mathrm{L})\end{array}$ \\
\hline \multirow{4}{*}{ GSTS1 } & Musculatura torácica & 35 & \multirow{4}{*}{54} & \multirow{4}{*}{1} \\
\hline & Corpo gorduroso parietal & 30 & & \\
\hline & Intestino & 35 & & \\
\hline & Corpo gorduroso visceral & 35 & & \\
\hline \multirow[b]{2}{*}{ GSTS2 } & Musculatura torácica & 28 & \multirow[b]{2}{*}{58} & \multirow[b]{2}{*}{1} \\
\hline & Corpo gorduroso parietal & 26 & & \\
\hline \multirow{2}{*}{ GSTS3 } & Musculatura torácica & 35 & \multirow{2}{*}{60} & \multirow{2}{*}{1} \\
\hline & Corpo gorduroso parietal & 35 & & \\
\hline \multirow{4}{*}{ GSTS4 } & Musculatura torácica & 32 & \multirow{4}{*}{58} & \multirow{4}{*}{2} \\
\hline & Corpo gorduroso parietal & 25 & & \\
\hline & Intestino & 26 & & \\
\hline & Corpo gorduroso visceral & 26 & & \\
\hline \multirow[t]{2}{*}{ GSTD1 } & Musculatura torácica & 30 & \multirow[t]{2}{*}{60} & \multirow[t]{2}{*}{1} \\
\hline & Corpo gorduroso parietal & 26 & & \\
\hline \multirow[t]{2}{*}{ GSTT1 } & Musculatura torácica & 30 & \multirow[t]{2}{*}{58} & \multirow[t]{2}{*}{1} \\
\hline & Corpo gorduroso parietal & 30 & & \\
\hline
\end{tabular}




$\begin{array}{llll}\text { GSTO1 } & \text { Musculatura torácica } & 31 & 58\end{array}$

Musculatura torácica $\quad 35$

GSTZ1

Corpo gorduroso parietal 28

\begin{abstract}
Corpo gorduroso parietal 28
\end{abstract}
Musculatura torácica $\quad 28$

GSTmic1

Corpo gorduroso parietal

24

Musculatura torácica $\quad 34$

GSTmic2/3

Corpo gorduroso parietal 33

$60 \quad 1$

1

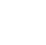

8

4

60

1

As reações foram realizadas com $1 \mu \mathrm{L}$ de primers forward e reverse (RT-F e RT-R, Tabela II) $(10 \mu \mathrm{M}), 1 \mu \mathrm{L}$ cDNA (diluído 10 vezes), $10 \mu \mathrm{L}$ de Eppendorf Master Mix 2,5X (contendo: 10X PCR buffer [200 mM tris- $\mathrm{HCl}(\mathrm{pH} \mathrm{8,4),} 500 \mathrm{mM} \mathrm{KCl}$; $50 \mathrm{mM} \mathrm{MgCl} 2 ; 25$ mM dNTP mix [100 mM de solução de: dTTP; dATP; dGTP e dCTP]; Taq DNA polymerase [5 $\mathrm{U} / \mu \mathrm{L}]$ ), totalizando um volume de $20 \mu \mathrm{L}$ com água bidestilada estéril. O controle da amplificação foi realizado utilizando-se primers específicos para o gene codificador de uma proteína ribossomal de A. mellifera, rp49 (GenBank, número de acesso AB023025). As condições de amplificação foram $94^{\circ} \mathrm{C}$ por 2 min, seguido por 27 ciclos de $94^{\circ} \mathrm{C}, 30 \mathrm{~s} ; 60^{\circ} \mathrm{C}, 1$ $\min ; 72^{\circ} \mathrm{C}, 1 \mathrm{~min} ; 72^{\circ} \mathrm{C}$ de extensão por $10 \mathrm{~min}$.

Aos cDNAs amplificados por PCR foram adicionados $0,8 \mu \mathrm{L}$ de tampão de amostra ( $50 \%$ glicerol; $0,42 \%$ azul de bromofenal; $0,42 \%$ xileno cianol) para análise por eletroforese em gel de agarose $1 \%$ contendo brometo de etídio $(0,3 \mu \mathrm{L} / \mathrm{mL}$ de agarose $)$ em tampão $1 \mathrm{X}$ TBE (0,45 M Tris-base; 0,45 M ácido bórico; 0,5 M EDTA; pH 8,0). A eletroforese foi realizada com uma corrente constante de $100 \mathrm{~V}$. Os resultados foram visualizados e documentados digitalmente com o uso de um foto-documentador KODAK EDAS 290. O 100 bp DNA Ladder (Promega) foi utilizado como marcador do tamanho do fragmento amplificado. 


\subsection{RT-PCR em Tempo Real}

Para comparar quantitativamente os níveis de mRNA do gene GSTS1 nos intestinos de pupas tratadas com 20E, RT-PCR em Tempo Real foi realizada por meio do 7500 Real Time PCR System (Applied Biosystems). A reação de amplificação, com volume final de $20 \mu \mathrm{L}$, continha $10 \mu \mathrm{L}$ de SYBR Green Master Mix $2 X$ (Applied Biosystems), $1 \mu \mathrm{L}$ de cDNA (diluído em água 1:10 v/v), 7,4 $\mu \mathrm{L}$ de água e 1 pmol de cada primer específico (forward: 5' TTCCTGGTCTTGCCGAACCA 3'; reverse: 5' CTCTTAGCGATCAAGCGAGA 3'). O gene rp 49 (número de acesso no GenBank AF441189), que se expressa em níveis similares durante o desenvolvimento das abelhas (Lourenço et al., 2008) foi utilizado como gene normalizador, amplificado com os primers: forward (5`TTGAGCACGTTCAACAATGG 3`) e reverse (5`CGTCATATGTTGCCAACTGGT 3`). A eficiência das reações foi calculada $\left(E=10^{(-1 / \text { slope })}\right)$ para cada gene a partir do slope gerado pela curva de dissociação. As condições de PCR foram $50^{\circ} \mathrm{C}$ por $2 \mathrm{~min}$, e $95^{\circ} \mathrm{C}$ por 10 min seguidos de 40 ciclos de $95^{\circ} \mathrm{C}$ por $15 \mathrm{~s}$, e $60^{\circ} \mathrm{C}$ por $1 \mathrm{~min}$. Para checar a reprodutibilidade, cada reação foi feita em triplicata e repetida com 4 amostras independentes. A quantidade relativa de transcritos do gene GSTS1 foi calculada usando o método $2^{-\Delta \Delta \mathrm{Ct}}$ (Applied Biosystems User bulletin \#2).

\subsection{Tratamento Hormonal}

\subsubsection{Tratamento com 20 -hidroxiecdisona (20E)}

Para testar o efeito de 20E na expressão dos genes GSTS1 e GSTS4, este hormônio foi diluído em 5 partes de etanol absoluto (Merck) e, então, em 100 partes de $\mathrm{NaCl}$ 0,9\% para obter uma concentração final de $5 \mu \mathrm{g}$. Um volume de $1 \mu \mathrm{L}$ desta solução foi injetada na hemocele de pupas, na região abdominal, usando uma microseringa Hamilton (1701LT), agulha G30 (Becton Dickinson). Controles foram injetados somente com o veículo (1 $\mu \mathrm{L}$ de etanol em $\mathrm{NaCl}$ 0,9\% na mesma proporção citada acima). Pupas injetadas foram mantidas em estufa a $34^{\circ} \mathrm{C}$ com $80 \%$ de umidade relativa, até a extração de RNA, ou seja, 5 dias após o tratamento. Larvas de $5^{\circ}$ instar, em fase de alimentação $\left(\mathrm{L}_{5} \mathrm{~F}\right)$ também receberam a solução de 20E, na mesma concentração. Favos contendo larvas neste estágio foram rapidamente removidos da colônia para adição de $20 \mathrm{E}$, com o auxílio de uma micropipeta, ao alimento larval contido nas células larvais. Em seguida, os favos foram devolvidos à colônia. Após 24 
horas de tratamento, as larvas foram coletadas. O RNA total do intestino posterior foi extraído de 20 pupas e 20 larvas tratadas com $20 \mathrm{E}$ e de igual número de controles. Cada amostra de RNA foi preparada com intestinos de 5 pupas ou 5 larvas.

\subsubsection{Tratamento com HJ III e pyriproxyfen (PPN)}

Para testar o efeito de HJ e PPN na expressão dos genes GSTS1 e GSTS4, estas substâncias foram diluídas em acetona $(10 \mu \mathrm{g} / 1 \mu \mathrm{L})$ e aplicadas topicamente sobre larvas $\left(\mathrm{L}_{5} \mathrm{~F}\right.$ - $1 \mu \mathrm{L}$ de hormônio juvenil III - Fluka) e pupas (fase Pp $-1 \mu \mathrm{L}$ de PPN). Controles foram tratados com $1 \mu \mathrm{L}$ de acetona. Após o tratamento, as pupas foram mantidas em estufa, a $34^{\circ} \mathrm{C}$ com $80 \%$ de umidade relativa, e as larvas foram devolvidas à colméia. As larvas foram coletadas 24 horas após o tratamento hormonal, enquanto as pupas foram mantidas em estufa até o $5^{\circ}$ dia após o tratamento, quando foram então coletadas. RT-PCR semiquantitativa foi realizada utilizando amostras de RNA total do intestino posterior de 20 pupas tratadas com PPN, 20 larvas tratadas com HJ e 20 pupas e 20 larvas tratadas com acetona. Cada amostra de RNA foi preparada com intestinos de 5 pupas ou 5 larvas.

\subsection{Silenciamento gênico pós-transcricional de GSTS1}

\subsubsection{Síntese do RNA de fita dupla (dsRNA)}

O RNA de fita dupla foi produzido utilizando-se o kit RiboMAX'TM (Large Scale RNA production System - T7, Promega). Para tanto, foram desenhados primers específicos contendo sítio de ligação a RNA polimerase T7 (em negrito) (forward: 5' TAA TAC GAC TCA CTA TAG GGC GA ATGGAAAGTTGACGTGGGCA 3'; reverse: 5' TAA TAC GAC TCA CTA TAG GGC GA TCCAAGCATGTCGGTCAAAG 3'). Estes primers foram utilizados para amplificação dos DNAs lineares por PCR, ou seja, cDNA de larvas de operárias. As condições de PCR utilizadas foram: $94^{\circ} \mathrm{C}$ por $2 \mathrm{~min} ; 40$ ciclos de $94^{\circ} \mathrm{C}$ por $30 \mathrm{~s}$, $60^{\circ} \mathrm{C}$ por 1 min e $72^{\circ} \mathrm{C}$ por $1 \mathrm{~min}$; e uma extensão final à $72^{\circ} \mathrm{C}$ por $10 \mathrm{~min}$. Após amplificação, uma alíquota do produto de PCR foi submetida à eletroforese em gel de agarose 1\%, para verificação do tamanho dos fragmentos amplificados. O restante foi usado para extração do DNA diretamente do produto da PCR utilizando-se o kit de extração QIAquick ${ }^{\mathrm{TM}}$ (QIAGEN). Os DNAs obtidos foram quantificados e em seguida foram utilizados para as reações de produção do dsRNA. 
A reação de produção do dsRNA foi feita utilizando-se $20 \mu \mathrm{L}$ de tampão de transcrição T7, $30 \mu \mathrm{L}$ de rNTPs ( 25 mM de ATP, CTP, GTP e UTP), $40 \mu \mathrm{L}$ de DNA molde linear (aproximadamente $6 \mu \mathrm{g}$ de DNA) e $10 \mu \mathrm{L}$ do mix de enzimas do kit em uma reação de 8 horas a $37^{\circ} \mathrm{C}$. Os dsRNAs produzidos foram purificados utilizando-se o reagente TRIzol em procedimento recomendado pelo fabricante. O dsRNA foi desnaturado submetendo-os a $98^{\circ} \mathrm{C}$ por $1 \mathrm{~min}$ e resfriado lentamente por $30 \mathrm{~min}$ para renaturação das fitas. Após este procedimento o dsRNA foi submetido à eletroforese para verificar o tamanho do produto e a união das fitas de RNA. O dsRNA foi quantificado e armazenado em freezer $-80^{\circ} \mathrm{C}$ até o momento do uso.

\subsubsection{Tratamento de larvas de operárias com dsRNA}

Para o tratamento com dsRNA, três grupos de larvas de operárias de $4^{\circ}$ instar $\left(\mathrm{L}_{4}\right)$ foram transferidas das colméias para placas de polipropileno com 96 poços (Costar ${ }^{\circledR}$ Corning Incorporated) contendo $40 \mu \mathrm{L}$ de alimento (49\% de geléia real, $6,8 \%$ de frutose, $6,8 \%$ de glicose e $1,1 \%$ de extrato de levedura em água) e mantidas em estufa a $34^{\circ} \mathrm{C}$ com $80 \%$ de umidade relativa. $\mathrm{O}$ alimento foi adicionado aos poços onde já estavam as larvas duas vezes ao dia até elas atingirem o estágio larval $\mathrm{L}_{5} \mathrm{~S}$ ( $5^{\circ}$ instar, fase de tecelagem do casulo).

O desenho experimental para silenciamento do gene GSTS1 incluiu 4 tratamentos: dupla dose de $1 \mu \mathrm{g}$ dsRNA, dupla dose de $5 \mu \mathrm{g}$ dsRNA, tripla dose de $5 \mu \mathrm{g}$ dsRNA, dupla dose de $10 \mu \mathrm{g}$ dsRNA) e um controle (tripla dose do eluente de dsRNA - água nuclease-free). Cada dose de dsRNA ou eluente de dsRNA eram ministradas com 24 horas de intervalo entre elas. Nestes experimentos o dsRNA foi misturado à comida. Larvas foram coletadas 48 horas após o início do tratamento, ou seja, quando atingiam a fase Pbl (adulta-farata intermediária)

para análises por RT-PCR e SDS-PAGE/Western blot. RT-PCR semi-quantitativa foi realizada usando amostras de RNA total do intestino posterior e SDS-PAGE/Western blot foram realizados com amostras de hemolinfa. 


\subsection{Verificação do teor de hexamerinas HEX 70a na hemolinfa}

\subsubsection{Coleta do material}

Hemolinfa de larvas submetidas ao silenciamento do gene GSTS1 foi coletada com o auxílio de micropipetas. As alíquotas de hemolinfa foram estocadas a $-20^{\circ} \mathrm{C}$ e oportunamente processadas para quantificação de proteína total e eletroforese em poliacrilamida e dodecil sulfato de sódio (SDS-PAGE). As amostras foram centrifugadas a $3000 \mathrm{~g}$ por $5 \mathrm{~min}$ a $4^{\circ} \mathrm{C}$. A quantificação de proteínas foi realizada por espectrofotometria (Beckman Coulter - DTX 880 Multimode Detector), de acordo com Bradford (1976), utilizando albumina sérica bovina em curva padrão. Alíquotas contendo $5 \mu \mathrm{g}$ de proteínas foram submetidas a eletroforese e Western blot.

\subsubsection{SDS-PAGE}

As proteínas da hemolinfa foram separadas por eletroforese em gel de poliacrilamida e SDS, contendo $7,5 \%$ da solução de acrilamida/bis acrilamida. O procedimento baseou-se na descrição de Laemmli (1970), com algumas modificações. O gel de separação, medindo $12 \times 10 \times 0,09 \mathrm{~cm}$, foi preparado com $2,5 \mathrm{~mL}$ de solução de acrilamida (30\%)/bisacrilamida(0,8\%); $5 \mathrm{~mL}$ de tampão Tris- $\mathrm{HCl} 0,15 \mathrm{M} \mathrm{pH} 8,8 ; 2,3 \mathrm{~mL}$ de água destilada; $40 \mu \mathrm{L}$ de TEMED; $190 \mu \mathrm{L}$ de persulfato de amônia a 1\%. O gel de empilhamento (4,26\% de acrilamida/bis-acrilamida) foi preparado com $0,375 \mathrm{~mL}$ de acrilamida (30\%)/bisacrilamida $(0,8 \%) ; 1,38 \mathrm{~mL}$ de tampão Tris- $\mathrm{HCl} 0,024 \mathrm{M} \mathrm{pH} \mathrm{6,8;0,825} \mathrm{mL} \mathrm{de} \mathrm{água} \mathrm{destilada;} 10 \mu \mathrm{L}$ de TEMED; $51 \mu \mathrm{L}$ de APS 5\%. O tampão usado nas cubas dos eletrodos era composto por 1,515 $\mathrm{g}$ de Tris-Base, 7,2 g de glicina, 0,5 g de SDS e $250 \mathrm{~mL}$ de água.

\subsubsection{Preparo das amostras}

Diferentes volumes de tampão para amostras (1,51 g de Tris-base; $20 \mathrm{~mL}$ de glicerol; $4 \mathrm{~g} \mathrm{SDS} ; 10 \mathrm{~mL}$ 2-mercaptoetanol; 0,002 g de azul de bromofenol; água destilada até um volume total de $100 \mathrm{~mL}$; $\mathrm{pH}$ 6,75) foram adicionados às alíquotas de hemolinfa para perfazer $1-5 \mu \mathrm{g}$ de proteínas. As amostras foram desnaturadas a $100^{\circ} \mathrm{C}$ por 3 min e aplicadas em gel para migração a $4^{\circ} \mathrm{C}$ e com corrente constante, até que as amostras atingissem o final do gel. 
As proteínas Miosina, $\beta$-Galactosidase, Fosforilase-B, Albumina sérica bovina, Ovoalbumina e Anidrase Carbônica (de 205, 116, 97, 66, 45 e 29 kDa, respectivamente), foram utilizadas como marcadores de massa molecular.

\subsubsection{Western blot}

Imediatamente após a separação por eletroforese, as proteínas foram transferidas para membrana de PVDF (Millipore, Immobilon-P, 0,45 $\mu \mathrm{m} /$ Immuno-Blot $^{\mathrm{TM}} \mathrm{PVDF}$ ) utilizando-se como tampão de transferência a solução: 20 mM Tris, 192 mM Glicina e 20\% etanol absoluto. A transferência ocorreu por 2 horas à temperatura ambiente, sob voltagem constante de $30 \mathrm{~V}$.

Após a transferência as membranas foram coradas com solução de Ponceau para marcação das bandas do marcador, foram lavadas em água destilada por 5 min e incubadas por 16 horas a $4^{\circ} \mathrm{C}$ em uma solução bloqueadora (SB) - $250 \mathrm{~mL}$ de tampão “A” (3,027 g Tris, $0,147 \mathrm{~g} \mathrm{CaCl}_{2}$ e 2,337 $\left.\mathrm{g} \mathrm{NaCl}, \mathrm{pH} 8,5\right), 50 \mathrm{~g}$ de leite em pó desnatado e $500 \mu \mathrm{L}$ de azida sódica 10\%, em um volume final de $500 \mathrm{~mL}$. Após este período, o anticorpo primário (específico) foi diluído em concentração adequada em $20 \mathrm{~mL}$ de SB e em seguida as membranas foram imersas nesta solução e incubadas sob leve agitação por 1 hora à temperatura ambiente. Para os experimentos foi utilizado o anticorpo primário: anti-HEX 70a (Martins et al., 2008), diluição 1:5000.

Posteriormente, as membranas foram lavadas da seguinte forma: 2 lavagens rápidas de 5 min cada e 1 lavagem de 15 min à temperatura ambiente, sob leve agitação, em PBS-Tween - $500 \mu \mathrm{L}$ de Tween em 1 litro de PBS 0,2 M, pH 7,2. Após as lavagens, as membranas foram incubadas por 1 hora em diluição adequada do anticorpo secundário (1:12000) em PBSTween. O anticorpo secundário utilizado foi: anti-rabbit IgG, Horseradish Peroxidase-linked whole antibody, fornecido pelo fabricante do kit (ECL Western Blotting Detection Reagents and Analysis System - Amersham Biosciences). Posteriormente, as membranas foram lavadas novamente em PBS-Tween como descrito acima. Para a detecção do sinal quimioluminescente, as membranas foram incubadas por 1 min utilizando-se $3 \mathrm{~mL}$ de cada reagente de detecção (reagente 1 e 2) do kit.

A reação de detecção foi processada por 1 min no escuro, e em seguida, as membranas foram envolvidas em nova folha plástica e colocadas em cassetes para expor a filmes autoradiográficos (Kodak ${ }^{\circledR}$ XR-Omat/ Hyperfilm ${ }^{\mathrm{TM}} \mathrm{MP}$, Amersham Biosciences) por período 
adequado. A revelação do filme foi feita usando as soluções de revelação e fixação GBX da Kodak $^{\circledR}$.

\subsection{Análise estatística}

Os dados dos grupos experimentais e controles obtidos (1) da quantificação relativa de transcritos do gene GSTS1 por meio de RT-PCR em tempo real, (2) das unidades de densitometria das bandas de SDS-PAGE e Western blots e (3) dos pesos das larvas após o tratamento com dsRNA foram comparados por teste-t. As comparações dos níveis de transcritos dos genes GSTs após o tratamento com alimentação diferencial foi realizada por meio de one-way ANOVA. As comparações entre os grupos tratados com PPN e os respectivos controles foram realizadas utilizando-se one-way ou two-way ANOVA (Jandel SigmaStat 3.5 software, Jandel Corporation, USA). 
RESULTADOS 


\section{RESULTADOS}

\subsection{Sequenciamento e análise dos genes codificadores de GSTs}

Fazendo uso dos pares de primers desenhados para os genes GSTs (ver Tabela II), realizou-se o sequenciamento direto dos fragmentos de cDNA obtidos. Com isto também validou-se a especificidade dos primers utilizados neste trabalho. Para os genes GSTS1 e GSTS4 foram utilizados 3 e 2 pares de primers, respectivamente, o que possibilitou o sequenciamento das regiões codificadoras completas (ou CDSs, coding sequences), entre os códons de início $(\mathrm{ATG}=$ metionina) e de término $(\mathrm{TAA})$ da tradução. Além disto, foram sequenciadas partes das regiões 3' e 5' não-traduzidas (UTRs) destes genes. Estas sequências completas foram depositadas no GenBank [números de acesso de GSTS1: FJ374871 (mRNA) e ACJ12596 (proteína); números de acesso de GSTS4: FJ873798 (mRNA) e ACP39962 (proteína)].

O alinhamento de cada uma das sequências preditas ou determinadas por sequenciamento dos fragmentos de cDNA de GSTs com a respectiva sequência genômica, com o auxílio da plataforma Artemis 7.0 (Rutherford et al., 2000), permitiu determinar a estrutura de cada gene e revelou que os genes GSTS2, GSTS3, GSTmic1, GSTmic2 e GSTmic3 consistem de 2 éxons, porém a proteína predita do gene GSTS2 não se inicia com o aminoácido metionina, o que indica a existência de outro(s) éxon(s); os genes GSTS1, GSTS4 e GSTT1 consistem de 4 éxons e os genes GSTD1, GSTO1 e GSTZ1 consistem de 5 éxons (Fig. 2). A sequência de nucleotídeos do gene GSTmic2 está presente no cromossomo 1, região 71 , contudo neste mesmo cromossomo, região 72 , há uma sequência de nucleotídeos com alta similaridade a qual foi nomeada GSTmic3. Tal similaridade impediu o desenho de primers específicos. Os genes GSTmic2 e GSTmic3 foram então reunidos sob a denominação GSTmic2/3, pois são passíveis de ser amplificados com o mesmo par de primers. GSTS4 cromossomo 4, região 9; GSTD1 - cromossomo 15, região 35; GSTO1 - cromossomo 1, região 35; GSTZ1 - cromossomo 5, região 16; GSTmic1 - cromossomo 2, região 38; GSTS1, GSTS2, GSTS3 e GSTT1 - cromossomo não determinado. 


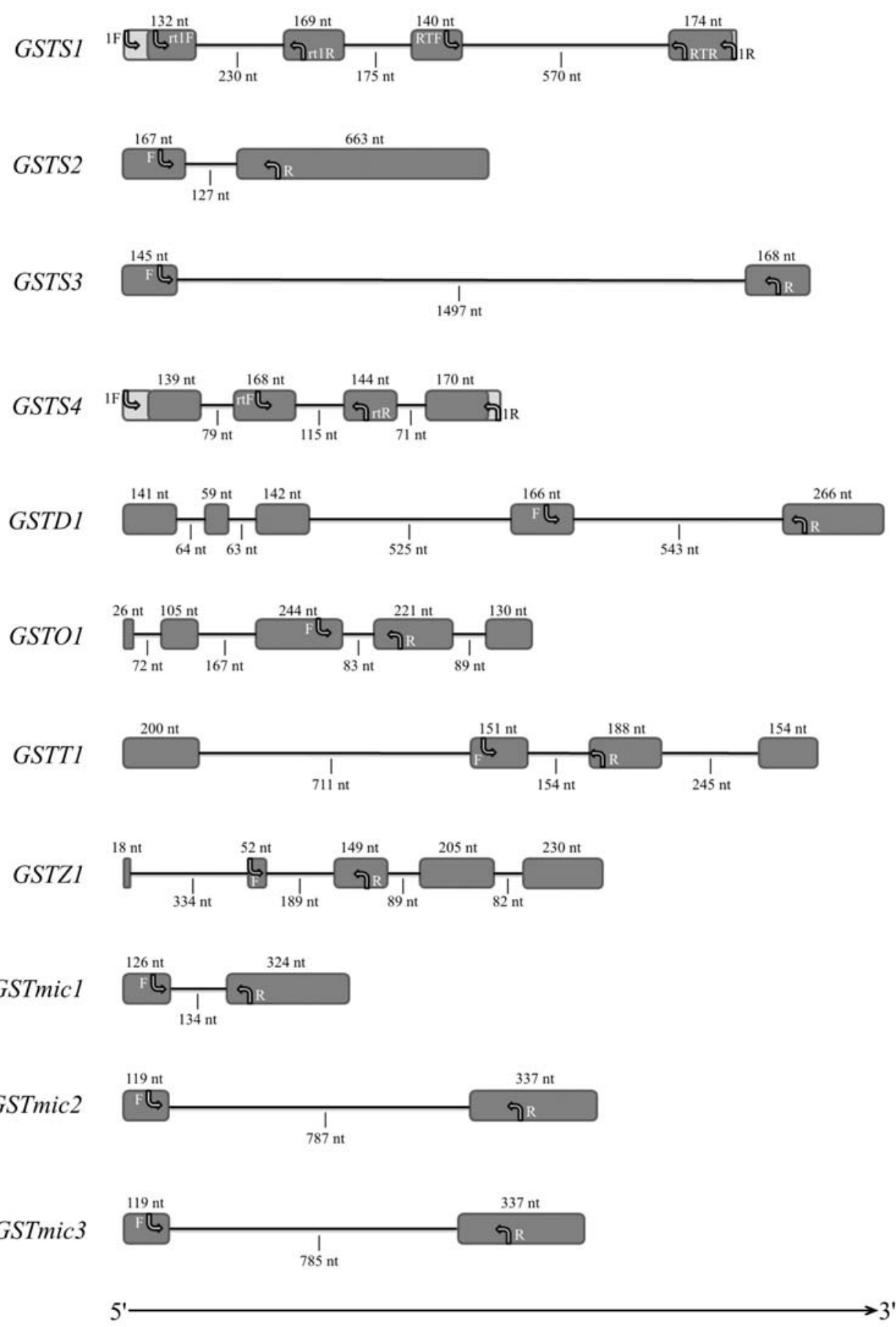

Figura 2 - Diagrama da estrutura dos genes GSTs de A. mellifera. Os éxons e introns são representados por caixas e linhas, respectivamente. Regiões UTRs estão marcadas com a cor cinza claro (5'-UTR: 71nt para GSTS1 e 65nt para GSTS4; 3'-UTR: 4nt para GSTS1 e 26nt para GSTS4). As posições dos primers específicos utilizados para o sequenciamento e estudo de expressão estão identificadas por setas nas caixas. A seta abaixo da figura mostra a direção da transcrição.

As proteínas preditas dos genes GSTS1 e GSTS4 contêm os domínios conservados GST_N_Sigma_like e GST_C_Sigma_like. As proteínas preditas dos genes GSTS2 e GSTS3 apresentaram somente um destes domínios: GST_C_Sigma_like e GST_N_Sigma_like, respectivamente. A proteína predita do gene GSTD1 apresenta domínios conservados 
GST_N_Delta_Epsilon e GST_C_Delta_Epsilon, não há em A. mellifera proteínas da classe Epsilon, porém este domínio é semelhante ao Delta, motivo este da denominação conjunta; a proteína predita do gene GSTO1 apresenta domínios conservados GST_N_Omega e GST_C_Omega; a proteína predita do gene GSTT1 apresenta domínios conservados GST_N_Theta e GST_C_Theta; a proteína predita do gene GSTZ1 apresenta domínios conservados GST_N_Zeta e GST_C_Zeta; a proteína predita do gene GSTmic1 apresenta

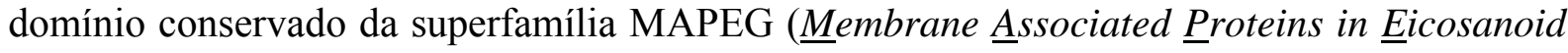
and Glutathione metabolism) (Fig. 3). Os genes GSTmic2/3 não apresentam domínios conservados.

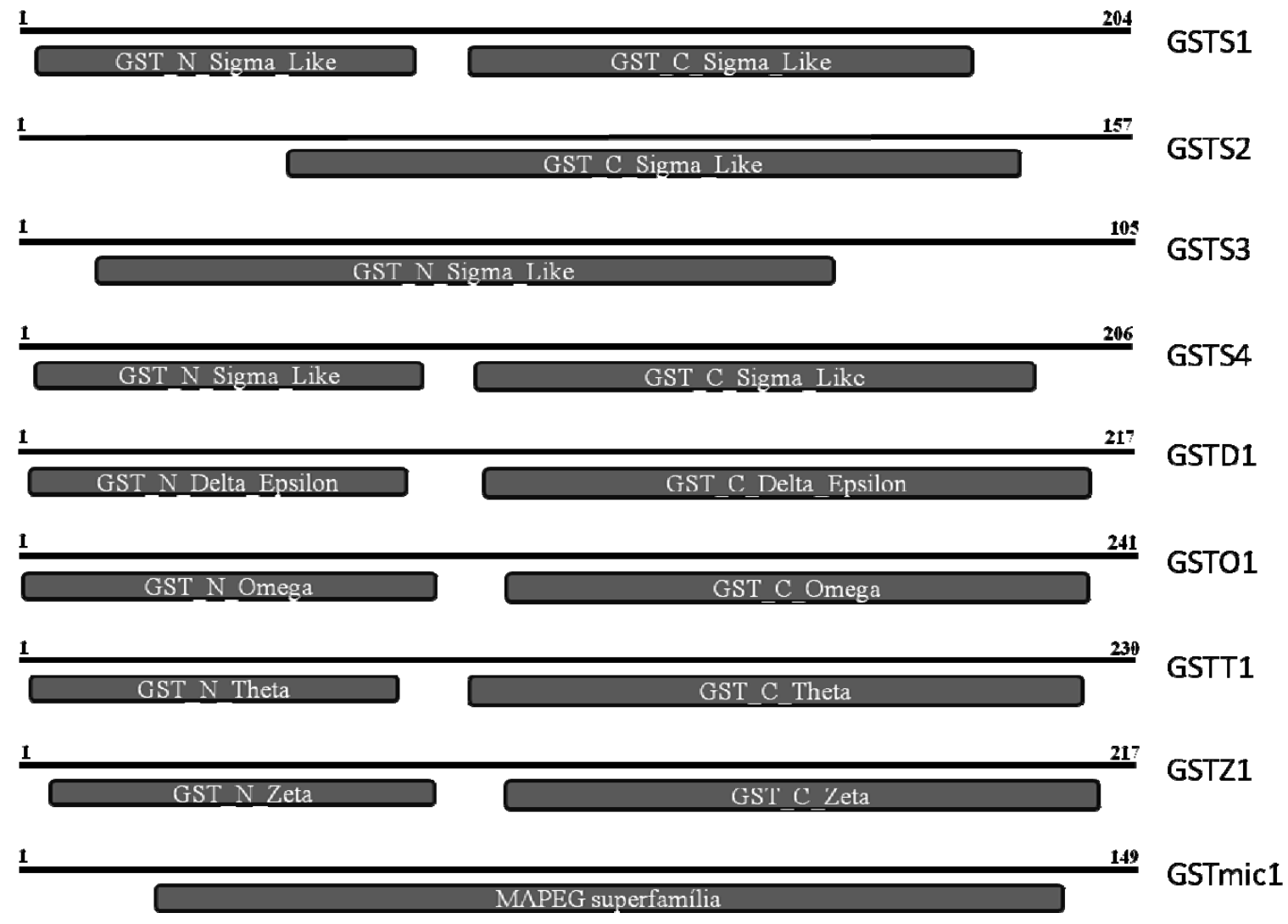

Figura 3 - Diagramas das proteínas GSTs mostrando os domínios conservados.

A massa molecular das proteínas preditas foi determinada através do programa Expasy (http://web.expasy.org/protparam/) e está entre 12,2 e 27,98 kDa, como mostrado no Apêndice 1.

Desta forma, os primers desenhados amplificaram total ou parcialmente as CDSs dos genes GSTs de A. mellifera. As respectivas proteínas preditas apresentam domínios 
conservados típicos das GSTs de insetos (Ding et al., 2003), com exceção das proteínas deduzidas das sequências nucleotídicas GSTmic1 e GSTmic2/3.

\subsection{Expressão dos genes codificadores de GSTs}

A expressão dos genes GSTs foi caracterizada em diferentes condições, conforme especificado nos itens subsequentes.

\subsubsection{Análise da expressão dos genes GSTs em tecidos de operárias forrageiras} e nutridoras

Para analisar a expressão dos genes GSTs em operárias que exerciam diferentes funções na colméia e, portanto, tinham idades distintas, foram realizadas RT-PCRs utilizandose RNA total extraído do corpo gorduroso abdominal (parietal) e da musculatura torácica. Foram observados, em sua maioria, níveis mais elevados de transcritos nos tecidos de operárias forrageiras, mais velhas, do que nos tecidos das nutridoras, mais jovens.

No corpo gorduroso, análises estatísticas mostraram que para oito dos dez genes GSTs a diferença de transcritos entre nutridoras e forrageiras é significante, sendo maior a densidade de transcritos em forrageiras. Apenas os genes GSTS4 e GSTmic2/3 não apresentaram diferença significante quanto aos níveis de transcritos entre estes dois grupos de abelhas (Fig. 4). 

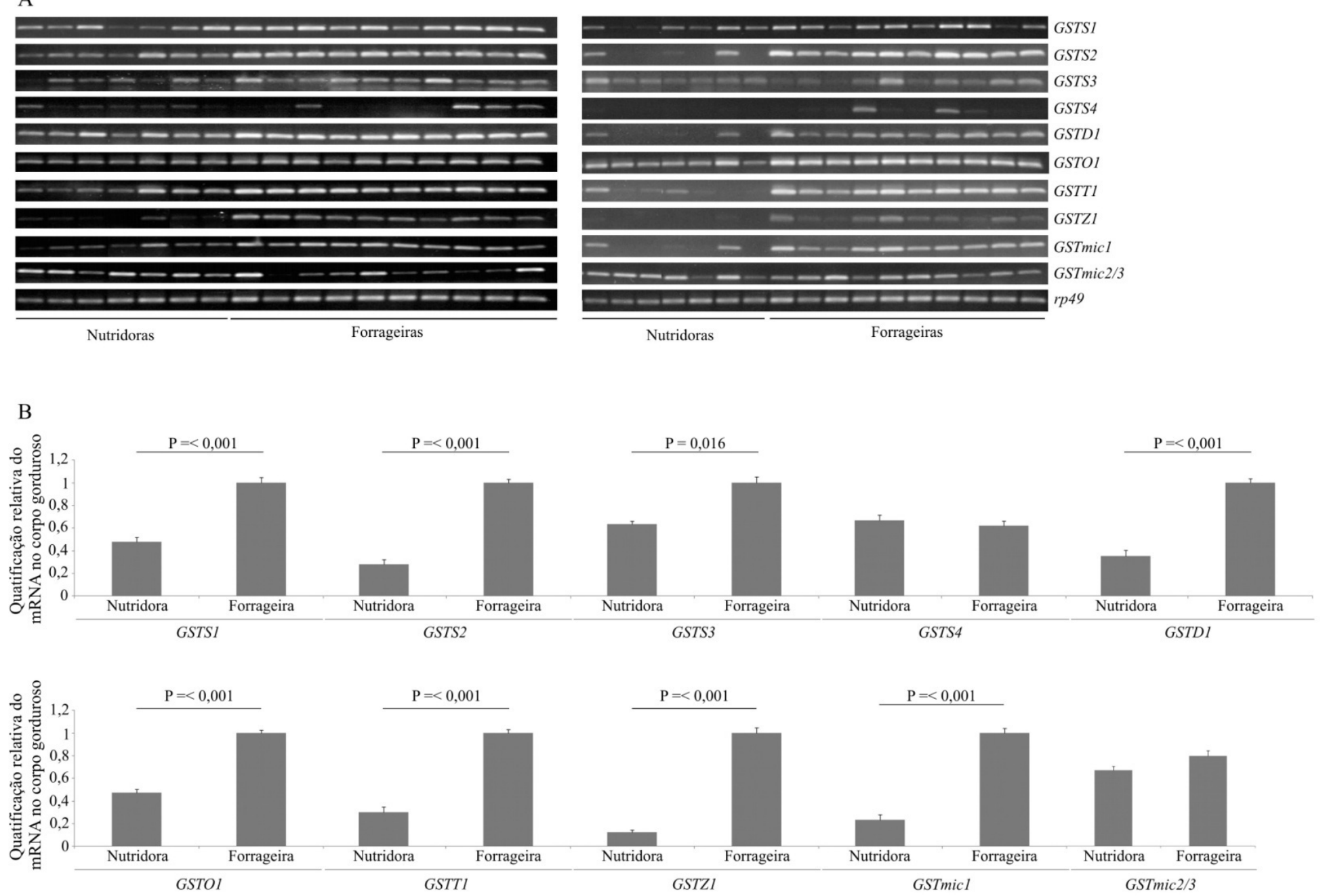

Figura 4 - Padrão de expressão de GSTs no corpo gorduroso parietal de operárias de A. mellifera nutridoras $(\mathrm{n}=14)$ e forrageiras $(\mathrm{n}=20)$. A) RT-PCR semiquantitativa: transcrição reversa e amplificação do cDNA, seguida de eletroforese em gel de agarose corado com brometo de etídeo. O gene com expressão constitutiva, rp49, foi utilizado como normalizadorda RT-PCR. B) Quantificação relativa usando densitometria. Os níveis de transcritos são estatisticamente diferentes entre os grupos quando $\mathrm{P}<0.050$ (teste-t; Jandel SigmaStat 3.1 software, Jandel Corporation, USA). 
$\mathrm{Na}$ musculatura torácica, seis dos dez genes apresentaram diferença estatisticamente significante nos níveis de transcritos na comparação entre os grupos de operárias nutridoras e forrageiras, também com maior densidade de transcritos nas forrageiras. Os genes GSTS1, GSTS3, GSTS4 e GSTmic2/3 foram os que não mostraram diferença significante nos níveis de transcritos entre os grupos estudados (Fig. 5). 
A
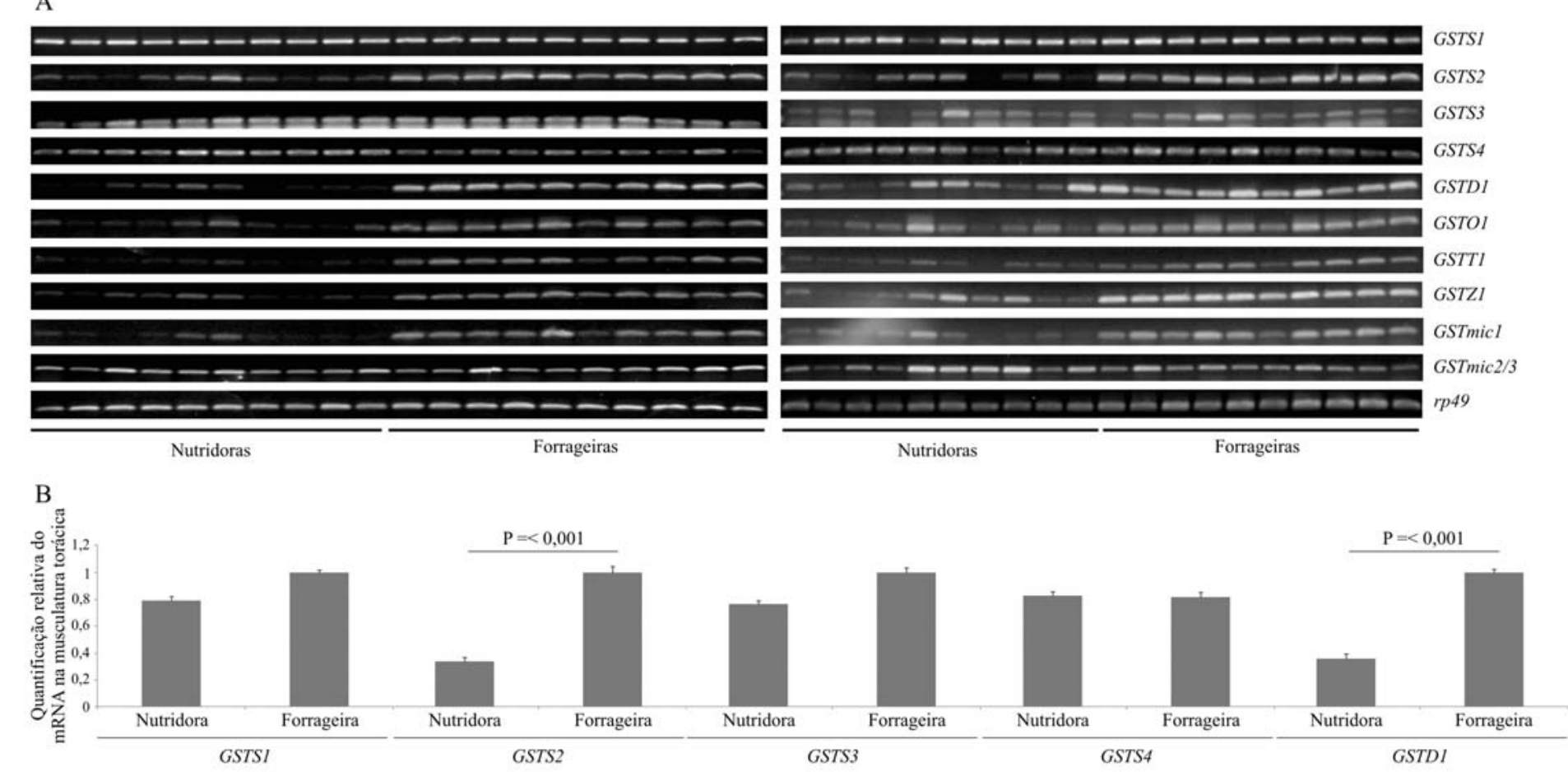

Forrageiras

Nutridoras

Forrageiras

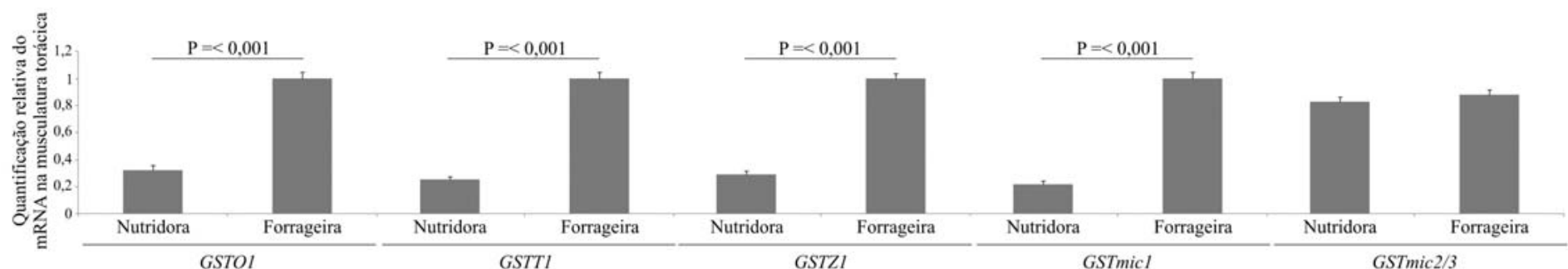

Figura 5 - Padrões de expressão dos genes GSTs na musculatura torácica de operárias de A. mellifera nutridoras $(\mathrm{n}=20)$ e forrageiras $(\mathrm{n}=20)$. A) RT-PCR semiquantitativa: transcrição reversa e amplificação do cDNA, seguida de eletroforese em gel de agarose corado com brometo de etídeo. O gene com expressão constitutiva, rp49, foi utilizado como normalizador da RT-PCR. B) Quantificação relativa usando densitometria. Os níveis de transcritos são estatisticamente diferentes entre os grupos quando P $<0.050$ (teste-t; Jandel SigmaStat 3.1 software, Jandel Corporation, USA). 
No geral, foi possível notar níveis mais elevados de transcritos dos genes GSTs em tecidos de operárias forrageiras em detrimento de operárias nutridoras. Os genes GSTS4 e GSTmic2/3 não mostraram diferença significante de expressão em ambos os tecidos estudados, corpo gorduroso parietal e musculatura torácica, de abelhas nutridoras e forrageiras. A expressão de GSTS1 e GSTS3 não diferiu na comparação das amostras de musculatura torácica de nutridoras e forrageiras.

\subsubsection{Análise de expressão dos genes GSTs em tecidos de abelhas operárias} alimentadas com diferentes dietas

Para alguns dos genes GSTs a quantidade de transcritos tanto no corpo gorduroso abdominal (parietal) quanto na musculatura torácica mostrou-se maior nos grupos de abelhas operárias aos quais foram oferecidos alimentos com maior teor de proteínas, ou seja, geléia real e beebread e isto foi estatisticamente confirmado. Para outros genes GSTs a diferença observada não foi validada pelos testes estatísticos.

Em relação à expressão no corpo gorduroso, os genes GSTS1, GSTS2 e GSTS4 apresentaram expressão significantemente maior nos grupos de operárias alimentadas com geléia real ou beebread em detrimento de xarope. De modo semelhante, o gene GSTD1 mostrou maior densidade de transcritos nos tratamentos com geléia real e beebread que com xarope, porém entre as abelhas alimentadas com as dietas protéicas, aquelas que receberam geléia real apresentaram os mais altos níveis de transcritos GSTD1. Os níveis de transcritos GSTT1 foram significativamente mais altos no grupo de abelhas alimentadas com geléia real que com xarope. A expressão dos genes GSTO1, GSTZ1, GSTmic1 e GSTmic2/3 não diferiu estatisticamente entre os grupos alimentados com as diferentes dietas (Fig. 6), embora níveis mais baixos de transcritos tenham sido consistentemente detectados nas abelhas alimentadas com xarope. 

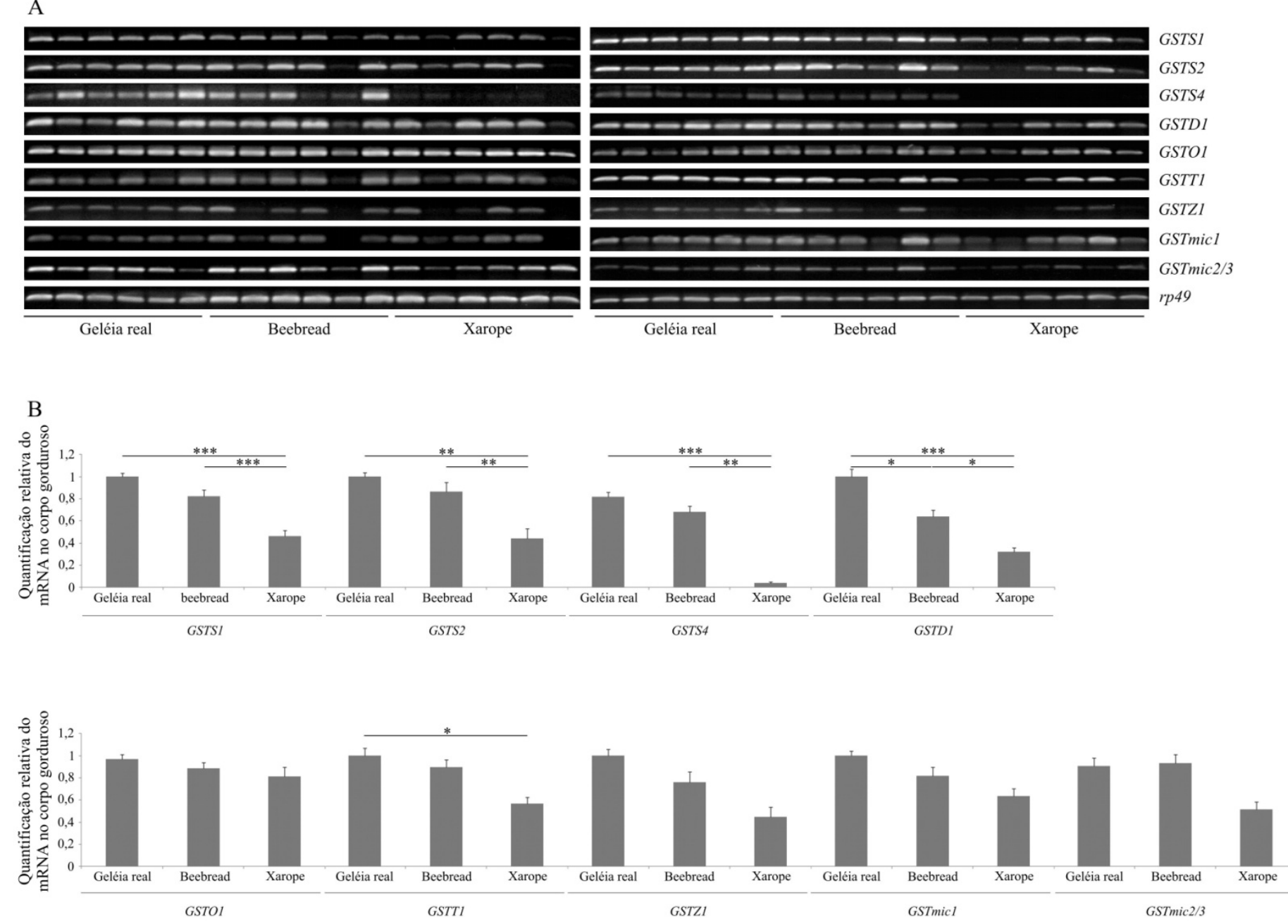

Figura 6 - Padrões de expressão dos genes GSTs no corpo gorduroso parietal de operárias de A. mellifera alimentadas com geléia real $(\mathrm{n}=12)$, beebread (n = 12) ou xarope $(\mathrm{n}=12)$. A) RT-PCR semiquantitativa: transcrição reversa e amplificação do cDNA, seguida de eletroforese em gel de agarose corado com brometo de etídeo. O gene de expressão constitutiva, rp49, foi utilizado como normalizador da RT-PCR. B) Quantificação relativa usando densitometria. Os níveis de transcritos são estatisticamente diferentes entre os grupos quando apresentam asteriscos sobre a coluna ( ${ }^{*} \mathrm{P} \leq 0.050$; ** $\mathrm{P} \leq 0,010$ e ***P $\leq 0,001$, one-way ANOVA - Holm Sidak; Jandel SigmaStat 3.1 software, Jandel Corporation, USA). 
$\mathrm{Na}$ musculatura torácica os níveis de transcritos também foram em geral superiores nos grupos de operárias alimentadas com geléia real e/ou beebread que com xarope e esta diferença foi estatisticamente validada para quatro (GSTS2, GSTS4, GSTT1 e GSTmic2/3) dos dez genes estudados. Embora os níveis de expressão dos genes GSTS1, GSTD1, GSTO1, GSTZ1 e GSTmic1 tenham sido sempre mais baixos na musculatura torácica das abelhas alimentadas com xarope, esta diferença não foi corroborada pelos testes estatísticos (Fig. 7). 
A
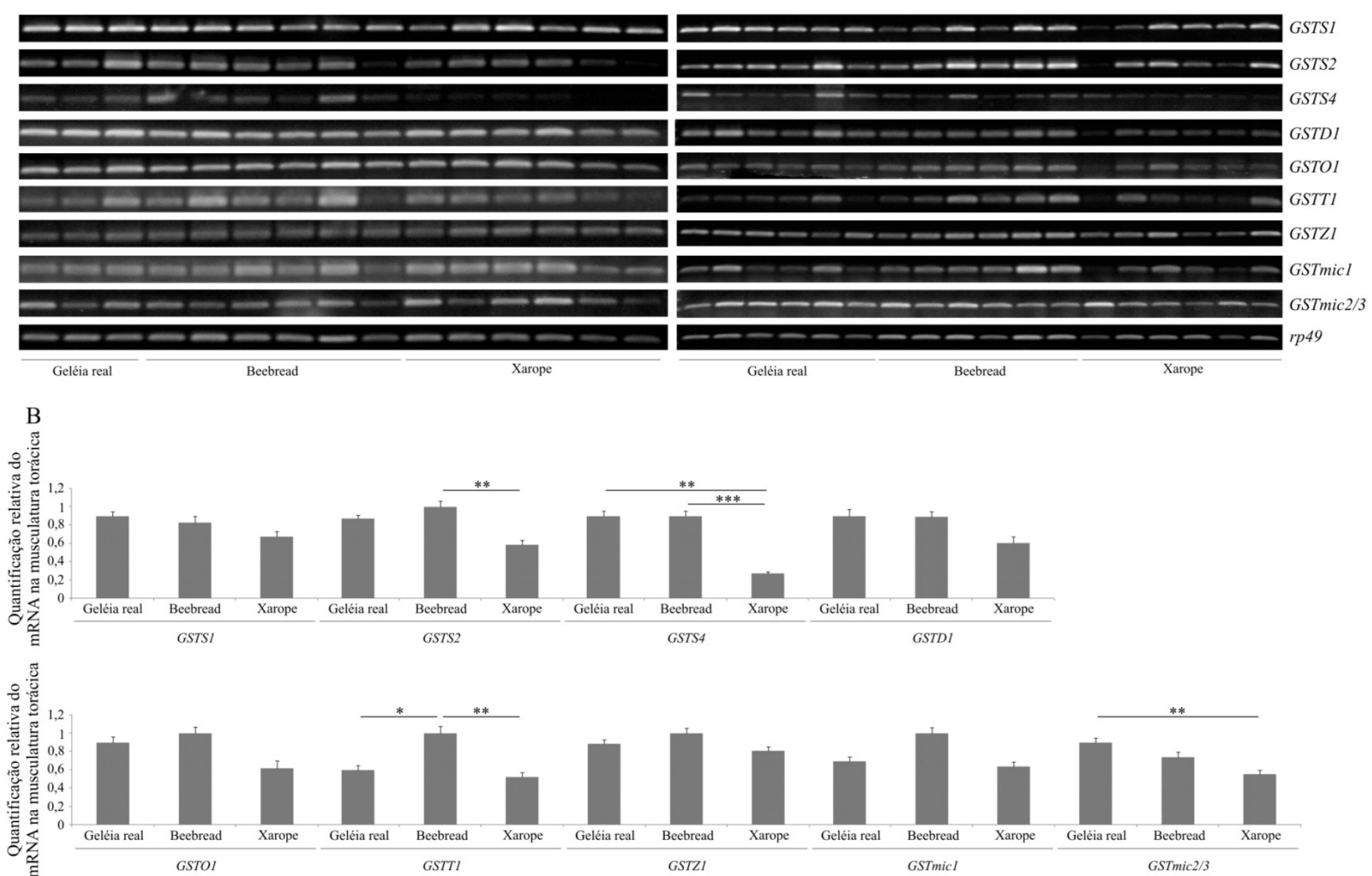

Figura 7 - Padrões de expressão dos genes de GSTs na musculatura torácica de operárias de A. mellifera alimentadas com geléia real $(\mathrm{n}=9)$, beebread $(\mathrm{n}=12)$ ou xarope $(\mathrm{n}$ = 12). A) RT-PCR semiquantitativa: transcrição reversa e amplificação do cDNA, seguida de eletroforese em gel de agarose corado com brometo de etídeo. O gene de expressão constitutiva, rp49, foi utilizado como normalizador da RT-PCR. B) Quantificação relativa usando densitometria. Os níveis de transcritos são estatisticamente diferentes entre os grupos quando apresentam asteriscos sobre a coluna (*P $\leq 0.050$; **P $\leq 0,010$ e ***P $\leq 0,001$, one-way ANOVA - Holm Sidak; Jandel SigmaStat 3.1 software, Jandel Corporation, USA). 
Em resumo, foi possível notar maior densidade de transcritos nos tecidos de abelhas alimentadas com geléia real e beebread que com xarope, porém nem sempre esta diferença foi validada pelas análises estatísticas. Não foi obtido expressão do gene GSTS3 em nenhum dos dois tecidos dos grupos de abelhas alimentadas com as diferentes dietas.

\subsubsection{Análise de expressão dos genes GSTs em tecidos de abelhas operárias} adultas 24 horas após tratamento com PPN

No corpo gorduroso parietal das abelhas tratadas com qualquer das duas doses de PPN (10 ou $15 \mu \mathrm{g}$ de PPN diluídos em acetona) houve significante redução dos níveis de transcritos de GSTS2, GSTD1, GSTO1 e GSTmic1 em relação ao grupo controle que recebeu somente o diluente de PPN. O tratamento com $15 \mu \mathrm{g}$ de PPN reduziu significantemente os níveis de transcritos GSTS1 e GSTZ1 em relação aos respectivos grupos controles. Os genes GSTS4, GSTT1 e GSTmic2/3 mostraram menor expressão sob efeito de PPN, mas esta diferença não foi passível de validação pelos testes estatísticos utilizados (Fig. 8). Observe-se que a série de géis à esquerda da Fig. 8A mostra de modo mais evidente o efeito inibidor de PPN sobre a expressão da maioria dos genes GSTs que a série de géis à direita da Fig. 8A. 
A

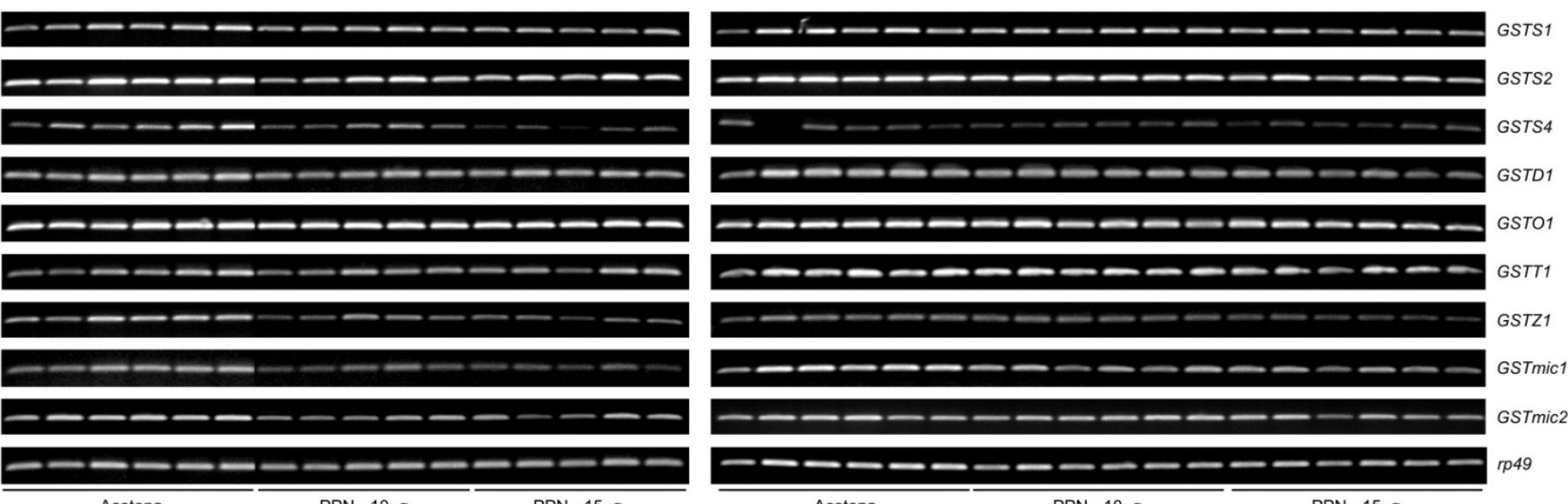

B

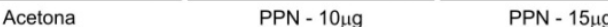

Acetona

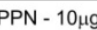

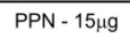
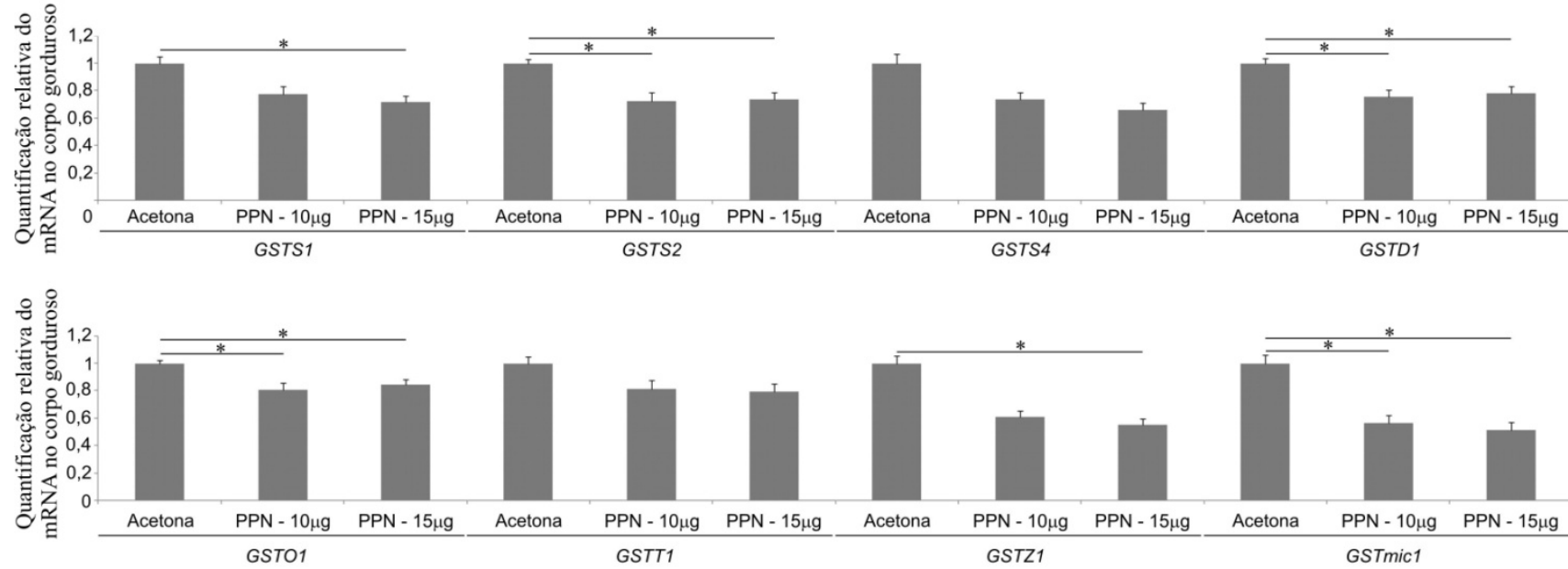

GSTS4

GSTD1

Figura 8 - Padrões de expressão dos genes GSTs no corpo gorduroso parietal de operárias de A. mellifera tratadas com $10(\mathrm{n}=11)$ ou $15 \mu \mathrm{g}(\mathrm{n}=11)$ de PPN diluído em acetona, ou somente com acetona (controles, $\mathrm{n}=12$ ). O tempo decorrido do tratamento até a coleta do corpo gorduroso foi de 24 horas. A) RT-PCR semiquantitativa: transcrição reversa e amplificação do cDNA, seguida de eletroforese em gel de agarose corado com brometo de etídeo. O gene de expressão constitutiva, rp49, foi utilizado como normalizador da RT-PCR. B) Quantificação relativa usando densitometria. Os níveis de transcritos são estatisticamente diferentes entre os grupos quando apresentam asteriscos sobre a coluna $\left({ }^{*} \mathrm{P} \leq 0.050 ; * * \mathrm{P} \leq 0,010\right.$ e $* * * \mathrm{P} \leq 0,001$, one-way ANOVA - Holm Sidak; Jandel SigmaStat 3.1 software, Jandel Corporation, USA). 
Na musculatura torácica os genes GSTS1, GSTS2, GSTD1, GSTO1, GSTT1 e GSTmic1 mostraram expressão significantemente menor nos grupos de abelhas tratadas com PPN em relação aos respectivos grupos controle. Os genes GSTS4, GSTZ1 e GSTmic2/3 não mostraram níveis de transcritos estatisticamente diferentes na comparação entre os grupos tratados e controles, apesar da tendência de redução de transcritos com a dose de $10 \mu \mathrm{g}$ de PPN (Fig. 9). 

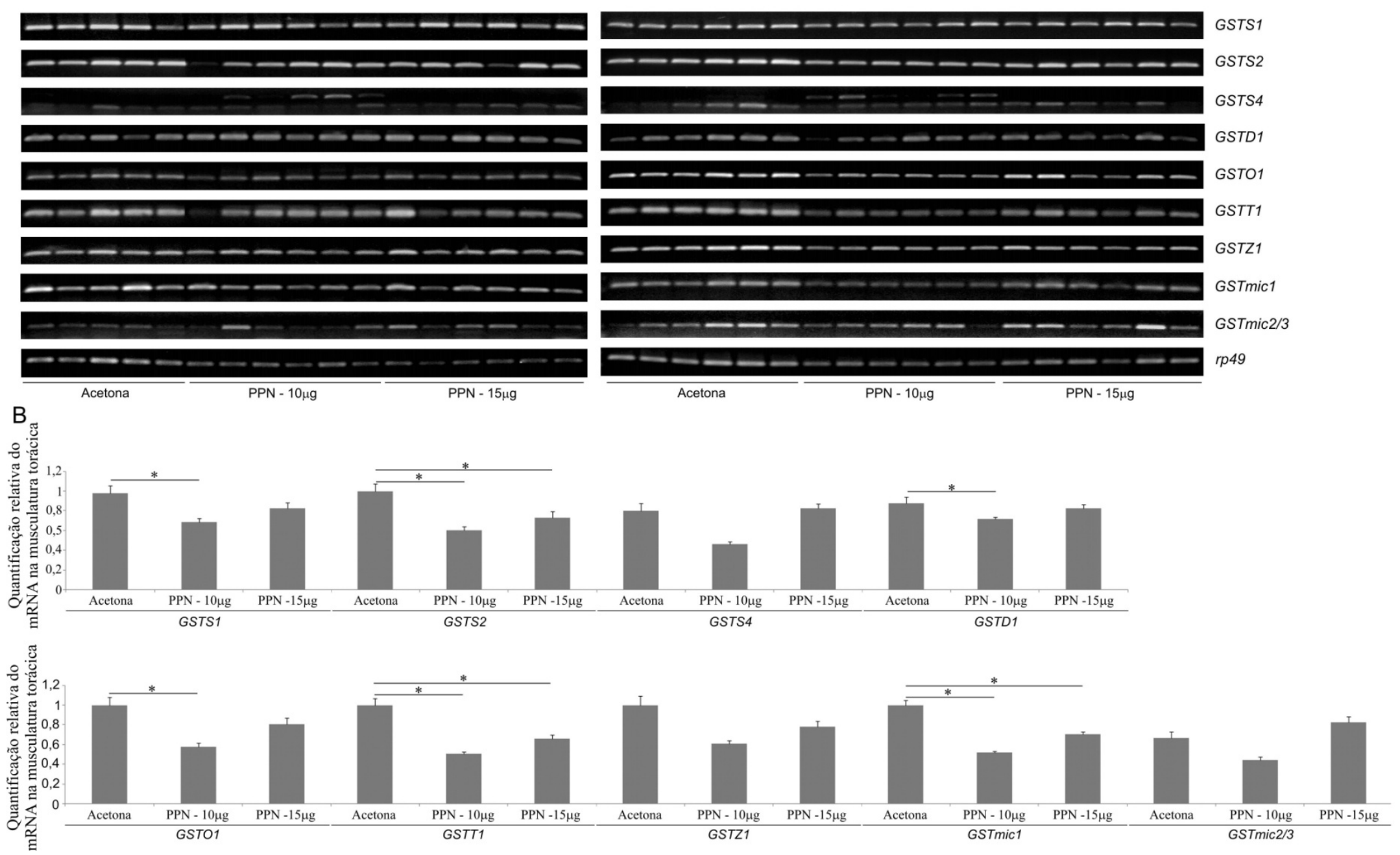

Figura 9 - Padrões de expressão dos genes GSTs na musculatura torácica de operárias de A. mellifera tratadas com $10(\mathrm{n}=12)$ ou $15 \mu \mathrm{g}(\mathrm{n}=12)$ de PPN diluído em acetona, ou somente com acetona (controles, $\mathrm{n}=11$ ). O tempo decorrido do tratamento até a coleta do tecido muscular foi de 24 horas. A) RT-PCR semiquantitativa: transcrição reversa e amplificação do cDNA, seguida de eletroforese em gel de agarose corado com brometo de etídeo. O gene de expressão constitutiva, rp49, foi utilizado como normalizador da RT-PCR. B) Quantificação relativa usando densitometria. Os níveis de transcritos são estatisticamente diferentes entre os grupos quando apresentam asteriscos sobre a coluna $\left({ }^{*} \mathrm{P} \leq 0.050 ;{ }^{* *} \mathrm{P} \leq 0,010\right.$ e ***P$\leq 0,001$, one-way ANOVA - Holm Sidak; Jandel SigmaStat 3.1 software, Jandel Corporation, USA). 
Assim, seis dos nove genes GSTs aqui estudados mostraram redução estatisticamente significante nos níveis de transcritos tanto no corpo gorduroso parietal (genes GSTS1, GSTS2, GSTD1, GSTO1, GSTZ1, GSTmic1) quanto na musculatura torácica (genes GSTS1, GSTS2, GSTD1, GSTO1, GSTT1, GSTmic1) de abelhas operárias tratadas com PPN, em relação aos respectivos grupos controles. O gene GSTS3 não apresentou expressão em nenhum dos dois tecidos, nas condições estabelecidas para este estudo.

\subsubsection{Análise de expressão dos genes GSTS2 e GSTmic1 em tecidos de} abelhas operárias, decorridos 1, 6 e 11 horas após o tratamento com PPN

Dois dos genes GSTs (GSTS2 e GSTmic1) que haviam apresentado significante redução dos níveis de transcritos 24 horas após tratamento tópico com PPN foram utilizados para averiguar o efeito nos tempos de 1, 6 e 11 horas após o tratamento. A dose de PPN utilizada foi de $10 \mu \mathrm{g}$, já que provocou redução significante de transcritos em 24 horas, tanto no corpo gorduroso parietal (ver Fig. 8) quanto na musculatura torácica (ver Fig. 9).

No corpo gorduroso parietal, os níveis de transcritos dos genes GSTS2 e GSTmic1 não diferiram estatisticamente entre as abelhas tratadas com PPN e controles, considerando-se os tempos de 1, 6 e 11 horas após a aplicação tópica de PPN (Fig. 10). 
A

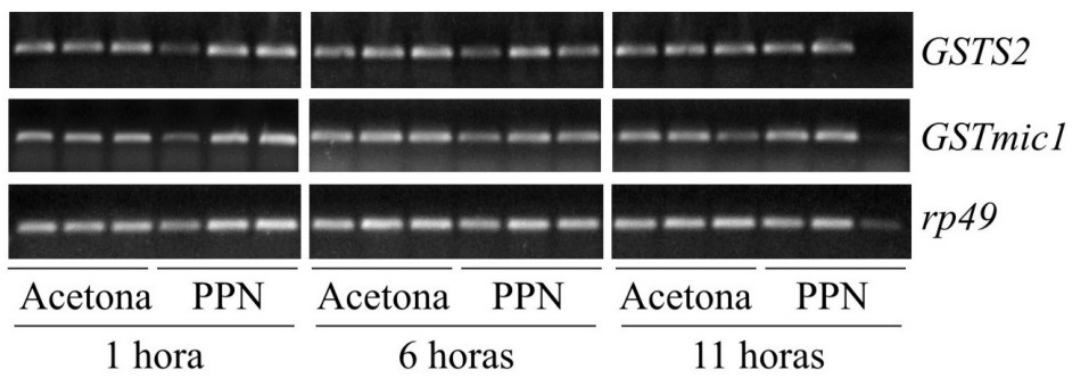

$\mathrm{B}$
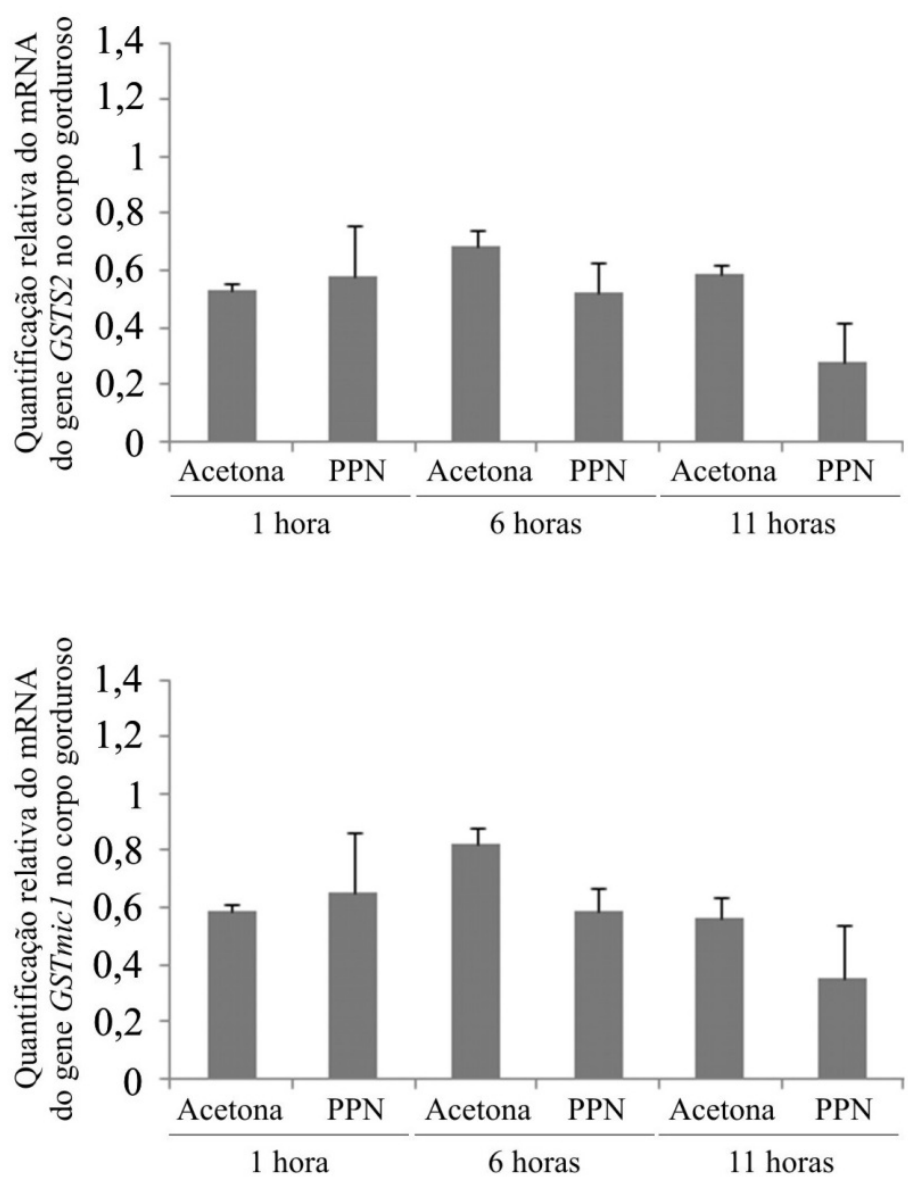

Figura 10 - Padrões de expressão dos genes GSTS2 e GSTmic1 no corpo gorduroso parietal de operárias adultas de A. mellifera tratadas com $10 \mu \mathrm{g}$ de PPN diluído em acetona, ou somente com acetona (controles), decorridos 1,6 e 11 horas entre o tratamento e a coleta do corpo gorduroso. A) RT-PCR semiquantitativa: transcrição reversa e amplificação do cDNA, seguida de eletroforese em gel de agarose corado com brometo de etídeo. O gene de expressão constitutiva, rp49, foi utilizado como normalizador da RT-PCR. B) Quantificação relativa usando densitometria.

$\mathrm{Na}$ musculatura torácica houve tendência de aumento dos níveis de transcritos de ambos os genes, GSTS2 e GSTmic1, nas abelhas tratadas com PPN em relação às controles, decorrida 1 hora do tratamento. Para o gene GSTmic1 esta diferença situou-se no limite de 
significância $(\mathrm{P}=0,048)$. Após 6 e 11 horas, os níveis de transcritos não diferiram entre as abelhas tratadas ou não com PPN (Fig. 11).

A

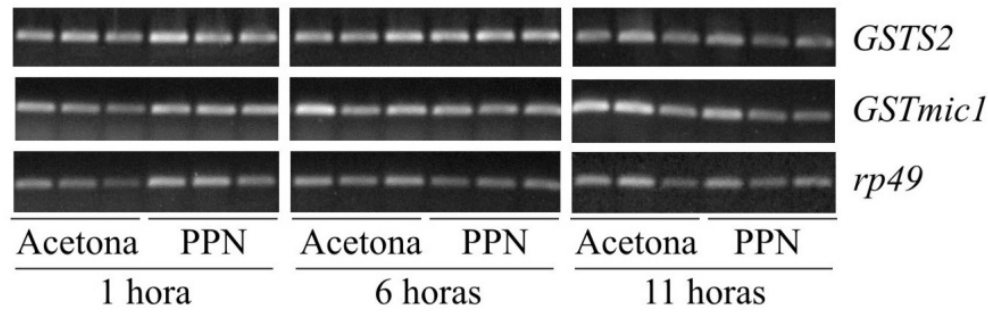

$\mathrm{B}$
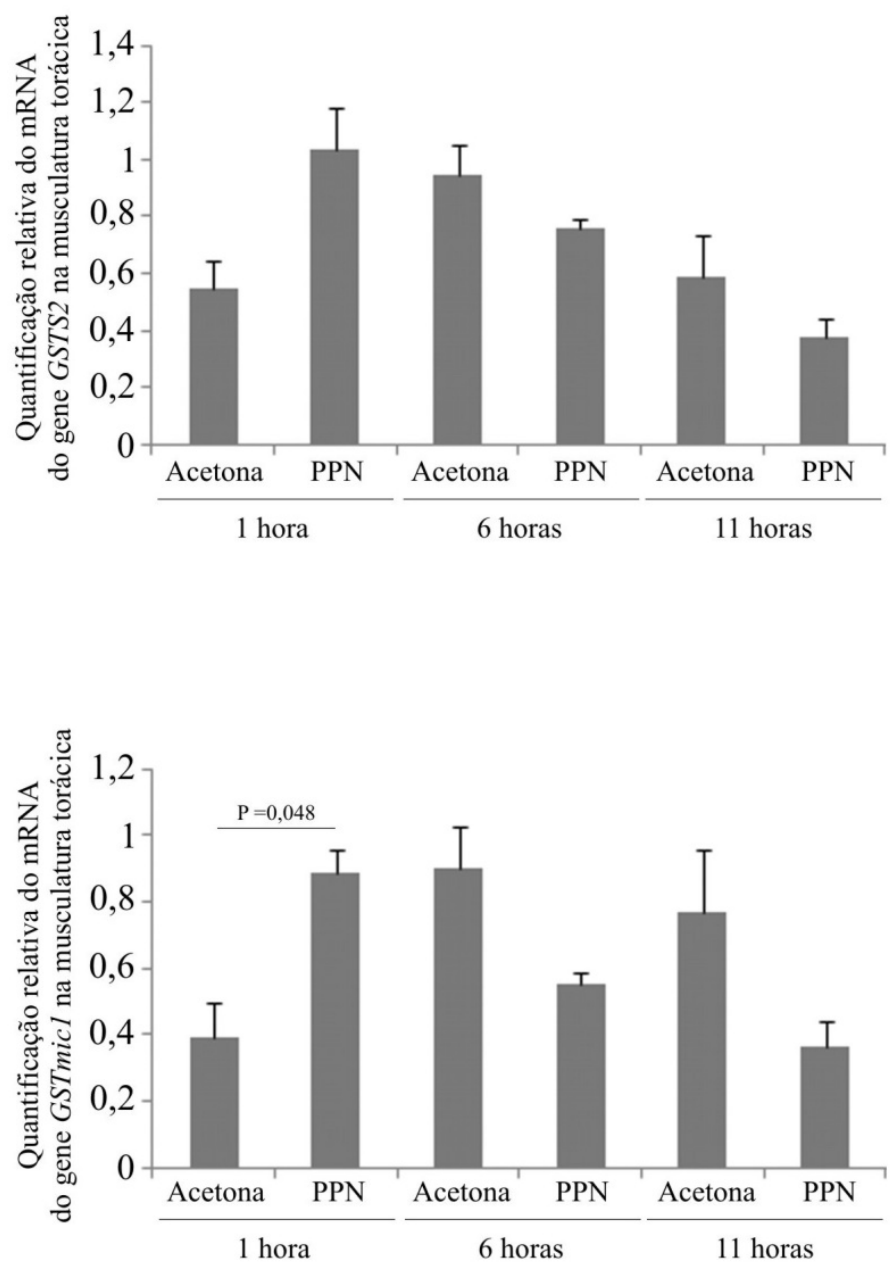

Figura 11 - Padrões de expressão dos genes GSTS2 e GSTmic1 na musculatura torácica de operárias de A. mellifera tratadas com $10 \mu \mathrm{g}$ de PPN diluído em acetona, ou somente com acetona (controles) decorridos 1, $6 \mathrm{e}$ 11 horas entre o tratamento e a coleta do tecido muscular. A) RT-PCR semiquantitativa: transcrição reversa e amplificação do cDNA, seguida de eletroforese em gel de agarose corado com brometo de etídeo. O gene de expressão constitutiva, rp49, foi utilizado como normalizador da RT-PCR. B) Quantificação relativa usando densitometria. Os níveis de transcritos são estatisticamente diferentes entre os grupos quando $\mathrm{P}<0,050$ (two-way ANOVA; Jandel SigmaStat 3.1 software, Jandel Corporation, USA). 
Desta forma, os dados obtidos não discerniram diferenças significantes nos níveis de transcritos de GSTS2 e GSTmic1 no corpo gorduroso parietal das abelhas tratadas com PPN, em relação às controles, nos tempos de 1, 6 e 11 horas após o tratamento. No entanto, na musculatura torácica observou-se tendência de aumento de expressão de ambos os genes no tempo de 1 hora após o tratamento. Este resultado, no entanto, tem que ser considerado com reserva e exige novos experimentos para verificação.

\subsection{Busca por genes codificadores de HP19 no genoma de $A$. mellifera}

A sequência de nucleotídeos do gene codificador de HP19 de C. cephalonica (Arif et al., 2004) foi utilizada para a localização de sequências homólogas no genoma de A. mellifera. Esta busca mostrou que dois dos genes codificadores de GSTs, GSTS1 e GSTS4, mostravam as maiores similaridades com o gene hp19 de C. cephalonica. As sequências de aminoácidos deduzidas de GSTS1 e GSTS4 foram acessadas in silico através do programa Expasy (http://web.expasy.org/translate/) e, em seguida, foram alinhadas com a sequência de aminoácidos de HP19 utilizando-se ClustalW (Fig. 12). A análise mostrou similaridade de $35 \%$ e $36 \%$ entre as sequências primárias das proteínas codificadas por GSTS1 e GSTS4, respectivamente, e a HP19 de C. cephalonica. A similaridade entre as sequências primárias das proteínas deduzidas de GSTS1 e GSTS4 de A. mellifera é de 46\%.

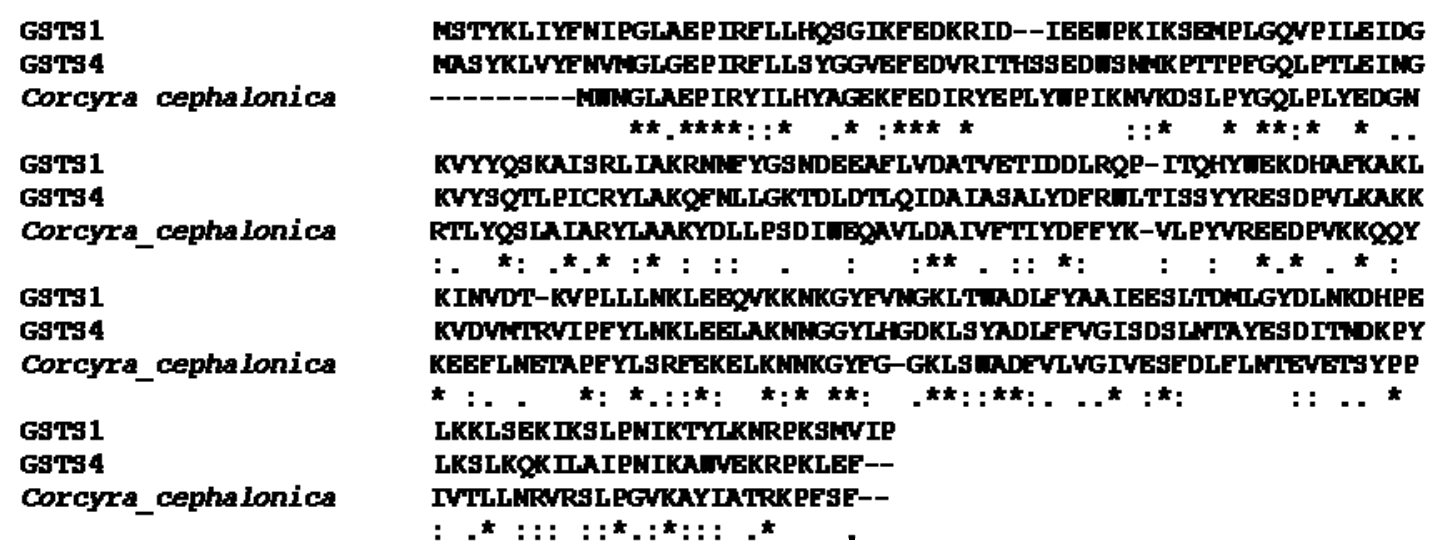

Figura 12 - Alinhamento das sequências de aminoácidos deduzidas de GSTS1 (ACP39962) e GSTS4 (ACJ12596) de A. mellifera com a proteína HP19 de C. cephalonica (Arif et al., 2004). (*) aminoácidos idênticos; (.) e (:) resíduos conservados.

A partir desta análise os genes GSTS1 e GSTS4 de A. mellifera foram denominados $h p 19^{1}\left(\right.$ GSTS1) e $h p 19^{2}$ (GSTS4), respectivamente. 


\subsection{Expressão dos genes $h p 19^{1}$ (GSTS1) e $h p 19^{2}$ (GSTS4) em diferentes tecidos e}

durante o desenvolvimento de A. mellifera

Foi procedida à caracterização da expressão dos genes $h p 19^{1}$ (GSTS1) e $h p 19^{2}$ (GSTS4) utilizando RT-PCR semiquantitativa seguida de análise em géis de agarose corados com brometo de etídio.

Foram utilizados o intestino posterior, o corpo gorduroso parietal e o visceral de abelhas operárias, em fase de adulta-farata, nas primeiras tentativas de identificar transcritos de $h p 19^{1}$ (GSTS1) e $h p 19^{2}$ (GSTS4). Níveis mais elevados de ambos transcritos foram detectados no intestino posterior e no corpo gorduroso visceral em detrimento do corpo gorduroso parietal (Fig. 13).

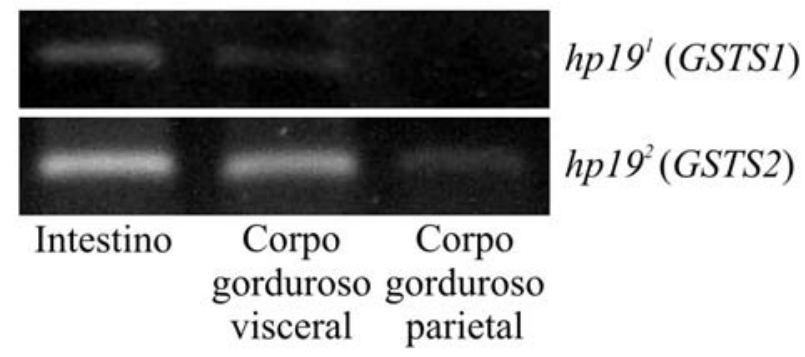

Figura 13 - Expressão dos genes $h p 19^{1}$ (GSTS1) e $h p 19^{2}$ (GSTS4) no intestino e no corpo gorduroso visceral e parietal de operárias de $A$. mellifera em fase de adulta-farata.

Devido à presença de níveis mais elevados de transcritos no intestino posterior e corpo gorduroso visceral, estes tecidos foram utilizados para os estudos de expressão nas diferentes fases do desenvolvimento de A. mellifera.

No intestino posterior de operárias em desenvolvimento, os transcritos do gene hp191 (GSTS1) foram detectados em larvas de $5^{\circ}$ instar em fase de tecelagem do casulo (fases $\mathrm{S}_{1}, \mathrm{~S}_{2}$ e $\mathrm{S}_{3}$ ) e em adultas-faratas que já iniciaram a pigmentação do exoesqueleto (fase $\mathrm{Pbl}$ ), mantendo-se praticamente indetectáveis em pré-pupas (ou pupas-faratas) (PP), pupas (Pw) e adultas-faratas iniciais, ainda não pigmentadas (Pp) (Fig. 14). 


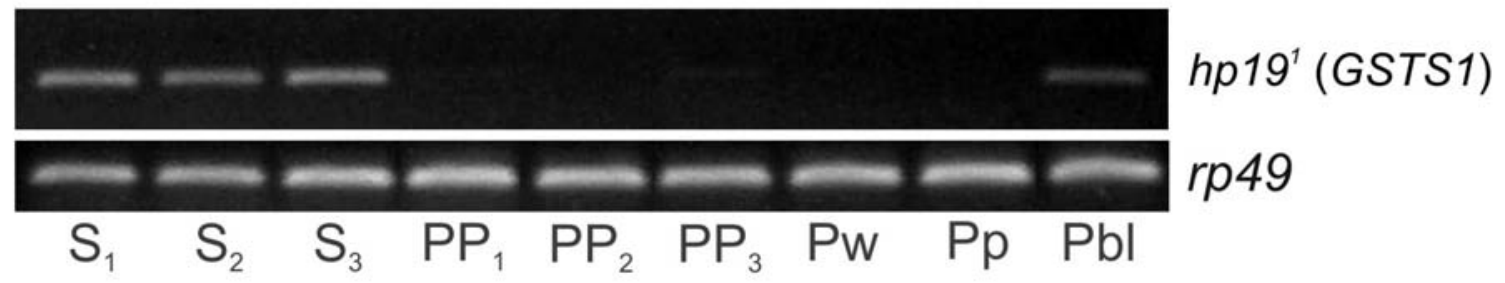

Figura 14 - Padrão de expressão do gene $h p 19^{1}($ GSTS1) no intestino posterior ao longo do desenvolvimento de operárias de A. mellifera. RT-PCR semiquantitativa: transcrição reversa e amplificação do cDNA, seguida de eletroforese em gel de agarose corado com brometo de etídeo. O gene de expressão constitutiva, rp49, foi utilizado como normalizador da RT-PCR. $\mathrm{S}_{1}, \mathrm{~S}_{2}, \mathrm{~S}_{3}$ : fases sucessivas de tecelagem do casulo, $5^{\circ}$ instar larval; $\mathrm{PP}_{1}, \mathrm{PP}_{2}$ e $\mathrm{PP}_{3}$ : fases sucessivas de pupa-farata; $\mathrm{Pw}$ : pupa; $\mathrm{Pp}$ e $\mathrm{Pbl}$ : fases inicial e intermediáriade adulta-farata.

O padrão de expressão do gene $h p 19^{2}$ (GSTS4) no intestino posterior difere consideravelmente daquele observado para o gene $h p 19^{1}$ (GSTS1), neste órgão. Os níveis de transcritos de $h p 19^{2}$ (GSTS4) são relativamente baixos em larvas em fase de tecelagem de casulo (fases $\mathrm{S}_{2}$ e $\mathrm{S}_{3}$ ), mas subsequentemente aumentam em pupas-faratas (fases $\mathrm{PP}_{1}, \mathrm{PP}_{2}$, $\mathrm{PP}_{3}$ ), pupas ( $\mathrm{Pw}$ ), e adultas-faratas iniciais (fase $\mathrm{Pp}$ ) e intermediárias (fase Pbl) (Fig. 15).

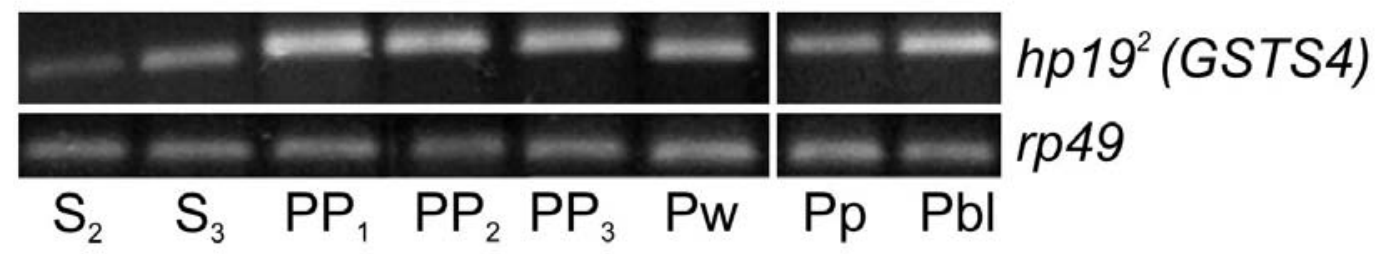

Figura 15 - Padrão de expressão do gene $h p 19^{2}$ (GSTS4) no intestino posterior ao longo do desenvolvimento de operárias de A. mellifera. RT-PCR semiquantitativa: transcrição reversa e amplificação do cDNA, seguida de eletroforese em gel de agarose corado com brometo de etídeo. O gene de expressão constitutiva, rp49, foi utilizado como normalizador da RT-PCR. $\mathrm{S}_{1}$ e $\mathrm{S}_{2}$ : fases sucessivas de tecelagem do casulo, $5^{\circ}$ instar larval; $\mathrm{PP}_{1}$, $\mathrm{PP}_{2}$ e $\mathrm{PP}_{3}$ : fases sucessivas de pupa-farata; $\mathrm{Pw}$ : pupa; $\mathrm{Pp}$ e Pbl: fases inicial e intermediária de adulta-farata.

Assim, o padrão de expressão do gene $h p 19^{1}$ (GSTS1) no intestino durante o desenvolvimento difere do padrão de expressão do gene $h p 19^{2}$ (GSTS4) neste órgão. Ressaltese a interrupção da transcrição durante a muda metamórfica. Este resultado condiz com a hipótese de que a inibição de $h p 19^{1}$ (GSTS1) permite a ativação do receptor de hexamerinas e o consequente sequestro destas proteínas, o qual tem início durante a muda metamórfica.

No corpo gorduroso visceral de operárias em desenvolvimento, os transcritos do gene $h p 19^{1}$ (GSTS1) foram detectados em larvas de $5^{\circ}$ instar em fase inicial de tecelagem do casulo $\left(\mathrm{S}_{1}\right)$ e em adultas-faratas $(\mathrm{Pbl})$. Os transcritos são praticamente ausentes nas fases 
intermediária e final de tecelagem do casulo $\left(\mathrm{S}_{2}\right.$ e $\left.\mathrm{S}_{3}\right)$, nas fases de pupas-faratas $\left(\mathrm{PP}_{1}, \mathrm{PP}_{2}\right.$ e $\left.\mathrm{PP}_{3}\right)$, nas pupas $(\mathrm{Pw})$ e nas adultas-faratas iniciais $(\mathrm{Pp})$ (Fig. 16).

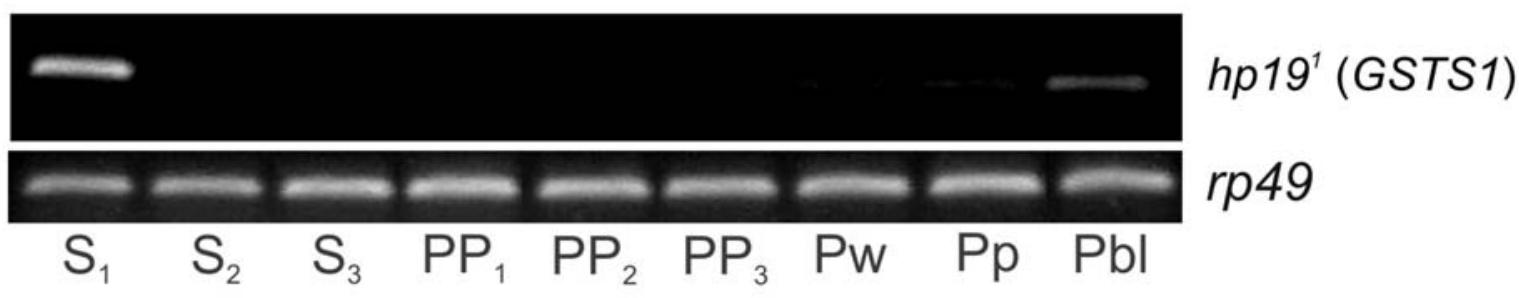

Figura 16 - Padrão de expressão do gene $h p 19^{1}(G S T S 1)$ no corpo gorduroso visceral ao longo do desenvolvimento de operárias de A. mellifera. RT-PCR semiquantitativa: transcrição reversa e amplificação do cDNA, seguida de eletroforese em gel de agarose corado com brometo de etídeo. O gene de expressão constitutiva, rp49, foi utilizado como normalizador da RT-PCR. $\mathrm{S}_{1}, \mathrm{~S}_{2}, \mathrm{~S}_{3}$ : fases sucessivas de tecelagem do casulo, $5^{\circ}$ instar larval; $\mathrm{PP}_{1}, \mathrm{PP}_{2}$ e $\mathrm{PP}_{3}$ : fases sucessivas de pupa-farata; $\mathrm{Pw}$ : pupa; $\mathrm{Pp}$ e Pbl: fases inicial e intermediária de adulta-farata.

Os transcritos do gene $h p 19^{2}$ (GSTS4) foram detectados no corpo gorduroso visceral de operárias em todas as fases do desenvolvimento analisadas, embora baixos níveis tenham sido detectados em larvas de $5^{\circ}$ instar em fase inicial $\left(\mathrm{S}_{1}\right)$ ou intermediária $\left(\mathrm{S}_{2}\right)$ de tecelagem do casulo (Fig. 17).
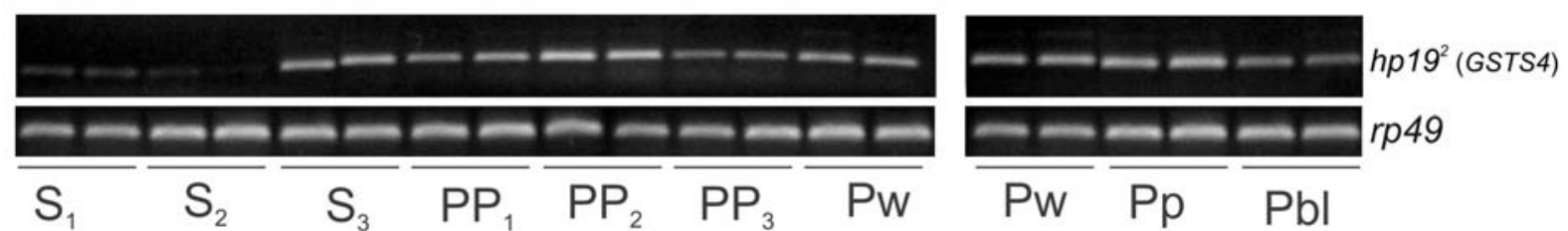

Figura 17 - Padrão de expressão do gene $h p 19^{2}$ (GSTS4) no corpo gorduroso visceral ao longo do desenvolvimento de operárias de A. mellifera. RT-PCR semiquantitativa: transcrição reversa e amplificação do cDNA, seguida de eletroforese em gel de agarose corado com brometo de etídeo. O gene de expressão constitutiva, rp49, foi utilizado como normalizador da RT-PCR. $\mathrm{S}_{1}, \mathrm{~S}_{2}, \mathrm{~S}_{3}$ : fases sucessivas do $5^{\circ}$ instar larval tecelagem do casulo; $\mathrm{PP}_{1}, \mathrm{PP}_{2}$ e $\mathrm{PP}_{3}$ : fases sucessivas de pupa-farata; $\mathrm{Pw}$ : pupa; $\mathrm{Pp}$ e $\mathrm{Pbl}$ : fases sucessivas de adulta-farata.

Portanto, no corpo gorduroso visceral o padrão de expressão do gene $h p 19^{1}$ (GSTS1) (Fig. 16) difere do padrão de expressão do gene $h p 19^{2}$ (GSTS4) (Fig. 17). Mas, os perfis de expressão de cada um destes genes mostraram-se similares nos dois tecidos estudados, como se pode depreender da comparação entre as Figs. 14 e 16 e da comparação entre as Figs. 15 e 17. 


\subsection{Efeito de 20E e de PPN na expressão dos genes $h p 19^{1}$ (GSTS1) e $h p 19^{2}$ (GSTS4) $^{\text {(GST }}$}

no intestino posterior de larvas e pupas/adultas-faratas

O modelo a ser testado pressupõe que o aumento do nível de ecdisteróides que precede a muda metamórfica coincide com a inibição da ação da proteína HP19. Estas ocorrências induziriam o sequestro de proteínas de estocagem (hexamerinas) da hemolinfa pelo corpo gorduroso: um evento marcante da metamorfose. Com base nesta premissa foi investigada a expressão dos genes $h p 19^{1}$ (GSTS1) e $h p 19^{2}$ (GSTS4), que codificariam possíveis proteínas HP19, em larvas e pupas/adultas-faratas tratadas com o ecdisteróide 20E. Visto que a muda depende também de hormônio juvenil (HJ) que age sinergicamente com os ecdisteróides, foi utilizado um análogo sintético de HJ, PPN, em testes paralelos.

Nas larvas os tratamentos foram realizados com o objetivo de verificar se a alteração do programa normal da metamorfose, provocada pelos tratamentos, alteraria também os níveis de transcritos de $h p 19^{1}$ (GSTS1) e $h p 19^{2}$ (GSTS4). Nas pupas/adultas-faratas os tratamentos visaram analisar o efeito dos hormônios na expressão destes genes após a muda metamórfica.

\subsubsection{Efeito do tratamento hormonal em larvas}

As larvas foram tratadas com $20 \mathrm{E}$ em um momento (início do $5^{\circ}$ instar, fase $\mathrm{F}_{1}$ ) em que o título de ecdisteróides na hemolinfa é basal (Rachinsky et al., 1990). O tratamento visou antecipar a elevação do título de ecdisteróides que, normalmente, só ocorre após a fase $\mathrm{S}_{3}$ (Fig. 18A). Os resultados mostraram que os níveis de transcritos de $h p 19^{1}$ (GSTS1) e $h p 19^{2}$ (GSTS4) no intestino de larvas tratadas com 20E, e coletadas na fase $\mathrm{F}_{3}$, foram superiores aos níveis detectados no intestino das larvas do grupo controle (Fig. 18B). 


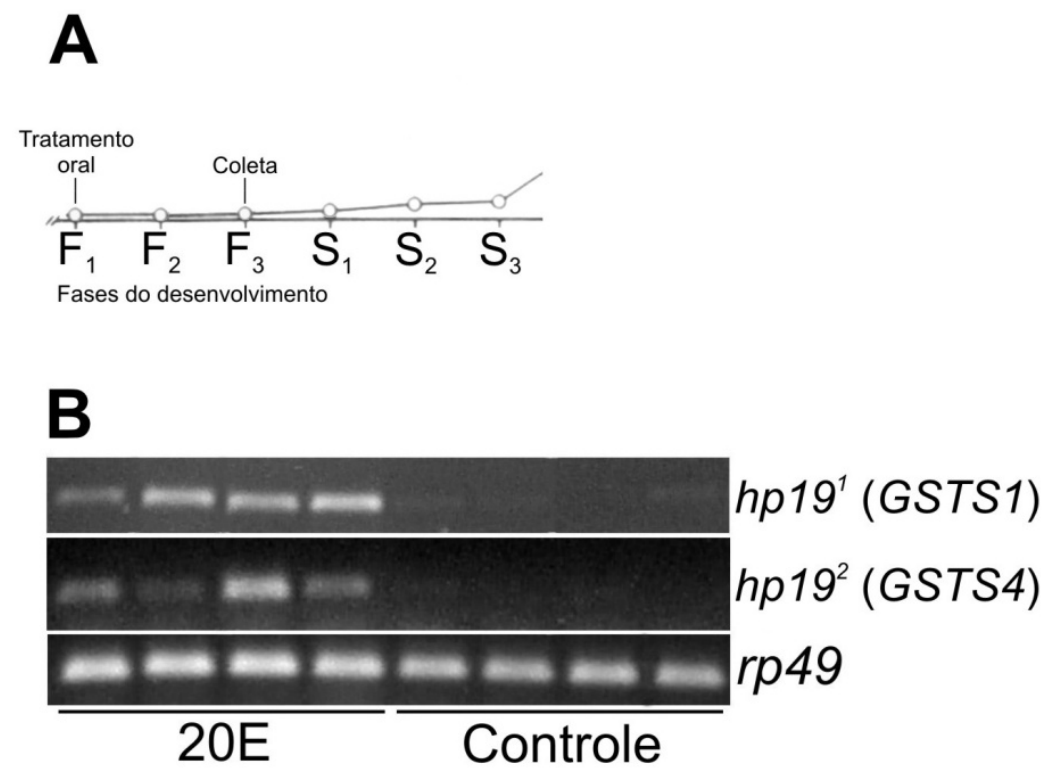

Figura 18 - Efeito do tratamento com 20E (diluído em etanol em salina de Ringer) nos níveis de transcritos dos genes $h p 19^{1}$ (GSTS1) e $h p 19^{2}$ (GSTS4) no intestino de larvas de operárias. A) Curva do título de 20E na hemolinfa de larvas de $5^{\circ}$ instar de operárias (segundo Rachinsky et al., 1990). Os momentos do tratamento oral e coleta do intestino estão indicados. B) RT-PCR semiquantitativa: transcrição reversa e amplificação do cDNA, seguida de eletroforese em gel de agarose corado com brometo de etídeo. As amostras foram analisadas 24 horas após o tratamento. Controles receberam somente etanol em salina de Ringer. O gene de expressão constitutiva, $r p 49$, foi utilizado como normalizador da RT-PCR.

$\mathrm{O}$ HJ foi administrado às larvas em um momento em que o título deste hormônio normalmente decai na hemolinfa (Rachinsky et al., 1990), visando desta forma manter o alto título destes análogos (Fig. 19A). Os resultados destes experimentos mostraram que os níveis de transcritos de $h p 19^{1}$ (GSTS1) nas amostras de intestino de larvas tratadas com HJ também foram superiores aos níveis detectados nas amostras controle. Já os níveis de transcritos do gene $h p 19^{2}$ (GSTS4) não diferiram entre os grupos tratado e controle (Fig. 19B). 


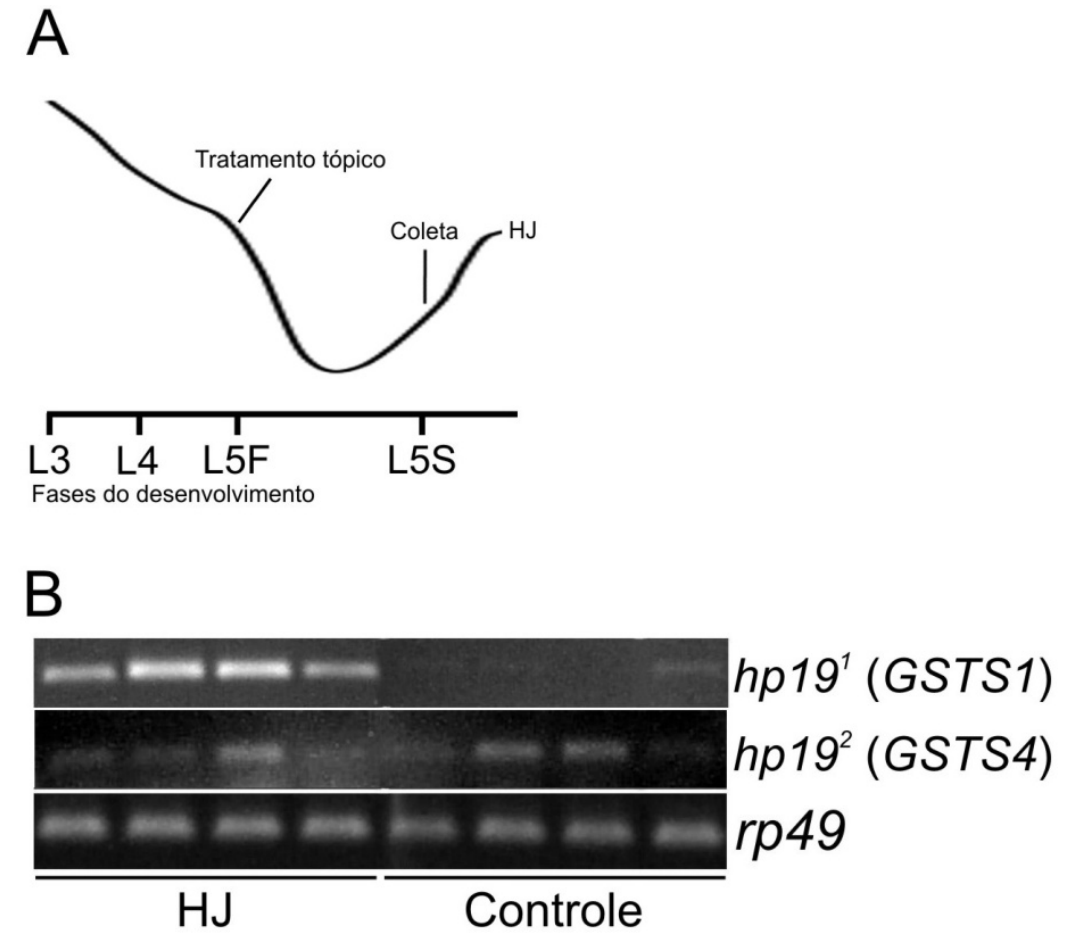

Figura 19 - Efeito do tratamento com HJ (diluído em acetona) nos níveis de transcritos dos genes $h p 19^{1}$ (GSTS1) e $h p 19^{2}$ (GSTS4) no intestino de larvas de operárias. A) Curva do título de HJ na hemolinfa de larvas de $5^{\circ}$ instar de operárias (segundo Rachinsky et al., 1990). Os momentos do tratamento tópico e coleta do intestino estão indicados. B) RT-PCR semiquantitativa: transcrição reversa e amplificação do cDNA, seguida de eletroforese em gel de agarose corado com brometo de etídeo. As amostras foram analisadas 24 horas após o tratamento. Controles receberam somente acetona. O gene de expressão constitutiva, $r p 49$, foi utilizado como normalizador da RT-PCR.

Portanto, o tratamento oral com 20E induziu a expressão de ambos os genes, hp191(GSTS1) e $h p 19^{2}$ (GSTS4), no intestino posterior de larvas de operárias. O tratamento tópico com HJ também induziu a expressão de $h p 19^{1}$ (GSTS1), mas não modificou a expressão de $h p 19^{2}$ (GSTS4) no intestino larval.

\subsubsection{Efeito do tratamento hormonal em pupas/adultas-faratas}

O tratamento de pupas/adultas-faratas com 20E foi realizado em um momento em que, normalmente, o título deste hormônio está decaindo (segundo Pinto et al., 2000), assim visando manter altos níveis de hormônio no organismo (Fig. 20A). O tratamento provocou o típico efeito descrito por Zufelato et al., (2000), ou seja, desaceleração do processo de desenvolvimento da abelha adulta-farata. Isto pôde ser evidenciado pelo aspecto menos pigmentado do exoesqueleto e dos olhos das abelhas tratadas com 20E (Fig. 20B). As análises por RT-PCR semiquantitativa utilizando-se RNA extraído do intestino sugeriram aumento da expressão do gene $h p 19^{1}$ (GSTS1) em decorrência da injeção de 20E (diluído em etanol em 
salina de Ringer) em comparação com os controles, injetados somente com o diluente de 20E. A expressão do gene $h p 19^{2}$ (GSTS4) não foi modificada com o tratamento (Fig. 20C). A indução da expressão de $h p 19^{1}$ (GSTS1) por 20E foi corroborada por análise por RT-PCR em Tempo Real utilizando as mesmas amostras de RNA de intestino (Fig. 20D): houve aumento significante da quantidade relativa destes transcritos nos intestinos de abelhas tratadas com 20E em relação aos controles $(\mathrm{P}<0,007$, Teste-t, Jandel SigmaStat 3.1 software, Jandel Corporation, USA). 


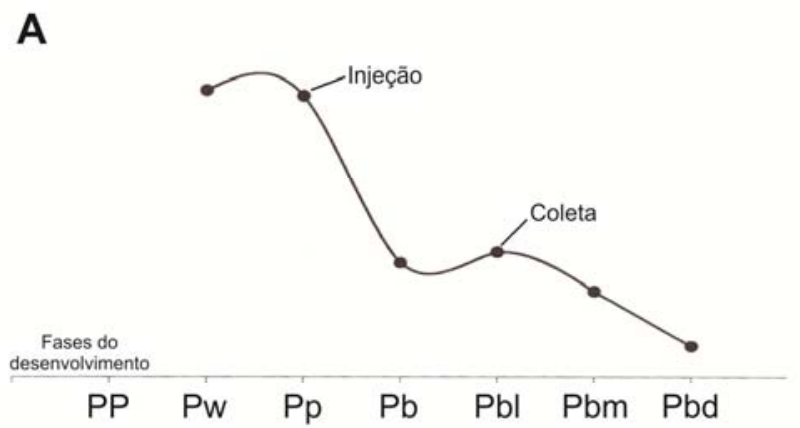

B

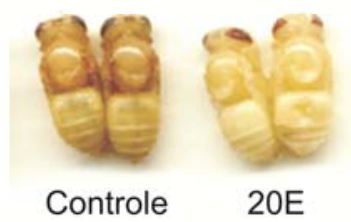

C

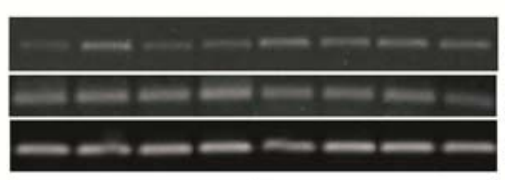

hp19 (GSTS1)

hp1 $19^{2}$ (GSTS4)

rp49

Controle

$20 \mathrm{E}$

D

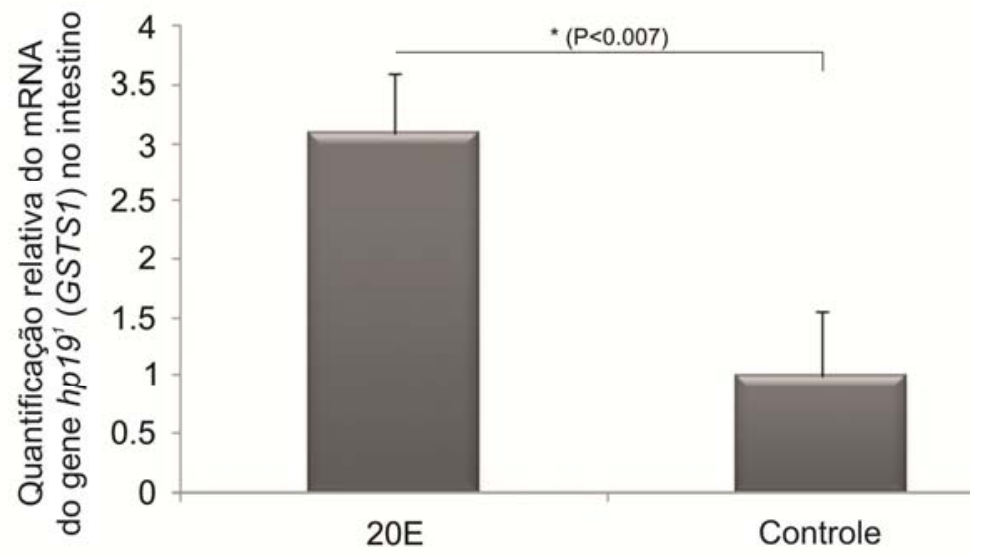

Figura 20 - Efeito do tratamento com 20E na expressão dos genes hp191 (GSTS1) e hp19²(GSTS4) no intestino de operárias adultas-faratas. A) Curva do título de hormônio 20E na hemolinfa ao longo do desenvolvimento pupal e adulto-farato de operárias de A. mellifera (segundo Pinto et al., 2000).Os momentos de injeção do hormônio e coleta do intestino estão indicados. B) Aspecto das operárias adultas-faratas 5 dias após a injeção de $20 \mathrm{E}$ (diluído em etanol em salina de Ringer) e respectivos controles, injetados com etanol em salina de Ringer. C) RT-PCR semiquantitativa utilizando-se amostras de RNA de intestino de adultas-faratas, tratadas com $20 \mathrm{E}$ e controles. Eletroforese em gel de agarose corado com brometo de etídeo. O gene de expressão constitutiva, rp49, foi utilizado como normalizador da RT-PCR. D) Quantificação relativa dos transcritos de $h p 19^{1}$ (GSTS1) no intestino por meio de RT-PCR em tempo real. O gene rp49 foi utilizado como normalizador. A quantidade relativa de transcritos foi calculada segundo o método $2^{-\Delta \Delta C t}$. A média dos valores (triplicatas de pools preparados com 5 intestinos) obtida de operárias tratadas com $20 \mathrm{E}$ foi calculada em relação à média dos controles, à qual foi atribuído o valor 1 . Os níveis de transcritos são estatisticamente diferentes entre os grupos $(\mathrm{P}<0.007$; teste-t; Jandel SigmaStat 3.1 software, Jandel Corporation, USA). 
O título de HJ é basal durante todo o estágio pupal e adulto-farato de A. mellifera (Rembold, 1987b) e de insetos holometábolos em geral. O tratamento com PPN foi realizado com o objetivo de verificar se os genes $h p 19^{1}$ (GSTS1) e $h p 19^{2}$ (GSTS4) respondem a este análogo de HJ (Fig. 21A). O tratamento causou as já relatadas (Zufelato et al., 2000) alterações fenotípicas nas operárias adultas-faratas, as quais apresentaram intensificação precoce da pigmentação, principalmente do exoesqueleto da cabeça e tórax. (Fig. 21B). Estas alterações comprovam o efeito biológico do PPN. A expressão do gene $h p 19^{1}$ (GSTS1) aumentou em decorrência do tratamento com este análogo do HJ (Fig. 21C). Mas os níveis de transcritos do gene $h p 19^{2}$ (GSTS4) não foram modificados pelo tratamento (Fig. 21C).

\section{A}

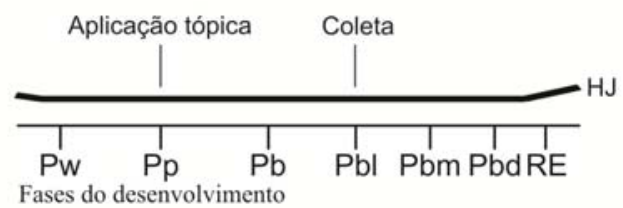

B

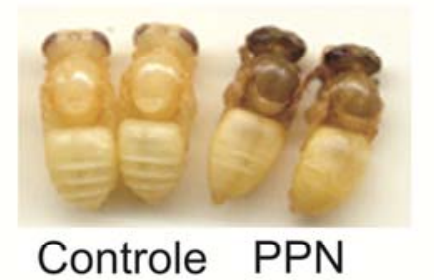

C

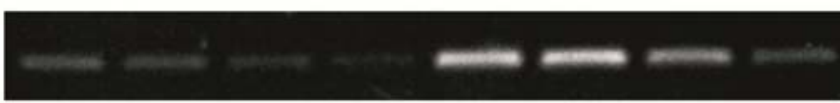
$h p 19^{1}$ (GSTS1)

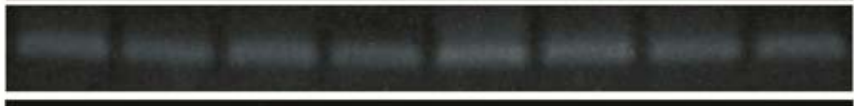
$h p 19^{2}$ (GSTS4)

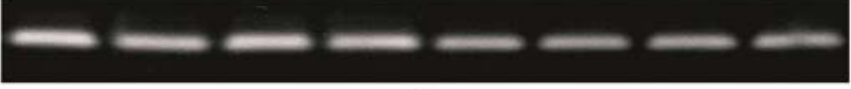
rp49

Controle

PPN

Figura 21 - Efeito do tratamento com PPN nos níveis de transcritos dos genes $h p 19^{1}$ (GSTS1) e $h p 19^{2}$ (GSTS4) no intestino de operárias adultas-faratas. A) Títulos de hormônio juvenil ao longo do desenvolvimento pupal e adulto-farato de operárias de A. mellifera (segundo Rembold, 1987). Os momentos de aplicação tópica de PPN e coleta do intestino estão identificados. B) Aspecto das operárias adultas-faratas 5 dias após a aplicação tópica de PPN (diluído em acetona), e respectivos controles que receberam somente acetona topicamente. C) RT-PCR semiquantitativa utilizando-se amostras de RNA de intestino de adultas-faratas, tratadas ou não com PPN. Eletroforese em gel de agarose corado com brometo de etídeo. O gene de expressão constitutiva, rp49, foi utilizado como normalizador da RT-PCR. 
Assim, em intestinos de pupas/adultas-faratas, os tratamentos com $20 \mathrm{E}$ ou PPN induziram aumento dos níveis de transcritos do gene $h p 19^{1}$ (GSTS1), mas não modificaram a expressão do gene $h p 19^{2}$ (GSTS4).

\subsection{Silenciamento gênico pós-transcricional de $h p 19^{1}$ (GSTS1)}

Os efeitos consistentes de 20E e PPN sobre a expressão do gene $h p 19^{1}$ (GSTS1) sugeriram função no processo de metamorfose. Para investigar esta hipótese foram realizados experimentos de silenciamento gênico pós-transcricional adicionando-se diferentes concentrações de dsRNA na alimentação larval. Os tratamentos, principalmente com 10 e 20 $\mu \mathrm{g}$ de dsRNA, resultaram em níveis de transcritos muito mais baixos que os dos controles (Fig. 22).

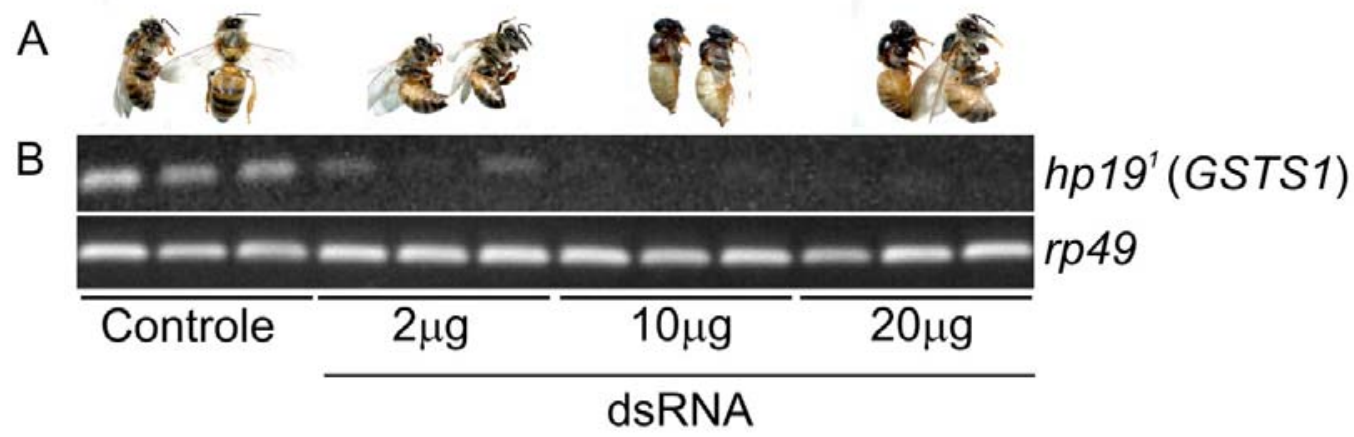

Figura 22 - Efeito de diferentes concentrações de dsRNA contra $h p 19^{1}$ (GSTS1) ministrado no alimento a larvas de $4^{\circ}$ instar. A) Aspecto das abelhas operárias que se alimentaram com dsRNA, ou não (controles), no dia previsto para a emergência como adultos. B) RT-PCR semiquantitativa: transcrição reversa e amplificação do cDNA, seguida de eletroforese em gel de agarose corado com brometo de etídeo. O gene de expressão constitutiva, rp49, foi utilizado como normalizador da RT-PCR.

Com base nestes resultados, foram utilizadas $15 \mu \mathrm{g}$ de dsRNA em um adicional experimento de silenciamento do gene $h p 19^{1}$ (GSTS1) com a finalidade de investigar o efeito sobre a dinâmica de sequestro de uma hexamerina pelo corpo gorduroso durante a metamorfose. Das 27 larvas tratadas com dsRNA apenas 5 não mostraram knockdown da expressão do gene $h p 19^{1}$ (GSTS1) no intestino, sendo a eficiência do tratamento de $81,5 \%$. O efeito do dsRNA pôde ser conferido nas amostras analisadas por RT-PCR semiquantitativa (Fig. 23A, Apêndice 2). O menor nível de transcritos no intestino do grupo de abelhas alimentadas com o dsRNA em relação ao grupo controle foi verificado por densitometria (Fig. 23B). 
O silenciamento resultou em mortalidade de $60,42 \%(n=27)$ das larvas que se alimentaram com o dsRNA, e de 18,75\% das larvas $(n=9)$ do grupo controle (Fig. 23C). Ao final do tratamento, as larvas alimentadas com dsRNA apresentavam peso significativamente inferior às do grupo controle $(\mathrm{P}=<0,001$; teste-t) (Fig. 23D). Estes dados indicam que o silenciamento implica em sérios danos para o desenvolvimento.

As análises do perfil de expressão da hexamerina HEX 70a na hemolinfa por meio de SDS-PAGE e Western blot revelaram redução dos níveis desta proteína nas larvas alimentadas com o dsRNA em relação ao grupo controle (Fig. 23E, Apêndice 2). A densitometria das bandas obtidas nos Western blots confirmaram este resultado $(\mathrm{P}=0,002$; teste-t) (Fig. 23F). Estes dados permitem sugerir que o silenciamento do gene $h p 19^{1}$ (GSTS1) contribui para a remoção, ou sequestro, de HEX 70a da hemolinfa pelo corpo gorduroso. 

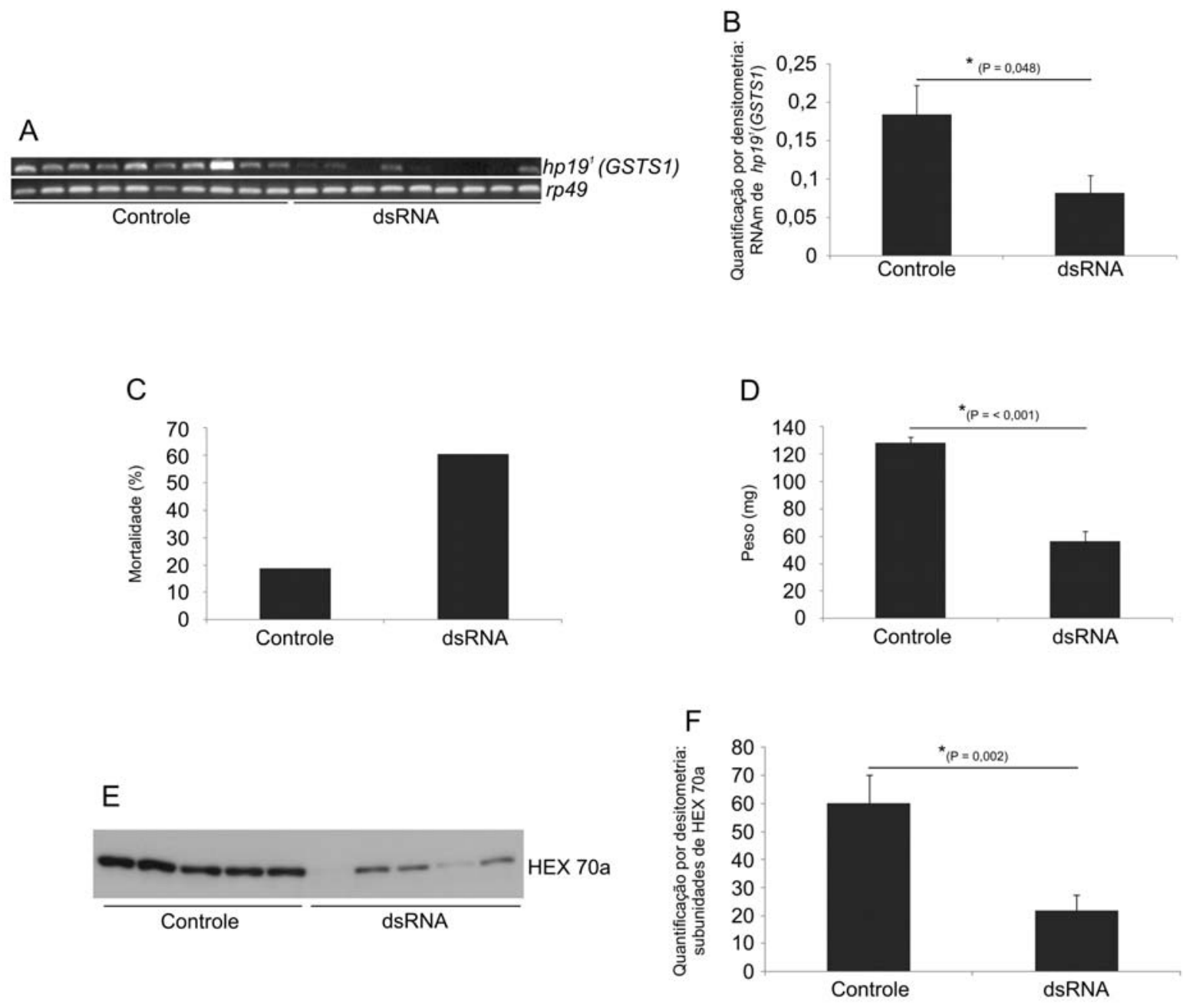

Figura 23 - Efeito do dsRNA para silenciamento do gene $h p 19^{1}$ (GSTS1) sobre o teor de hexamerinas HEX 70a na hemolinfa. A) Knockdown da expressão de $h p 19^{1}$ (GSTS1) em larvas alimentadas com $15 \mu \mathrm{g}$ de dsRNA. Controles: larvas de idade correspondente que não receberam dsRNA no alimento. RT-PCR semiquantitativa: transcrição reversa e amplificação do cDNA, seguida de eletroforese em gel de agarose corado com brometo de etídeo. O gene de expressão constitutiva, rp49, foi utilizado como normalizador da RT-PCR. B) Densitometria para quantificação de transcritos $h p 19^{1}$ (GSTS1) evidenciados por RT-PCR semi-quantitativa. C) Mortalidade e D) Peso Médio das larvas alimentadas com dsRNA versus controles. E) SDS-PAGE e Western blot para detecção de HEX 70a na hemolinfa. F) Densitometria das bandas obtidas nos Western blots para quantificação de HEX 70a na hemolinfa. Diferença estatisticamente significante entre tratados e controles foi determinada usando teste-t (Jandel SigmaStat 3.5 software, Jandel Corporation, USA).

A alimentação de larvas de operárias com dsRNA foi efetiva para o knockdown do gene $h p 19^{1}$ (GSTS1), ou seja, os níveis de transcritos no intestino destas larvas diminuíram significantemente quando comparados com os do grupo controle. Paralelamente foi observado redução estatisticamente significante do teor de proteínas HEX 70a na hemolinfa das larvas alimentadas com dsRNA, sugerindo que o processo de remoção destas proteínas da hemolinfa, que ocorre naturalmente durante a metamorfose, depende da inibição do gene hp19 ${ }^{1}$ (GSTS1). 
O knockdown, porém, foi transitório. Os níveis de expressão do gene $h p 19^{1}$ (GSTS1) no intestino de abelhas alimentadas com dsRNA se mostraram iguais ou até superiores aos das controles quando as larvas sobreviventes atingiram a fase $\mathrm{Pbl}$ do desenvolvimento adultofarato. (Fig. 24).

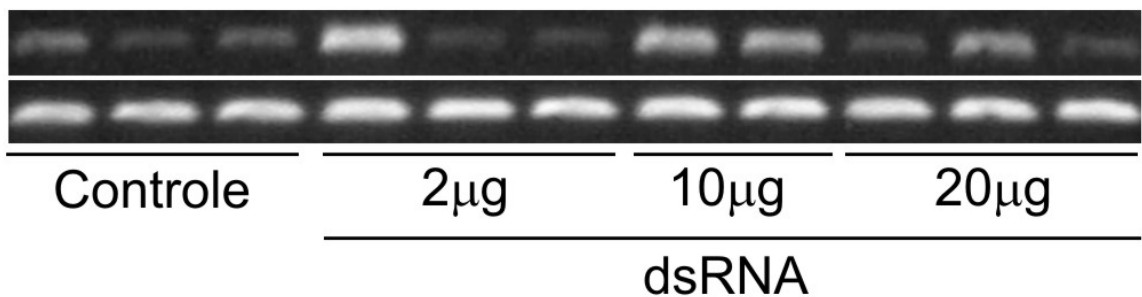

hp191 (GSTS1) rp49

Figura 24 - Padrão de expressão do gene $h p 19^{1}$ (GSTS1) no intestino de operárias adultas-faratas, em fase Pbl, alimentadas com dsRNA durante o $4^{\circ}$ instar larval. Controles: adultas-faratas de idade correspondente que não receberam dsRNA no alimento. RT-PCR semiquantitativa: transcrição reversa e amplificação do cDNA, seguida de eletroforese em gel de agarose corado com brometo de etídeo. O gene de expressão constitutiva, rp49, foi utilizado como normalizador da RT-PCR.

Pode-se então notar que a expressão do gene $h p 19^{1}$ (GSTS1) foi recuperada, isto é, igualou-se à dos controles, em $50 \%(\mathrm{n}=8)$ das adultas-faratas alimentadas com as diferentes doses de dsRNA durante o $4^{\circ}$ instar larval. Inexplicavelmente, nos 50\% $(n=8)$ restantes, a expressão de $h p 19^{1}$ (GSTS1) foi induzida. 


\section{DISCUSSÃO}

\subsection{Sequenciamento e análise dos genes codificadores de GSTs}

Dez genes potencialmente funcionais de Glutationa S-transferase (GST) foram encontrados no genoma de A. mellifera (Claudianos et al., 2006), e receberam as seguintes denominações e números de acesso (entre parênteses) no Honey bee genome sequences assembly (http://www.hgsc.bcm.tmc.edu/projects/honeybee/ - versão 4.0): GSTS1 (GB16959), GSTS2 (GB30268), GSTS3 (GB19254), GSTS4 (GB14372), GSTD1 (GB18045), GSTO1 (GB11466), GSTT1 (GB12047), GSTZ1 (GB17672), GST mic1 (GB12371) e GST mic2 (GB10566) (aqui denominado GST mic2/3). O sequenciamento de toda a região codificadora (CDS) e de parte das regiões não codificadoras (3'UTR e 5'UTR) de dois destes genes, GSTS1 e GSTS4, aqui re-nomeados $h p 19^{1}$ (GSTS1) e $h p 19^{2}$ (GSTS4), nos permitiu caracterizar suas respectivas estruturas. As CDSs dos outros oito genes foram parcialmente sequenciadas de modo que a estrutura gênica "inter-primers" pôde ser caracterizada, enquanto a estrutura das regiões não sequenciadas foram inferidas por meio de análises in silico com auxílio da plataforma Artemis 7.0 (Rutherford et al., 2000). Estes genes apresentam entre 2 a 5 éxons e possuem de 584 a 1969 nucleotídeos.

As proteínas putativamente codificadas por estes genes têm domínios típicos de glutationa S-transferases (domínios N e C e domínio de GST microssomal - MAPEG), indicando que pertencem a esta classe de enzimas. Em insetos, as glutationa S-transferases existem como dímeros (homodímeros ou heterodímeros) (Cohen, 1987; Cochrane et al., 1987; Grant \& Matsumura, 1988). Nesta conformação, ou seja, em estado nativo, a massa molecular destas enzimas foi estimada entre 38 e 60 kDa (Motoyama \& Dauterman, 1977, 1978; Cochrane et al., 1987; Toung et al., 1990, Arif et al., 2004), assim, a forma dimérica das GSTs estudadas teria massa molecular compatível com as glutationa S-transferases em geral, já que as massas moleculares das subunidades das GSTs de A. mellifera perfazem de 12,2 a 27,98 $\mathrm{kDa}$ (Apêndice 1).

\subsection{Expressão dos genes GSTs em tecidos de operárias forrageiras e nutridoras}

Nas colônias de A. mellifera, o polietismo etário, ou seja, a execução de diferentes tarefas pelas operárias conforme progridem em idade cronológica é uma característica muito 
evidente (Ament et al., 2008). Assim, operárias que saem da colônia para o forrageamento têm idade mais avançada que as operárias que permanecem na colônia e exercem a tarefa de alimentar as larvas. De acordo com a teoria do envelhecimento causado pelos radicais livres (Harman, 1956), com o aumento da idade aumenta o acúmulo de danos oxidativos causados por estes radicais presentes nos tecidos. De fato, a quantidade de espécies reativas de oxigênio, ou ROS (radicais livres) produzida nas forrageiras é maior que nas operárias nutridoras (Young \& Robinson, 1983). Em concordância, os níveis de expressão dos genes codificadores de enzimas antioxidantes, no caso as GSTs, nas abelhas forrageiras são maiores que no grupo das nutridoras, como foi possível demonstrar. Em sua maioria, os genes GSTs mostraram-se significativamente mais expressos em operárias forrageiras. Exceções foram os genes GSTS4 e GSTmic2/3 que não apresentaram diferença estatisticamente significante de expressão tanto no corpo gorduroso parietal quanto na musculatura de nutridoras e forrageiras, e os genes GSTS1 e GSTS3, cuja expressão não diferiu significantemente na musculatura torácica de nutridoras e forrageiras (compare a expressão destes genes nas Figs. 4 e 5$)$.

Assim, os níveis de expressão dos genes GSTs foram em geral maiores nas forrageiras em ambos os tecidos estudados, possivelmente com a finalidade de aumentar a produção de enzimas para transformação de produtos do estresse oxidativo, produzidos em grande quantidade nestas abelhas (Young \& Robinson, 1983).

\subsection{Expressão dos genes GSTs em tecidos de operárias alimentadas com} diferentes dietas

Um grama de geléia real tem 1,8 Kcal, um grama de pólen apresenta 2,44 Kcal e um grama de açúcar contém $4 \mathrm{Kcal}$, segundo informações nos rótulos destes produtos comercializados. Assim, as abelhas alimentadas com beebread (ou pólen processado pelas abelhas) diluído em xarope, ou geléia real diluída em xarope, ingeriram mais calorias do que aquelas alimentadas exclusivamente com xarope.

Sabe-se que a ingestão de dietas calóricas pode provocar aumento dos danos nos tecidos por espécies reativas de oxigênio (ROS) e assim causar estresse oxidativo (BruceKeller et al., 2010; Zhang et al., 2005). As GSTs inativam aldeídos insaturados, quinonas, epóxidos e hidroperóxidos formados como metabólitos secundários durante o estresse oxidativo. Mais uma informação é relevante neste contexto: as regiões promotoras dos genes codificadores de GSTs citosólicas e microssomais contêm elementos de resposta a 
antioxidantes pelos quais estes genes são transcricionalmente ativados durante a exposição ao estresse oxidativo (Hayes et al., 2005).

Foi verificado que os genes GSTS1, GSTS2, GSTS4 e GSTD1 apresentaram maior expressão no corpo gorduroso parietal de abelhas alimentadas com geléia real ou beebread diluídos em xarope em relação ao grupo alimentado somente com xarope, e que o gene GSTT1 também se mostrou mais expresso nas abelhas alimentadas com geléia real em detrimento daquelas que receberam somente xarope, e isto foi comprovado estatisticamente. Este resultado é consistente com a premissa de que o aumento do dano oxidativo provocado pela dieta induz a expressão de genes GSTs com consequente síntese das respectivas enzimas para inativação de compostos secundários derivados do estresse oxidativo. Ressalte-se que os outros 4 genes GSTs (GSTO1, GSTZ1, GSTmic1 e GSTmic2/3) também tenderam a ser mais expressos nas abelhas alimentadas com geléia real ou beebread, embora os níveis de transcritos entre estes grupos não tenham sido diferentes a ponto de serem discriminados pelos testes estatísticos.

Na musculatura torácica, os genes GSTS2, GSTS4, GSTT1 e GSTmic2/3 mostraram aumento de expressão estatisticamente significante em consequência da alimentação com geléia real e/ou beebread. Os outros genes GSTs (GSTS1, GSTD1, GSTO1, GSTZ1, GSTmic1) tenderam a ser mais expressos na musculatura torácica de abelhas alimentadas com geléia real e/ou beebread, contudo esta tendência não foi estatisticamente confirmada.

Note-se que as abelhas foram alimentadas com as diferentes dietas durante um período de 6 dias a contar da emergência. É possível que uma resposta mais contundente às diferentes condições nutricionais possa ser obtida se este período for estendido.

Junte-se à resposta dos genes GSTs às diferentes dietas a informação de que uma das propriedades da geléia real consiste em agir como agente antioxidante, diminuindo os radicais livres (Nagai et al., 2001; Guo et al., 2009; Cavusoglu et al., 2009). É possível que isto ocorra via indução de genes GSTs por componentes da geléia real. Neste caso, a ação destes genes seria parte de um mecanismo adaptativo que responde à ingestão de certos alimentos.

Continua inexplicada a ausência de atividade do gene GSTS3 em ambos os tecidos das abelhas alimentadas com as diferentes dietas durante 6 dias de confinamento em grupos, em pequenas caixas (ver Material e Métodos, item 3.1.3). Não foi obtido sucesso na amplificação de transcritos de GSTS3 destas abelhas, embora tenham sido detectados em nutridoras de idade semelhante, coletadas diretamente das colônias (ver Figs. 4 e 5). Este insucesso sugere 
que a manipulação das abelhas e o confinamento impedem a expressão deste gene, mas isto requer testes adicionais para melhor averiguar esta ocorrência.

\subsection{Expressão dos genes GSTs em tecidos de operárias tratadas com PPN}

PPN 2-[1-methyl-2-(4-phenoxyphenoxy)ethoxy]pyridine $\left(\mathrm{C}_{20} \mathrm{H}_{29} \mathrm{NO}_{3}\right)$ é um composto aromático, análogo de HJ (Hatakoshi et al., 1986; de Kort e Koopmanschap, 1991; Cusson et al., 1994) que mimetiza seu efeito. PPN é, principalmente, um regulador do crescimento do inseto e, dependendo da dose aplicada, impede a larva de atingir o estágio adulto e, portanto, impede a reprodução do inseto. Neste caso, funciona como um excelente pesticida. Em geral, mímicos de hormônio juvenil não são tóxicos para o inseto adulto, exceto quanto utilizados em altas doses (Meola et al., 1993). Assim, insetos adultos em geral sobrevivem a aplicações de PPN e a taxa de oviposição não é alterada, mas os ovos postos podem não se desenvolver. Ovos postos por Ctenocephalides felis (pulgas) tratadas com PPN frequentemente são desprovidos de vitelo, ou contém quantidades mínimas deste nutriente, e degeneram antes da formação da blastoderme (Palma et al., 1993). Contudo, a suscetibilidade de insetos adultos a PPN tem se mostrado bastante variável, dependendo da espécie de inseto e das condições de tratamento. A exposição de fêmeas adultas de espécies de Hemiptera, Coleoptera, Lepidoptera e Diptera a PPN tem como consequência a supressão da eclosão dos ovos (Hatakoshi, 1992; Ishaaya \& Horowitz, 1992; Bull \& Meola, 1994; Ishaaya et al., 1994; Mendel et al., 1994; Hattingh \& Tate, 1995; Higbee et al., 1995). Mas, Kookmanschap et al. (1989) observaram que PPN não tem efeito esterilizante no besouro Leptinotarsa decemlineata, exibindo fraca atividade ovicida. De modo similar, a atividade ovipositora do besouro Chilocorus nigritus não foi afetada por exposição de fêmeas adultas a PPN (Hattingh \& Tate, 1995). Efeitos óbvios de PPN sobre a produção e viabilidade de ovos também não foram observados após tratamento do besouro Circellium bacchus com PPN (Krüger \& Scholtz, 1997).

O LD50 de PPN para abelhas adultas é de mais de $100 \mu \mathrm{g} /$ abelha (WHO, 2001). Esta dosagem é muito maior que a recomendada para a utilização deste produto como inibidor de crescimento de insetos-pragas de lavouras, e neste contexto, PPN é considerado não-tóxico para as abelhas. De fato, PPN foi considerado praticamente inócuo quando fornecido no alimento a abelhas Bombus terrestris (de Wael et al., 1995). Mas ressalte-se que mesmo em concentrações muito mais baixas que a LD50, ou seja, aquela letal para 50\% da populaçãoteste, PPN pode causar efeitos fisiológicos bastante marcantes nas abelhas. Doses de 1,25, 2,5, 5 e $10 \mu \mathrm{g}$ de PPN inibiram de maneira dose-dependente o aumento da concentração de 
vitelogenina na hemolinfa de abelhas operárias durante a primeira semana de vida adulta (0-6 dias), assim como sua síntese pelo corpo gorduroso cultivado in vitro (Pinto et al., 2000). Vitelogenina é a principal proteína do vitelo dos ovos, e embora as abelhas operárias normalmente não se reproduzam, esta proteína é ativamente sintetizada, principalmente durante as duas primeiras semanas após a emergência, e tem outras funções fisiológicas. A vitelogenina tem participação fundamental em processos tão importantes quanto a transição das tarefas intra-nidais para extra-nidais (forrageamento), a longevidade, e a atividade secretora das glândulas hipofaríngeas para produção do alimento larval (Amdam et al., 2005; Seehuus et al., 2006; Amdam \& Omholt, 2003; Guidugli et al., 2005; Nelson et al., 2007).

No presente trabalho, doses de PPN equivalentes a 10 e $15 \mu \mathrm{g}$ foram topicamente aplicadas em abelhas operárias recém emergidas para a investigação do efeito sobre a expressão dos genes GSTs no sexto dia após aplicação. Os resultados mostraram consistente redução da expressão dos genes GSTs, estatisticamente significante para seis dos nove genes estudados, tanto no corpo gorduroso parietal (GSTS1, GSTS2, GSTD1, GSTO1, GSTZ1, GSTmic1) quanto na musculatura torácica (GSTS1, GSTS2, GSTD1, GSTO1, GSTT1, GSTmic1) .

Alguns trabalhos relatam que enzimas GSTs resistem à aplicação de inseticidas via aumento da biossíntese e, consequentemente, da atividade total (Enayati et al., 2005; Willoughby et al., 2006 e 2007), a qual pode ser decorrente de um aumento da taxa de transcrição dos respectivos genes. GSTs são capazes de metabolizar inseticidas por meio de desidrocloração redutora ou por reações com glutationa reduzida para produzir metabólitos hidrossolúveis mais facilmente excretáveis. Além disto, podem contribuir para a remoção de substâncias tóxicas produzidas pela ação de pesticidas. Porém, o que se observou em relação às GSTs de A. mellifera foi uma diminuição dos níveis de transcritos quando em presença de PPN. A expressão destes genes foi negativamente afetada, assim como a expressão de vitelogenina, acima mencionada (Pinto et al., 2000), sugerindo que nas abelhas adultas a ação de PPN prejudique a maquinaria de síntese de proteínas. Esta hipótese é consistente com a redução de vitelo nos ovos de diferentes espécies de insetos tratadas com PPN, e com a consequente supressão da eclosão, conforme descrito acima.

Portanto, as GSTs de A. mellifera aparentemente não agem na eliminação de PPN. No entanto, esta afirmação requer testes adicionais para verificação das atividades destas enzimas em resposta ao PPN. Não se pode ainda excluir um aumento de atividade enzimática em 
resposta a PPN, embora a redução dos níveis de transcritos tenha sugerido que não houve resposta à aplicação de PPN, pelo menos nas doses e condições aqui empregadas.

As enzimas GSTs têm sido relacionadas à resistência a inseticidas que nestes casos são utilizados como substratos e podem causar sua ativação. No entanto, em D. melanogaster foi constatado por meio de experimentos de microarrays que a resposta de indução de genes GSTs, P450s e de esterases por inseticida é mínima e foi sugerido que genes com função no metabolismo é que teriam a função de assegurar a sobrevivência do inseto sob efeito de inseticida (Willoughby et al., 2006).

Para verificar a possibilidade de ter ocorrido um aumento de expressão dos genes GSTs antes das 24 horas - tempo decorrido entre a aplicação tópica de PPN e a coleta das amostras de corpo gorduroso parietal e musculatura torácica para análise - foi investigado também a expressão de dois destes genes, GSTS2 e GSTmic1, nos tempos de 1, 6 e 11 horas após a aplicação. Com exceção de GSTmic1, que apresentou nível maior de transcritos no limite da significância estatística $(\mathrm{p}=0,048)$ na musculatura torácica de abelhas tratadas com PPN, no tempo de 1 hora, não houve indução de expressão.

Assim, nas condições experimentais definidas para este trabalho não houve indução da expressão de genes GSTs por PPN, ao contrário, a expressão foi reduzida após 24 horas de tratamento. Este resultado reforça a hipótese de que a ação de PPN nos insetos adultos induz alterações fisiológicas que redundam em redução da atividade gênica e da síntese de proteínas, inclusive daquelas enzimas com função de detoxificação, como as GSTs.

\subsection{Caracterização e expressão de possíveis ortólogos do gene codificador de} uma GST (HP19) de C. cephalonica em A. mellifera

Arif et al. (2004, 2008) descreveram uma GST em C. cephalonica, denominada HP19, à qual foi atribuída a função de regular a fosforilação do receptor de hexamerinas e, assim, participar do mecanismo de sequestro destas proteínas da hemolinfa pelo corpo gorduroso durante a metamorfose.

Mais especificamente, o modelo proposto por Arif et al. (2008) sugere que a proteína HP19 inibe a fosforilação do receptor de hexamerinas, e consequentemente sua atividade, no período em que as larvas dos insetos holometábolos estão se alimentando. A alimentação induz intensa síntese de hexamerinas no corpo gorduroso e simultânea secreção/estocagem na hemolinfa. No momento em que as larvas param de se alimentar em preparação para a metamorfose (muda metamórfica), os níveis de ecdisteróides aumentam e a proteína HP19 é 
inibida, permitindo assim que os receptores de hexamerinas sejam fosforilados e ativados (por uma tirosina quinase). O título de ecdisteróides então decai, as pré-pupas se transformam em pupas que se desenvolvem em adultos-faratos e as hexamerinas estocadas na hemolinfa são então paulatinamente sequestradas pelo corpo gorduroso. As pupas e adultos-faratos não se alimentam, mas usam o estoque de hexamerinas para obter os aminoácidos necessários para completar o seu desenvolvimento até o estágio adulto.

Em C. cephalonica, a proteína HP19 está presente na hemolinfa durante o estágio larval, mas não no estágio pupal e, isto é coerente com a função de bloquear o sequestro de hexamerinas em larvas. A ausência de expressão em pupas e adultos-faratos possibilitaria o sequestro de hexamerinas.

Assim, uma nova função foi descrita para um membro da classe das GSTs em insetos: participar de um aspecto fundamental da metamorfose, ou seja, a transição entre a estocagem de hexamerinas na hemolinfa larval e sua subsequente utilização no corpo gorduroso pupal e adulto-farato. Esta nova função descrita para uma GST motivou a busca de possíveis ortólogos do gene codificador da proteína HP19 no genoma de A. mellifera. Dos dez genes GSTs de A. mellifera apenas dois, GSTS1 e GSTS4, apresentaram similaridade (36\% e $35 \%$ ) com o gene codificador de HP19 de C. cephalonica e, em analogia, passaram a ser denominados $h p 19^{1}$ (GSTS1) e $h p 19^{2}$ (GSTS4). As isoenzimas citosólicas GST de humanos e roedores partilham mais de $40 \%$ de similaridade quando pertencem a uma mesma classe, valor próximo ao encontrado entre a HP19 de C. cephalonica e as proteínas deduzidas GSTS1 e GSTS4 de A. mellifera, porém, a similaridade entre classes é menor que 25\% (Hayes et al., 2005).

O sequenciamento das CDSs de $h p 19^{1}$ (GSTS1) e $h p 19^{2}$ (GSTS4) revelou diferenças estruturais e de organização dos íntrons e éxons destes genes. Estudos de expressão em diferentes estágios do desenvolvimento e tecidos de A. mellifera mostraram padrões distintos de expressão, sugerindo que as proteínas codificadas por estes genes desempenham papéis diferentes e específicos.

O gene $h p 19^{1}$ (GSTS1) é expresso no intestino e no corpo gorduroso visceral de larvas de operária em processo de tecelagem do casulo $\left(\mathrm{L}_{5} \mathrm{~S}\right)$. A expressão desaparece quando a muda metamórfica se aproxima para só reaparecerer dias após a muda metamórfica, em adultas-faratas intermediárias (fase Pbl) (ver Figs. 14 e 16). O perfil de expressão do gene hp191 (GSTS1) mostrou-se coerente com o modelo proposto por Arif et al. (2008), isto é, alta expressão em larvas e ausência de expressão em pupas e adultos-faratos iniciais. 
O gene $h p 19^{2}$ (GSTS4) tem um perfil de expressão diferente, isto é, relativamente baixa no corpo gorduroso visceral de larvas de $5^{\circ}$ instar em início da fase de tecelagem do casulo (fases $\mathrm{S}_{1}$ e $\mathrm{S}_{2}$ ), mas com nítido aumento ao final desta fase (fase $\mathrm{S}_{3}$ ). Nas fases subsequentes (pré-pupal, pupal e em adultas-faratas) a expressão é relativamente alta, mas com variações (ver Fig. 17). Este perfil de expressão se assemelha ao do gene codificador de uma GST (CfGSTs4) de Choristoneura fumiferana (Huang et al., 2008). No intestino, a expressão de $h p 19^{2}$ (GSTS4) é pouco abundante em larvas de $5^{\circ}$ instar em fase de tecelagem do casulo (fases $\mathrm{S}_{2}, \mathrm{~S}_{3}$ ), mas subsequentemente aumenta e assim permanece (ver Fig. 15). Este padrão de expressão é similar ao do gene CfGSTd5 que codifica uma GST do intestino médio de $C$. fumiferana (Huang et al., 2008). A expressão de $h p 19^{2}$ (GSTS4) no corpo gorduroso visceral e intestino de A. mellifera não condiz com o modelo de Arif et al. (2008), sugerindo que este gene não tem função na dinâmica de acúmulo e sequestro de hexamerinas durante a metamorfose.

O modelo de C. cephalonica aplicado a A. mellifera está representado na Fig. 25. 


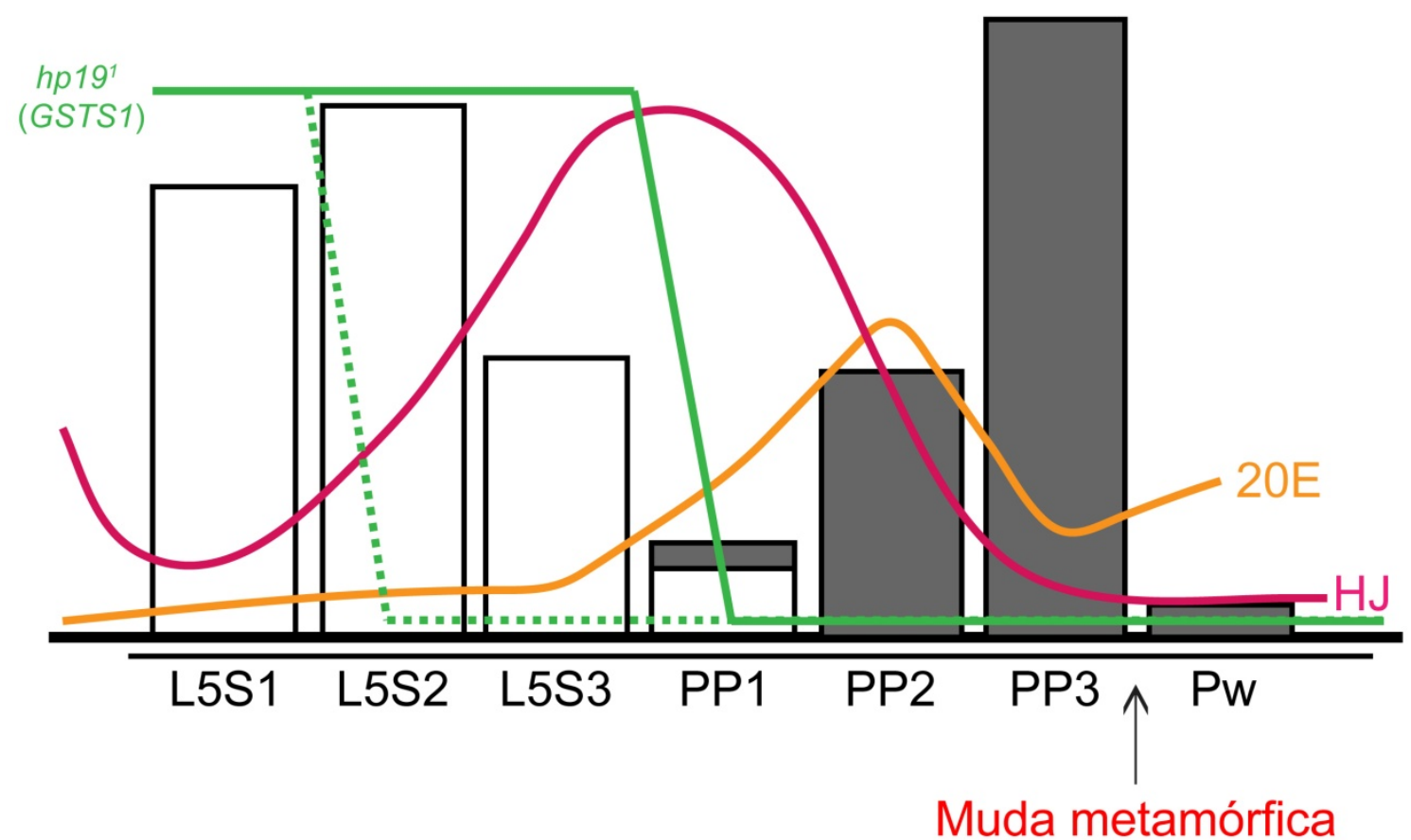

Figura 25 - Representação esquemática do modelo de Arif et al. (2008) e Burmester \& Scheller (1999) desenvolvido para C. cephalonica e aplicado a A. mellifera. O esquema representa a estocagem e sequestro de hexamerinas dependente da presença da putativa proteína ortóloga de HP19 de C. cephalonica em A. mellifera [aqui representada pelos níveis de transcritos $h p 19^{1}$ (GSTS1) no intestino posterior (linha verde cheia) e corpo gorduroso visceral (linha verde pontilhada)], e das concentrações de 20E e de $\mathrm{HJ}$ durante a muda metamórfica. $\mathrm{L}_{5} \mathrm{~S}_{1}, \mathrm{~L}_{5} \mathrm{~S}_{2}$ e $\mathrm{L}_{5} \mathrm{~S}_{3}$ : etapas sucessivas do $5^{\circ}$ instar larval, fase de tecelagem do casulo; $\mathrm{PP}_{1}, \mathrm{PP}_{2}, \mathrm{PP}_{3}$ : sucessivas fases de pré-pupa (pupa-farata); $\mathrm{Pw}$ - pupa. As curvas coloridas representam os títulos de HJ e 20E e dos transcritos de $h p 19^{1}$ (GSTS1) (linha verde). As colunas brancas indicam a concentração de hexamerinas estocadas na hemolinfa; as colunas em cor cinza representam o sequestro de hexamerinas pelas células do corpo gorduroso.

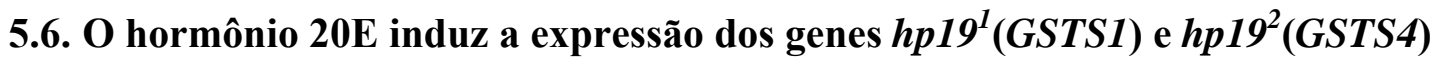

O modelo representado na Fig. 25 mostra que os níveis de transcritos $h p 19^{1}$ (GSTS1) são reduzidos à linha basal quando o título de ecdisteróides aumenta em preparação para a metamorfose. Para averiguar se este gene é regulado por ecdisteróides, larvas de operárias receberam $20 \mathrm{E}$ via oral, adicionado ao alimento larval contido nos favos. O tratamento oral com ecdisteróides foi efetivo em larvas de D. melanogaster (Meister \& Richards, 1996) e em larvas de A. mellifera, conforme foi possível constatar. Paralelamente, abelhas adultas-faratas (em fase Pp) também foram injetadas com 20E para verificação do efeito biológico, já que a injeção deste hormônio nesta fase do desenvolvimento resulta em atraso na pigmentação e esclerotização do exoesqueleto (Pinto et al., 1999; Santos et al., 2001). Este efeito na 
morfologia externa, facilmente observável, confirmou o efeito biológico de 20E (ver Fig. 20B).

$\mathrm{O}$ hormônio $20 \mathrm{E}$ foi fornecido às larvas de $5^{\circ}$ instar (em fase $\mathrm{F}_{1}$ ), as quais foram coletadas na fase, $F_{3}$ (ver Fig. 18A), para dissecção do intestino e verificação dos transcritos de $h p 19^{1}$ (GSTS1) e $h p 19^{2}$ (GSTS4). Na fase $\mathrm{F}_{3}$, o título endógeno de 20E é basal (Rachinsky et al., 1990). Esperava-se que a exposição ao ecdisteróide exógeno concorresse para inibir a transcrição de $h p 19^{1}$ (GSTS1), em concordância com o modelo proposto por Arif et al. (2008) em C. cephalonica (ver Fig. 25). No entanto, 20E induziu a atividade do gene $h p 19^{1}$ (GSTS1) no intestino larval (ver Fig. 18B) e o mesmo ocorreu no intestino das adultas-faratas injetadas com este hormônio (ver Fig. 20D). Resultado semelhante foi obtido por Feng et al. (1999, 2001) que mostraram em C. fumiferana indução de GSTs por ecdisteróides.

Os níveis de transcritos $h p 19^{2}$ (GSTS4) também foram averiguados nas larvas e adultas-faratas expostas a 20E. Nítido aumento do nível de expressão deste gene foi constatado nas larvas (ver Fig. 18), mas não nas adultas-faratas (ver Fig. 20C). Assim, a expressão do gene $h p 19^{2}$ (GSTS4) também é positivamente regulada por ecdisteróides, pelo menos nas larvas.

Em resumo, o perfil transcricional de $h p 19^{1}($ GSTS1) tanto no intestino posterior quanto no corpo gorduroso visceral (ver Figs. 14 e 16), torna este gene um candidato consistente a ortólogo do gene codificador da HP19 de C. cephalonica, com função na metamorfose. No entanto, diferente do esperado, e contrariando o modelo representado na Fig. 25, o gene $h p 19^{1}$ (GSTS1) é positivamente regulado por 20E. Este resultado supõe duas possibilidades: (1) ou o gene $h p 19^{1}$ (GSTS1) não é ortólogo do gene hp19 de C. cephalonica e, portanto, não tem função no esquema de regulação do sequestro de hexamerinas, ou (2) o gene $h p 19^{1}$ (GSTS1) é ortólogo de $h p 19$ de C. cephalonica, tem função no esquema de regulação do sequestro de hexamerinas, mas este esquema não se processa do mesmo modo que em C. cephalonica.

\subsection{O HJ induz a expressão de $h p 19^{1}$ (GSTS1), mas não de $h p 19^{2}$ (GSTS4)}

Outro hormônio importante no processo de metamorfose é o HJ que em sinergia com $20 \mathrm{E}$ garante a muda de um instar larval para o seguinte e, quando seu título decai, e em presença de 20E, a larva se transforma em pupa (Riddiford et al., 2003).

No modelo representado na Fig. 25 pode-se constatar a relação oposta entre os níveis de HJ e de transcritos $h p 19^{1}$ (GSTS1). Esta relação nos levou a hipotetizar que o hormônio 
regula negativamente a expressão deste gene, o que reforçaria possível papel na metamorfose de A. mellifera. Com a finalidade de verificar se $h p 19^{1}$ (GSTS1) é suscetível à ação de HJ foi procedida à aplicação tópica deste hormônio em larvas de $5^{\circ}$ instar em fase de alimentação $\left(\mathrm{L}_{5} \mathrm{~F}\right)$ e os níveis de transcritos foram verificados 24 horas depois, na fase seguinte, $\mathrm{L}_{5} \mathrm{~S}$, de tecelagem do casulo (ver Fig. 19A). Paralelamente, adultas-faratas iniciais receberam aplicação tópica de PPN para verificação do efeito biológico, o qual foi confirmado pela aceleração dos processos de pigmentação e esclerotização do exoesqueleto (ver Fig. 21B) referidos na literatura (Bitondi et al., 1998; Zufelato et al., 2000). Embora estruturalmente distinto, PPN mimetiza a ação do HJ, com a vantagem de ser metabolicamente mais estável, tendo assim, uma ação mais duradoura (Hatakoshi et al., 1986; de Kort \& Koopmanschap, 1991; Cusson et al., 1994).

HJ e o análogo PPN induziram o aumento da abundância de transcritos de hp19 ${ }^{1}$ (GSTS1) tanto no intestino larval quanto no de adultas-faratas (ver Figs. 19B e 21C). Resultado similar foi obtido por Wu \& Lu (2008) em S. litura. Neste Lepidoptera, a expressão do gene que codifica uma proteína GST no corpo gorduroso foi induzida por HJ. Por outro lado, considerando que as GSTs podem se ligar a compostos lipofílicos (Hayes \& Pulford, 1995), e estão envolvidas no transporte de uma variedade de hormônios e metabólitos (Maruyama \& Listowsky, 1984; Listowsky et al., 1988; Ishigaki, 1989), elas poderiam similarmente atuar como ligadoras do terpenóide $\mathrm{HJ}$ e assim, regular sua atividade.

Os níveis de transcritos de $h p 19^{2}$ (GSTS4) também foram avaliados nas larvas e adultas-faratas expostas a HJ e PPN, sem que fossem constatadas modificações em comparação com os controles, não tratados (ver Figs. 19B e 21C). Portanto, deduz-se que nem todos os genes codificadores de GSTs são regulados por HJ.

A nítida ação indutora da expressão de $h p 19^{1}($ GSTS1) aqui estabelecida tanto para o HJ quanto para 20E sugere que este gene é importante no contexto da muda metamórfica, coordenada por ambos os hormônios. Mas estamos longe ainda de saber a função deste gene neste evento do desenvolvimento de A. mellifera.

\subsection{O silenciamento gênico pós-transcricional de $h p 19^{1}$ (GSTS1) causa redução do} teor de hexamerina HEX 70a na hemolinfa

Experimentos visando o silenciamento do gene $h p 19^{1}$ (GSTS1) foram realizados com o objetivo de investigar sua possível função na dinâmica de sequestro de hexamerinas. Larvas 
foram então alimentadas com dsRNA para silenciamento pós-transcricional deste gene. A consequente diminuição dos níveis de transcritos causou concomitante redução dos níveis da hexamerina HEX 70a na hemolinfa larval. Dessa forma, pode-se sugerir que, assim como ocorre com a HP19 de C. cephalonica (Arif et al., 2008), o produto do ortólogo putativo em A. mellifera, $h p 19^{1}$ (GSTS1), está envolvido no bloqueio da ativação do receptor de hexamerinas. O knockdown deste gene e, consequentemente, da síntese da respectiva proteína, permitiria a ativação do receptor e o sequestro de hexamerinas da hemolinfa pelo corpo gorduroso, levando à diminuição dos níveis desta proteína na hemolinfa. O resultado obtido (ver Fig. 23) é consistente com esta hipótese.

O silenciamento gênico foi temporário e os níveis de transcritos foram recuperados quando as larvas que sobreviveram ao tratamento com dsRNA se desenvolveram em adultasfaratas e atingiram a fase Pbl. Foi surpreendente observar que, nesta fase, os níveis de transcritos $h p 19^{1}$ (GSTS1) mostraram-se mais elevados em alguns adultos-faratos alimentados no estágio larval com dsRNA que nos controles. Estudos em mamíferos mostram que dsRNAs podem eventualmente agir como ativadores da transcrição, ou seja, de modo contrário ao esperado. Aparentemente, estes dsRNAs se ligam a alvos na região promotora de genes e assim ativariam sua expressão (Li et al., 2006; Huang et al., 2010). 
CONCLUSÕES 


\section{CONCLUSÕES}

1. O sequenciamento total ou parcial dos cDNAs dos dez genes aqui estudados revelou domínios altamente conservados, mas também, diferenças estruturais e de organização de íntrons e éxons. As proteínas deduzidas destas sequências gênicas apresentam domínios típicos de glutationa S-transferases (GSTs) citosólicas e microssomais, confirmando que estes genes codificam estas classes de enzimas;

2. A análise da expressão dos genes GSTs no corpo gorduroso parietal e na musculatura torácica de abelhas operárias adultas revelou, em geral, maior densidade de transcritos nas forrageiras que nas nutridoras. Este resultado sugere que o aumento da atividade destes genes está relacionado à proteção do organismo frente ao estresse oxidativo resultante do envelhecimento e do metabolismo aeróbico requerido para as intensas atividades de forrageamento;

3. Em geral, operárias adultas alimentadas com geléia real e beebread (ricos em proteínas, lipídios, carboidratos, vitaminas, sais minerais, etc) mostraram maior densidade de transcritos GSTs (no corpo gorduroso parietal e na musculatura torácica) que as alimentadas exclusivamente com xarope (solução de açúcar). Este resultado sugere que a dieta mais calórica induz a expressão dos genes GSTs (e a síntese das respectivas enzimas) possivelmente para inativação do excesso de ROS que gera estresse oxidativo;

4. Houve redução da expressão dos genes GSTs no corpo gorduroso parietal e na musculatura torácica de abelhas operárias adultas expostas a PPN, um análogo de HJ, que pode atuar como inseticida (xenobiótico) em insetos adultos. Portanto, ao contrário do esperado, as abelhas adultas não resistem à aplicação deste xenobiótico por meio do aumento da atividade dos genes GSTs;

5. Os produtos de dois dos genes GSTs de A. mellifera (GSTS1 e GSTS4) apresentaram similaridade de 35 e 36\%, respectivamente, com a proteína HP19 de C. cephalonica, cuja inibição tem sido relacionada ao aumento de $20 \mathrm{E}$ e iniciação do sequestro de hexamerinas durante a metamorfose. Estes dois genes da abelha foram então denominados $h p 19^{1}$ (GSTS1) e $h p 19^{2}$ (GSTS4) e os perfis de expressão de ambos foram caracterizados tanto no intestino 
posterior quanto no corpo gorduroso visceral. O perfil de expressão de $h p 19^{1}$ (GSTS1), mas não o perfil de expressão de $h p 19^{2}$ (GSTS4), condiz com função análoga à do gene $h p 19$ de $C$. cephalonica na metamorfose. No entanto, os experimentos in vivo de manipulação dos títulos de hormônios da metamorfose (20E e HJ) mostraram efeito oposto ao esperado, ou seja, estes hormônios induziram a expressão de $h p 19^{1}$ (GSTS1). Em conjunto, estes resultados sugerem duas possibilidades alternativas: primeira, que o gene $h p 19^{1}$ (GSTS1) não é ortólogo do gene hp19 de C. cephalonica e, portanto, não tem função na via de regulação do sequestro de hexamerinas ou, segunda, que o gene $h p 19^{1}$ (GSTS1) é ortólogo de hp19 de C. cephalonica, tem função na regulação do sequestro de hexamerinas, mas esta regulação não se processa do mesmo modo que em C. cephalonica;

6. O silenciamento de $h p 19^{1}$ (GSTS1) (o provável ortólogo do gene hp19 de C. cephalonica) resultou em diminuição dos níveis da hexamerina HEX 70a na hemolinfa. Este resultado condiz com a hipótese de que a inibição do produto de $h p 19^{1}$ (GSTS1) permite a ativação do receptor específico e o sequestro de hexamerinas pelo corpo gorduroso, além de reforçar a segunda possibilidade mencionada ao final do parágrafo anterior. 


\section{REFERÊNCIAS BIBLIOGRÁFICAS}

AMDAM, G. V.; OMHOLT, S. W. 2003. The hive bee to forager transition in honey bee colonies: the Double repressor hypothesis. J. Theor. Biol. 223, 451-464.

AMDAM, G. V.; AASE, A. L.; SEEHUUS, S. C.; FONDRK, M. K.; NORBERG, K.; HARTFELDER, K. 2005. Social reversal of immunosenescence in honey bee workers. Exp. Gerontol. 40, 939-947.

AMENT, S. A.; CORONA, M.; POLlOCK, H. S.; ROBINSON, G. E. 2008. Insulin signaling is involved in the regulation of worker division of labor in honey bee colonies. Proc. Nat. Acad. Sci. USA. 105, 4226-4231.

ARIF, A.; SCHELlER, K.; DUTTA-GUPTA, A. 2003. Tyrosine kinase mediated phosphorylation of the hexamerin receptor in the rice moth Corcyra cephalonica by ecdysteroids. Insect Biochem. Mol. Biol. 33, 921-928.

ARIF, A.; VASANTHI, P.; HANSEN, I. A.; SCHELlER, K.; DUTTA-GUPTA, A. 2004. The insect haemolymph protein HP19 mediates the nongenomic effect of ecdysteroids on acid phosphatase activity. J. Biol. Chem. 279, 28000-28008.

ARIF, A.; MANOHAR, D.; GULLIPALLI, D.; DUTTA-GUPTA, A. 2008. Regulation of hexamerin receptor phosphorylation by hemolimph protein HP19 and 20hydroxyecdysone directs hexamerin uptake in the rice moth Corcyra cephalonica. Insect Biochem. Mol. Biol. 38, 307-319.

BITONDI, M. M. G.; MORA, I. M.; SIMÕES, Z. L. P.; FIGUEIREDO, V. L. C. 1998. The Apis mellifera pupal melanization program is affected by treatment with a juvenile hormone analogue. J. Insect Physiol. 44, 499-507.

BRADFORD, M. M. 1976. A rapid and sensitive method for the quantification of microgram quantities of protein utilizing the principle of protein-dye binding. Anal. Biochem. 72, $248-254$. 
BRUCE-KELlER, A. J.; WHITE, C. L.; GUPTA, S.; KNIGHT, A. G.; PISTELL, P. J.; INGRAM, D. K.; MORRISON, C. D., KELLER, J. N. 2010. NOX activity in brain aging: Exacerbation by high fat diet. Free radical Biol. \& Medic. 49, 22-30.

BULL, D. L.; MEOLA, R. W. 1994. Efficacy and toxico-dynamics of pyriproxyfen after treatment of insecticide susceptible and resistant strains of the house fly (Diptera: Muscidae). J. Econ. Entomol. 87, 1407-1415.

BURMESTER, T.; SCHELLER, K. 1992. Identification of binding proteins involved in the stagespecific uptake of arylphorin by the fat body cells of Calliphora vicina. Insect Biochem. Mol. Biol. 22, 211-220.

BURMESTER, T.; SCHELLER, K. 1997. Developmentally controlled cleavage of the Calliphora arylphorin receptor and post-translational action of the steroid hormone 20hydroxyecdysone. Eur. J. Biochem. 247, 695-702.

BURMESTER, T.; SCHELLER, K. 1999. Ligands and receptors: common theme in insect storage protein transport. Naturwissenschaften 86, 468-474.

CAVUSOGLU, K.; YAPAR, K.; YALÇIN, E. 2009. Royal jelly (Honey Bee) is a potential antioxidant against cadmium-induced genotoxicity and oxidative stress in albino mice. J. Med. Food. 12, 1286-1292.

CHELVANAYAGAM, G.; PARKER, M. W.; BOARD, P. G. 2001. Fly fishing for GSTs: a unified nomenclature for mammalian and insect glutathione transferases. Chem. Biol. Interact. 133, 256-260.

CHUNG, S. O.; KUBO, T.; NATORI, S. 1995. Molecular cloning and sequencing of arylphorin binding protein in protein granules of the Sarcophaga fat body. J. Biol. Chem. $270,4624-4631$.

CLARK, A. G. 1989. The comparative enzymology of the glutathione-S-transferases from non-vertebrate organisms. Comp. Biochem. Physiol. 92B, 419-446. 
CLAUDIANOS, C.; RANSON, H.; JOHSON, R. M.; BISWAS, S.; SCHULER, M. A.; BERENBAUM, M. R.; FEYEREISEN, R.; OAKESHOTT, J. G. 2006. A deficit of detoxification enzymes: pesticide sensitivity and environmental response in the honeybee. Insect Mol. Biol. 15, 615-636.

COCHRANE, B. J.; MORRISSEY, J.; LEBLANC, G. 1987. The genetics of xenobiotic metabolism and Drosophila - IV Purification and characterization of the major glutathione-S-transferase. Insect Biochem. 17, 731-738.

COHEN, E. 1987. Purification of glutathione-S-transferase from the flour beetle Tribolium castaneun. Comp. Biochem. Physiol. B. 88, 675-679.

CORONA, M.; HUGHES, K. A.; WEAVER, D. B.; ROBINSON, G. E. 2005. Gene expression patterns associated with queen honey bee longevity. Mech. Ageing Devel. $126,1230-1238$.

CORONA, M.; ROBINSON, G. E. 2006. Genes of the antioxidant system of the honey bee: annotation and phylogeny. Insect Mol. Biol. 15, 687-701.

CUSSON, M.; YU, C. G.; CARRUTHERS, K.; WYATT, G. R.; TOBE, S. S.; MCNEIL, J. N. 1994. Regulation of vitellogenin production in armyworm moths, Pseudaletia unipuncta. J. Insect Physiol. 40, 129-136.

DAVIS, M.; O’KEEFE, S. L.; PRIMROSE, D. A.; HODGETTS, R. B. 2007. A neuropeptide hormone cascade controls the precise onset of post-eclosion cuticular tanning in Drosophila melanogaster. Development. 134, 4395-4404.

DE KORT, C. A.; KOOPMANSCHAP, A. B. 1991. A juvenile hormone analogue affects the protein pattern of the haemolymph in last-instar larvae of Locusta migratoria. J. Insect Physiol. 37, 87-93. 
DE WAEL, L.; DE GREEF, M.; VAN LAERE, O. 1995. Toxicity of Pyriproxyfen and Fenoxycarb to Bumble Bee Brood using a new Method for Testing Insect Growth Regulators, J. Agric. Res. 34, 3-8.

DE WILDE, J.; BEETSMA, J. 1982. The physiology of caste development in social insects. Adv. Insect Physiol. 16, 167-256.

DING, Y. C.; ORTELLI, F.; ROSSITER, L. C.; HEMINGWAY, J.; RANSON, H. 2003. The Anopheles gambiae glutathione transferase super gene family: annotation, phylogeny and expression profiles. Bmc. Genomics. 4, 35.

DUHAMEL, R. C.; KUNKEL, J. G. 1987. Molting-cycle regulation of hemolimph protein claerence in cockroaches: possible size-dependent mechanism. J. Insect Physiol. 33, 155158.

DUTTA-GUPTA, A.; ASHOKs, M. 1998. A comparative study on the ecdysteroid titer in the normal, decapitated and thorax-ligated larvae of stem borer, Chilo partellus and rice moth, Corcyra cephalonica. Entomon. 23, 245-250.

EDWARDS, R.; DIXON, D. P.; WALBOT, V. 2000. Plant glutathione-S-transferases: enzymes with multiple functions in sickness and in health. Trends Plant. Sci. 5, 193-198.

ENAYATI, A. A.; RANSON, H.; HEMINGWAY, J. 2005. Insect glutathione tranferases and insecticide resistance. Insect Mol. Biol. 14, 3-8.

FELDLAUFER, M. F.; HERBERT, Jr. E. W.; SVOBODA, J. A.; THOMPSON, M. J.; LUSBY, W. R. 1985. Makisterone A: The major ecdysteroid from pupa of the honeybee, Apis mellifera. Insect Biochem. 15, 597-600.

FENG, Q. L.; DAVEY, K. G.; PANG, A. S. D.; PRIMAVERA, M.; LADD, T. R.; ZHENG, S. C.; SOHI, S. S.; RETNAKARAN, A.; PALLI, S. R. 1999. Glutatione-S-transferase from the spruce budworm, Choristoneura fumiferana: identification, characterization, localization, cDNA cloning and expression. Insect Biochem. Mol. Biol. 29, 779-793. 
FENG, Q. L.; DAVEY, K. G.; PANG, A. S. D.; LADD, T. R.; RETNAKARAN, A.; TOMKINS, B. L.; ZHENG, S.; PALLI, S. R. 2001. Developmental expression and stress induction of glutathione S-transferase in the spruce budworm, Choristoneura fumiferana. J. Insect Physiol. 47, 1-10.

FINKEL, T.; HOLBROOK, N. J. 2000. Oxidants, oxidative stress and the biology of ageing. Nature 408, 239-247.

FLURI, P.; LÜSCHER, M.; WILLE, H.; GERIG, L. 1982. Changes in the weight of the pharyngeal gland and hemolymph titers of juvenile hormone, protein and vitellogenin in worker honey bees. J. Insect Physiol. 28, 61-68.

FRANCIOSA, H.; BERGE, J. B. 1995. Glutathione-S-transferases in housefly (Musca domestica): location of GST-1 and GST-2 families. Insect Biochem. Mol. Biol. 25, 311317.

GILBERT, L. I.; GRANGER, N. A.; ROE, R. M. 2000. The juvenile hormones: historical facts and speculations on future research directions. Insect Biochem. Mol. Biol. 30, 617644.

GILBERT, S. F. 2006. Developmental Biology. 8.ed. Sinauer Associates Inc., U.S.A.

GRANT, D. F.; MATSUMURA, F. 1988. Glutathione-S-transferase-1 in Aedes aegypti larvae: Purification and properties. Insect Biochem. 18, 615-622.

GUIDUGLI, K. R.; NASCIMENTO, A. M.; AMDAM, G. V.; BARCHUK, A. R.; OMHOLT, S.; SIMÕES, Z. L. P.; HARTFELDER, K. 2005. Vitellogenin regulates hormonal dynamics in the worker caste of a eusocial insect. FEBS Letters. 579, 4961-4965.

GUO, H.; KOUZUMA, Y.; YONEKURA, M. 2009. Strutures and properties of antioxidative peptides derived from Royal jelly protein. Food Chem. 113, 238-245. 
HARMAN, D. 1956. Aging - a theory based on free-radical and radiation chemistry. J. Gerontol. 11, 298-300.

HATAKOSHI, M.; AGUI, N.; NAKAYAMA, I. 1986. 2-[1-methyl-2-(4-phenoxyphenoxy) ethoxyl] pyridine as a new insect juvenile hormone analogue: induction of supernumerary larvae in Spodoptera litura (Lepidoptera: Noctuidae). Appl. Entomol. Zool. 21, 351-353.

HATAKOSHI, M. 1992. An inhibitory mechanism over oviposition in the tobacco cutworm, Spodoptera litura by juvenile hormone analogue pyriproxyfen. J. Insect Physiol. 38, 793-801.

HATTINGH, V.; TATE, B. 1995. Effects of field-weather residues of insect growth regulators on some Coccinellidae (Coleoptera) of economic importance as biocontrol agents. Bull. Entomol. Res. 85, 489-93.

HAUNERLAND, N. H. 1996. Insect storage proteins: gene families and receptors. Insect Biochem. Mol. Biol. 26, 755-765.

HAYES, J. D.; PULFORD, D. J. 1995. The glutathione-S-transferase supergene family: regulation of GST and the contribution of the isoenzymes to cancer chemoprotection and drug resistance. Crit. Rev. Biochem. Mol. Biol. 30, 445-600.

HAYES, J. D.; FLANAGAN, J. U.; JOWSEY, I. R. 2005. Glutathione transferases. Annu. Rev. Pharmacol. Toxicol. 45, 51-88.

HIGBEE, B. S.; HORTON, D. R.; KRYSAN, J. L. 1995. Reduction of egg hatch in pear psylla (Homoptera, Psyllidae) after contact by adults with insect growths regulators. J. Econ. Entomol. 88, 1420-1424.

HUANG, Z. Y.; ROBINSON, G. E.; TOBE, S. S.; YAGI, K. J.; STRAMBI, C.; STRAMBI, A.; STAY, B. 1991. Hormonal regulation of behavioral development in the honey bee is based on changes in the rate of juvenile hormone biosynthesis. J. Insect Physiol. 37, 733741. 
HUANG, Y.; KRELL, P. J.; LADD, T.; FENG, Q.; ZHENG, S. 2008. Cloning, characterization and expression of two glutathione-S-transferase cDNAs in the spruce budworm, Choristoneura fumiferana. Arch. Insect Biochem. Physiol. 70, 44-56.

HUANG, V.; QUIN, Y.; WANG, J.; WANG, X.; PLACE, R. F.; LIN, G.; LUE, T. F.; LI, L. C. 2010. RNAa is conserved in mammalian cells. Plos One. 5, e8848.

HUBER P. C.; ALMEIDA W. P.; FÁTIMA A. 2008. Glutationa e enzimas relacionadas: papel biológico e importância em processos patológicos. Nova Química 31, 1170-1179.

ISHAAYA, I.; HOROWITZ, A. R. 1992. Novel phenoxy juvenile hormone analog (pyriproxyfen) suppresses embryogenesis and adult emergence of sweetpotato whitefly (Homoptera: Aleyrodidae). J. Econ. Entomol. 85, 2113-2117.

ISHAAYA, I.; DE COCK, A.; DEGHEELE, D. 1994. Pyriproxyfen, a potent suppressor of egg hatch and adult formation of the greenhouse whitefly (Homoptera: Aleyrodidae). J. Econ. Entomol. 87, 1185-9.

ISHIGAKI, S.; ABRAMOVITZ, M.; LISTOWSKY, I. 1989. Glutathione-S-transferases are major cytosolic thyroid hormone binding proteins. Arch. Biochem. Biophys. 273, 265272.

JASSIM, O.; HUANG, Z. Y.; ROBINSON, G. E. 2000. Juvenile hormone profiles of worker honey bees, Apis mellifera, during normal and accelerated behavioral development. J. Insect Physiol. 46, 243-249.

KELLER, L.; JEMIELITY, S. 2006. Social insects as a model to study the molecular basis of ageing. Exper. Geron. 41, 553-556.

KETTERER, B.; MEYER, D.; CLARK, A. G. 1989. In: SIES H.; KETTERER B. (eds) Glutathione Transferases. Elsevier, North Holland. 
KIRANKUMAR, N.; ISMAIL, S. M.; DUTTA-GUPTA, A. 1997. Uptake of storage protein in the rice moth Cocyra cephalonica: identification of storage protein binding proteins in the fat body cell. Insect Biochem. Mol. Biol. 27, 671-679.

KOOKMANSCHAP, A. B.; OOUCHI, H.; DE KORT, C. A. D. 1989. Effects of a juvenile hormone analogue on the eggs, post- embryonic development, metamorphosis and diapause induction of the Colorado potato beetle, Leptinotarsa decemlineata. Entomol. Exp. Appl. 50, 255-63.

KRÜGER, K.; SCHOLTZ, C. H. 1997. Possible risk posed by drift of the insect growth regulator pyriproxyfen to the rare dung beetle Circellium bacchus (F.) in a national park. J. Insect Conserv. 1, 215-220.

LAEMMLI, U. K. 1970. Cleavage of structural proteins during the assembly of the head of bacteriophage T4. Nature. 227, 680-685.

LAIDLAW, H. H. 1992. The hive and the honey bee. Ed. Graham, J. M. Dadant, Hamilton 276-271.

LE CONTE, Y.; HEFETZ, A. 2008. Primer pheromones in social hymenoptera. Annu. Rev. Entomol. 53, 523-542.

LEVENBOOK, L.; BAUER, A. C. 1984. The fate of the larval storage protein calliphorin during adult development of Calliphora vicina. Insect Biochem. 14, 77-86.

LI, L. C.; OKINO, S. T.; ZHAO, H.; POOKOT, D.; PLACE, R. F.; URAKAMI, S.; ENOKIDA, H.; DAHIYA, R. 2006. Small dsRNAs induce transcriptional activation in human cells. Proc. Natl. Acad. Sci. USA. 103, 17337-17342.

LISTOWSKY, I.; ABRAMOVITZ, M.; HOMMA, H.; NIITSU, Y. 1988. Intracellular binding and transport of hormones and xenobiotics by glutathione-S-transferases. Drug Metab. Rev. 19, 305-318. 
LOCKE, M.; COLLINS, J. V. 1965. The structure and formation of protein granules in the fat body of an insect. J. Cell Biol. 26, 857-884.

LOCKE, M.; COLliNS, J. V. 1966. Sequestration of protein by the fat body of an insect. Nature 210, 552-553.

LOCKE, M.; COLLINS, J. V. 1967. Protein uptake in multi vesicular bodies in the moltintermolt cycle of an insect. Science 158, 467-469.

LOCKE, M.; COLLINS, J. V. 1968. Protein uptake into multivesicular bodies and storage granules in the fat body of an insect. J. Cell Biol. 36, 153-183.

LOURENÇO, A. P.; MACKERT, A.; CRISTINO, A. S.; SIMÕES, Z. L. P. 2008. Validation of reference genes for gene expression studies in the honey bee, Apis mellifera, by quantitative real-time. Apidologie 39, 372-385.

MANNERVIK, B.; AWASTHI, Y. C.; BOARD, P. G.; HAYES, J. D.; DI-LLIO, C.; KETTER, B.; LISTOWSKY, I.; MORGENSTERN, R.; MURAMATSU, M.; PEARSON, W. R.; PICKETT, C. B.; SATO, K.; WIDERSTEN M.; WOLF, C. R. 1992. Nomenclature for human glutathione transferase. Biochem. J. 282, 305-306.

MARTINS, J. R.; NUNES, F. M.; SIMÕES, Z. L.; BITONDI, M. M. 2008. A honeybee storage protein gene, hex 70a, expressed in developing gonads and nutritionally regulated in adult fat body. J. Insect Physiol. 54, 867-877.

MARUYAMA, H.; LISTOWSKY, I. 1984. Preferential binding of steroids by anionic forms of rat glutathione-S-transferase. J. Biol. Chem. 259, 12449-12455.

MEISTER, M.; RICHARDS, G. 1996. Ecdysone and insect immunity: the maturation of the inducibility of the Diptericin gene in Drosophila larvae. Insect Biochem. Mol. Biol. 26, $155-160$. 
MENDEL, Z.; BLUMENBERG, D.; ISHAAYA, I. 1994. Effects of some insect growth regulators on natural enemies of scale insects (Hom.: Coccoidea). Entomophaga. 39, 199-209.

MEOLA, R.; READY, S.; MEOLA, S. 1993. In: WILDEY, K. B.; ROBINSON, W. H. Physiological effects of the juvenoid pyriproxyfen on adults, eggs, and larvae of the cat flea. Proceedings of the First International Conference on Insect Pests in the Urban Environment. 221-228.

MICHELETTE, E. R.; SOARES, A. E. E. 1993. Characterization of preimaginal developmental stages in Africanized honey bee workers (Apis mellifera L). Apidologie $24,431-440$.

MICHENER, C. D. 1969. Comparative social behavior of bees. Ann. Review Entomol. 14, 299-342.

MICHENER, C. D. 1974. The social behavior of the bees: a comparative study. Cambridge, Mass. Harvard Univ. Press, Londres.

MOTOYAMA, N.; DAUTERMAN, W. C. 1977. Purification and properties of house fly glutathione-S-transferase. Pestic. Biochem. Physiol. 7, 361-369.

MOTOYAMA, N.; DAUTERMAN, W.C. 1978. Molecular weight, subunit and multiple forms of glutathione-S-transferase from the houses flies. Insect Biochem. 8, 337-348.

NAGAI, T.; SAKAI, M.; INOUE, R.; INOUE, H.; SUZUKI, N. 2001. Antioxidative activities of some commercially honeys, royal jelly, and propolis. Food Chem. 75, 237-240.

NELSON, C. M.; IHLE, K. E.; FONDRK, M. K.; PAGE, R. E.; AMDAM, G. V. 2007. The gene vitellogenin has multiple coordinating effects on social organization. PLoS Biol. 5, 673-677.

NIJHOUT, H. F.; WHEELER, D. E. 1982. Juvenile hormone and physiological basis of insect polymorphism. Q. Rev. Biol. 57, 109-133. 
PAGE, R. E.; PENG, Y. S. 2001. Aging in development in social insects with emphasis on the honey bee, Apis mellifera L. Exp. Gerontol. 36, 695-711.

PAGE, R. E. J.; ERBER, J. 2002. Levels of behavioral organization and the evolution of division of labor. Naturwissenschaften 89, 91-106.

PALMA K. G.; MEOLA S. M.; MEOLA R. W. 1993. Mode of action of pyriproxyfen and methoprene on eggs of Ctenocephalides felis (Siphonaptera: Pulicidae). J. Med. Entomol. $30,421-426$.

PARKER, J. D.; PARKER, K. M.; SOHAL, B. H.; SOHAL, R. S.; KELlER, L. 2004. Decreased expression of $\mathrm{Cu}-\mathrm{Zn}$ Superoxide Dismutase 1 in ants with extreme life-span. Proc. Nat. Acad. Sci. USA. 101, 3486-3489.

PEIREN, N.; GRAAF, D. C.; VANROBAEYS, F.; DANNEELS, E. L.; DEVREESE, B.; BEEUMEN, J. V.; JACOBS, F. J. 2008. Proteomic analysis of the honey bee worker venom gland focusing on the mechanisms of protection against tissue damage. Toxicon. $52,72-83$.

PEREZ-CAMPO, R..; LOPEZ-TORRES, M.; CADENAS, E.; ROJAS, C.; BARJA, G.; 1998. The rate of free radical production as a determinant of the rate of aging: evidence from the comparative approach. J. Comp. Physiol. B. 168, 149-158.

PICKETT, C. B.; LU, A. Y. H. 1989. Glutathione-S-transferases: gene structure, regulation and biological function. Ann. Rev. Biochem. 58, 743-764.

PINTO, L. Z.; BITONDI, M. M. G.; SIMÕES, Z. L. P. 1999. Inhibition of vitellogenin synthesis in Apis mellifera workers by a juvenile hormone analogue, pyriproxyfen. J. Insect. Physiol. 46, 153-160.

PINTO L. Z.; BITONDI M. M.; SIMÕES Z. L. 2000. Inhibition of vitellogenin synthesis in Apis mellifera workers by a juvenile hormone analogue, pyriproxyfen. J. Insect Physiol. 46, 153-160. 
RACHINSKY, A.; STRAMBI, C.; STRAMBI, A.; HARTFELDER, K. 1990. Caste and metamorphosis: hemolimph titers of juvenile hormone and ecdysteroids in last instar honey bee larvae. Gen. Comp. Endocrinol. 79, 31-38.

RANSON, H.; CLAUDIANOS, C.; ORTELli, F.; ABGRALL, C.; HEMINGWAY, J.; SHARAKHOVA, M. V.; et al. 2002. Evolution of supergene families associated with insecticide resistance. Science 298, 179-181.

REMBOLD, H. 1987. Caste specific modulation of juvenile hormone titers in Apis mellifera. Insect Biochem. 17, 1003-1006.

REMBOLD, H. 1987b. Caste differentiation of the honey bee - fourteen years of biochemical research at Martinsried. In: EDER, J. REMBOLD, H. (Eds.), Chemistry and Biology of Social Insects, Peperny, München.

RIDDIFORD, L. M.; HIRUMA, K.; ZHOU, X.; NELSON, C. A. 2003. Insights into the molecular basis of the hormonal control of molting and metamorphosis from Manduca sexta and Drosophila melanogaster. Insect Biochem. Mol. Biol. 33, 1327-1338.

ROBINSON, G. E.; STRAMBI, C.; STRAMBI, A.; FELDLAUFER, M. F. 1991. Comparison of juvenile hormone and ecdysteroid titers in adult worker and queen honey bees (Apis mellifera). J. Insect Physiol. 37, 929-935.

RUTHERFORD, K.; PARKHILL, J.; CROOK, J.; HORSNELL, T.; RICE, P.; RAJANDREAM, M. A.; BARRELL, B. 2000. Artemis: sequence visualization and annotation. Bioinformatics 16, 944-945.

SANTOS, A. E.; BITONDI, M. M. G.; SIMÕES, Z. L. P. 2001. Hormone-dependent protein patterns in integument and cuticular pigmentation in Apis mellifera during pharate adult development. J. Insect Physiol. 47, 1275-1282. 
SAWICKI, R.; SINGH, S. P.; MONDAL, A. K.; BENES, H.; ZIMNIAK, P. 2003. Cloning, expression and biochemical characterization of one Epsilon-class (GST-3) and ten deltaclass (GST-1) glutathione-S-transferases from Drosophila melanogaster, and identification of additional nine members of the Epsilon class. Biochem. J. 370, 661-669.

SCHELLER K.; FISHER B.; SCHENKEL H. 1990. Molecular properties, functions and developmentally regulated biosynthesis of arylphorin in Calliphora vicina. In: HAGERDORN, H. H.; HILDEBRAND, J. G.; KIDWELL, M. G.; LAW, J. H.; (Eds.), Mol. Insect Sci. Plenum. Press, New York.

SCHMIDT-CAPELLA, I. C.; HARTFELDER, K. 1998. Juvenile hormone effect on DNA synthesis and apoptosis in caste-specific differentiation of the larval honey bee (Apis mellifera L.) ovary. J. Insect Physiol. 44, 385 - 391.

SEEHUUS, S. C.; NORBERG, K.; GIMSA, U.; KREKLING, T.; AMDAM, G. V. 2006. Reproductive protein protects functionally sterile honey bee workers from oxidative stress. Proc. Nat. Acad. Sci. USA. 103, 962-967.

SHEEHAN, D.; CASEY, J. P. 1993. Microbial glutathione-S-transferases. Comp. Biochem. Physiol. B 104, 1-6.

SINGH, S. P.; CORONELLA, J. A.; BENES, H.; COCHRANE, B. J.; ZIMNIAK, P. 2001. Catalytic function of Drosophila melanogaster glutathione-S-transferase DmGSTS1-1 (GST-2) in conjugation of lipid peroxidation end products. Eur. J. Biochem. 268, 29122923.

SNODGRASS, R. E. 1956. From germ cells to adults. In: Anatomy of the honey bee. Comstock Publishing Associates. Cornell University Press, London.

TELFER, W. H.; KUNKEL, J. G. 1991. The function and evolution of insect storage hexamers. Ann. Rev. Entomol. 36, 205-228. 
TOBA, G.; AIGAKI, T. 2000. Disruption of the microsomal glutathione-S-transferase-like gene reduces lifespan of Drosophila melanogaster. Gene 253, 179-187.

TOUNG, Y.; HSIEH, T. S.; TU, C. P. 1990. Drosophila glutathione-S-transferase 1-1 shares a region of sequence homology with the maize glutathione-S-transferase III. Proc. Natl. Acad. Sci. USA. 87, 31-35.

TRAUTMANN, K. H.; MASNER, P.; SCHULER, A.; SUCHI, M.; WIPF, H. K. 1974. Evidence of the JH methyl (20E, 6E-10,11-epoxy-3,7,11-trimethyl-2,6-dodecadienoate (JHIII) in insects of 4 orders. Z. Naturforsh 29c, 161-168.

VUILLEUMIER, S. J. 1997. Bacterial glutathione-S-transferases: what are they good for? J. Bacteriol. 179, 1431-1441.

WANG, Z.; HAUNERLAND, N. H. 1994. Receptor-mediated endocytosis of storage proteins by fat body of Helicoverpa zea. Cell Tissue Res. 278, 107-115.

WILlOUGHBY, L.; CHUNG, H.; LUMB, C.; ROBIN, C.; BATTERHAM, P.; DABORN, P. J. 2006. A comparison of Drosophila melanogaster detoxification gene induction responses for six insecticides, caffeine and phenobarbital. Insect Biochem. Mol. Biol. 36, 934-942.

WILLOUGHBY, L.; BATTERHAM, P.; DABORN, P. J. 2007. Piperonyl butoxide induces the expression of cytochrome P450 and glutathione-S-transferase genes in Drosophila melanogaster. Pest Manag. Sci. 63, 803-808.

WINSTON, M. L. 2003. A Biologia da Abelha. Ed. Magister LTDA, Porto Alegre.

WHO - WORLD HEALTH ORGANIZATION. 2001. Pyriproxyfen-Acute contact and oral toxicity tests with honey bees, Apis mellifera. 1-19.

WU, M. C.; LU, K. H. 2008. Juvenile hormone induction of glutathione-S-trasnferase activity in the larval fat body of the common cutworm, Spodoptera litura (Lepidoptera: Noctuidae). Arch. Insect Biochem. Physiol. 68, 232-240. 
YOUNG, R. G.; ROBINSON, G. E. 1983. Age and oxygen toxicity related fluorescence in the honey bee thorax. Exp. Gerontol. 18, $471-447$.

YU, S. J. 1996. Insect glutathione-S-transferase. Zool. Stud. 35, 9-19.

ZHANG, X.; DONG, F.; REN, J.; DRISCOLL, M. J.; CULVER, B. 2005. High dietary fat induces NADPH oxidase-associated oxidative stress and inflammation in rat cerebral cortex. Exper. Neurol. 191, 318-325.

ZITNAN, D.; ADAMS, M. E. 2005. Neuroendocrine Regulation of Insect Ecdysis. In: GILBERT, L. I.; IATROU, K.; GILL, S. (Eds.), Comprehensive Molecular Insect Science, vol. 4. Elsevier Press, Oxford.

ZITNAN, D.; KIM, Y. J.; ZITNANOVÁ, I.; ROLLER, L.; ADAMS, M. E. 2007. Complex steroid-peptide-receptor cascade controls insect ecdysis. Gen. Comp. Endocrinol. 153, $88-96$.

ZUFELATO, M. S.; BITONDI, M. M. G.; SIMÕES, Z. L. P.; HARTFELDER, K. 2000. The juvenile hormone analog pyriproxyfen affects ecdysteroid-dependent cuticle melanization and shifts the pupal ecdysteroid peak in the honey bee (Apis mellifera). Arthrop. Struct. \& Develop. 29, 111-119. 
APÊNDICE 


\section{APÊNDICE 1}

Apêndice 1 - Massa molecular das proteínas preditas dos genes GSTs.

\begin{tabular}{cc}
\hline Proteína Predita & Massa Molecular (kDa) \\
GSTS1 & 23,76 \\
GSTS2 & 17,7 \\
GSTS3 & 12,2 \\
GSTS4 & 23,60 \\
GSTD1 & 25,16 \\
GSTO1 & 27,98 \\
GSTT1 & 27,21 \\
GSTZ1 & 24,80 \\
GSTmic1 & 17,12 \\
GSTmic2/3 & 17,55 \\
\hline
\end{tabular}




\section{APÊNDICE 2}

A

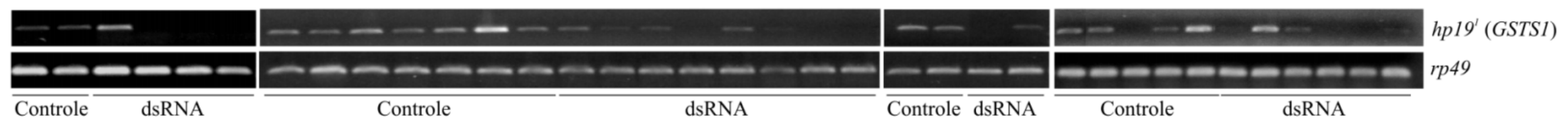

B

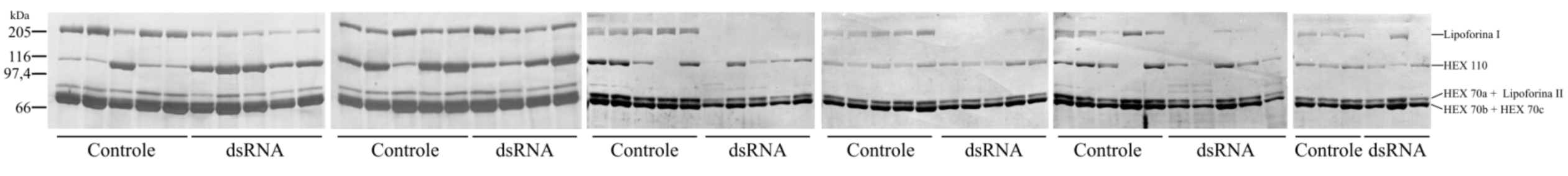

C

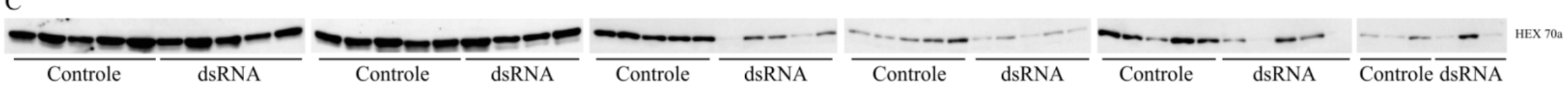

Apêndice 2 - Efeito do dsRNA para silenciamento do gene $h p 19^{1}$ (GSTS1) sobre o teor de hexamerinas HEX 70a na hemolinfa. A) Knockdown da expressão de hp19 (GSTS1) em larvas alimentadas com $15 \mu \mathrm{g}$ de dsRNA. Controles: larvas de idade correspondente que não receberam dsRNA no alimento. RT-PCR semiquantitativa: transcrição reversa e amplificação do cDNA, seguida de eletroforese em gel de agarose corado com brometo de etídeo. O gene de expressão constitutiva, rp49, foi utilizado como normalizador da RT-PCR. B) SDS-PAGE para detecção de HEX 70a, HEX 70b, HEX 70c e HEX 110 na hemolinfa. C) Western blot para detecção de HEX 70a na hemolinfa. 
